\title{
MEASUREMENT OF VISCOSITY, DENSITY, AND GAS SOLUBILITY OF REFRIGERANT BLENDS IN SELECTED SYNTHETIC LUBRICANTS
}

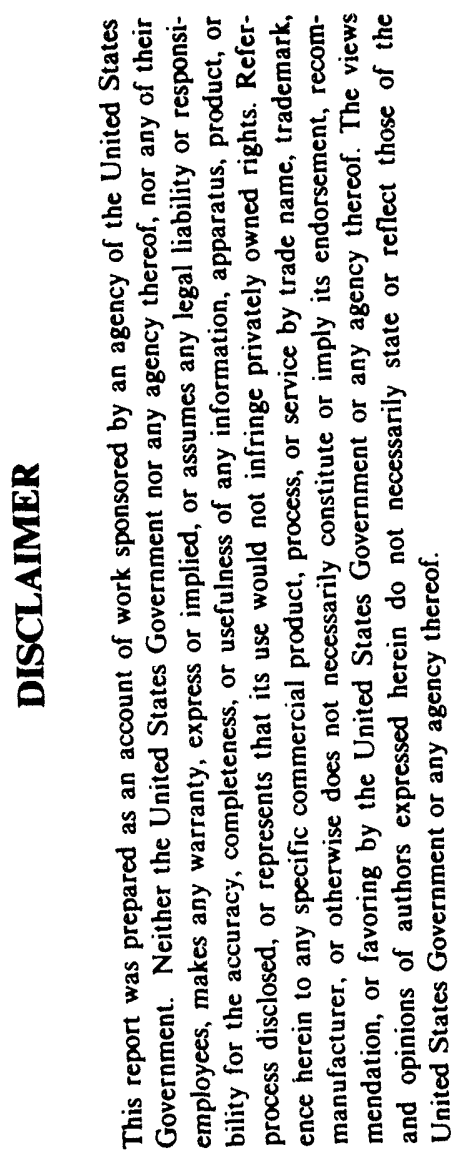

\author{
Quarterly Report \\ October 1 to December 30, 1993 \\ Richard C. Cavestri Ph.D. \\ Imagination Resources, Inc. \\ 5130 Blazer Memorial Parkway \\ Dublin, Ohio 43017
}

January 1994

Prepared for

The Air-Conditioning and Refrigeration Technology Institute

Under

ARTI MCLR Project Number 650-51400: Blends

\begin{abstract}
This project is supported, in whole or in part, by US. Department of Energy grant number DE-FG02-91CE23810: Materials Compatibility and Lubricants Research (MCLR) on CFC-Refrigerant Substitutes. Federal funding supporting this project constitutes $93.67 \%$ of allowable costs. Funding from non-government sources supporting this project consists of direct cost sharing of $6.33 \%$ of allowable costs; and in-kind contributions from the air-conditioning and refrigeration industry.
\end{abstract}




\section{DISCLAIMER}

The U.S. Department of Energy and the air-conditioning industry supporting the Materials Compatibility and Lubricants Research (MCLR) program does not constitute an endorsement by the U.S. Department of Energy or by the air-conditioning and refrigeration industry.

\section{NOTICE}

This report was prepared on account of work sponsored by the United States Government. Neither the United States Government, nor the Department of Energy, nor the Air-Conditioning and Refrigeration Technology Institute (nor any of their employees, contractors, or sub-contractors) makes any warranty, expressed or implied; or assumes any legal liability or responsibility for the accuracy, completeness, or usefulness of any information, apparatus, product or process disclosed; or represents that its use would not infringe privately-owned rights.

\section{COPYRIGHT NOTICE}

(for journal publication submissions)

By acceptance of this article, the publisher and/or recipient acknowledges the right of the U.S. Government and the Air-Conditioning and Refrigeration Technology Institutes, Inc. (ARTI) to retain a non-exclusive, royalty-free license in and to any copyrights covering this paper. 


\begin{abstract}
Liquid/liquid miscibilities of four different 32 ISO VG polyolesters and one alkylbenzene at three concentrations have been determined with five refrigerant blends, including $\mathrm{HC}$ 290. A vapor lubricant equilibrium (VLE) viscosity reduction of 32 ISO VG mineral oil with HCFC-22 has been completed. Composite viscosity reduction information by the fractionate components from R-502 in 32 ISO VG mineral oil has been obtained from $-10^{\circ}$ $\mathrm{C}\left(14^{\circ} \mathrm{F}\right)$ to $125^{\circ} \mathrm{C}\left(257^{\circ} \mathrm{F}\right)$ isotherms. Vapor lubricant equilibrium (VLE) viscosity reduction for 32 ISO VG mixed acid polyolester with HFC-134a and HFC-143a has also been completed. Data is also presented for the viscosity reduction of 32 ISO VG branched acid polyolester by these same refrigerants.
\end{abstract}




\section{CONTENTS}

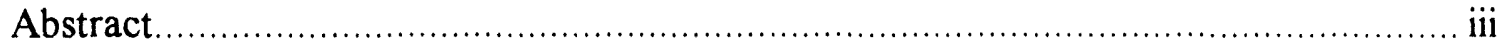

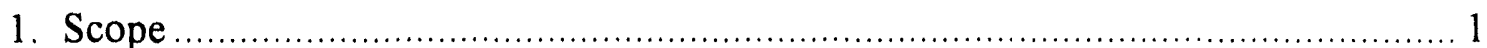

1.1 Statement and Chemical Properties of Lubricants .................................. 2

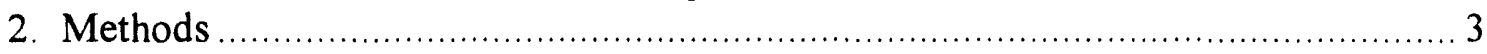

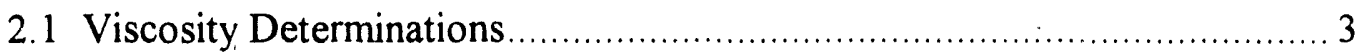

2.2 Refrigerant Blend Sampling ……..................................................

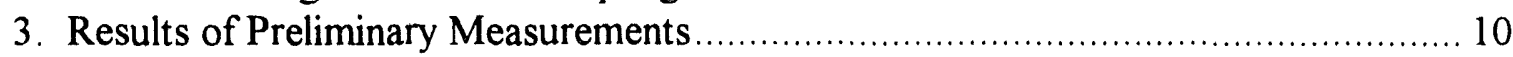

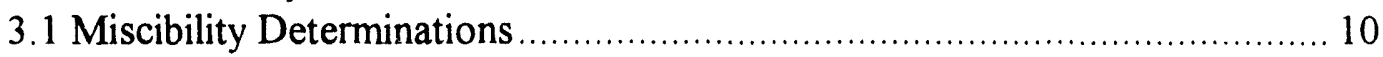

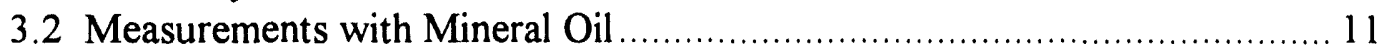

3.2.1 Viscosity of Mineral Oil and HCFC-22 ….............................. 11

3.2.2 Viscosity of 32 ISO VG Mineral Oil with R-502 …................. 15

3.3 Measurements with Polyolesters........................................................ 19

3.3.1 Viscosity of 32 ISO VG Mixed Acid Polyolester with HFC$134 \mathrm{a}$

3.3.2 Viscosity of 32 ISO VG Branched Acid Polyolester with HFC-134a

3.3.3 Viscosity of 32 ISO VG Branched Acid Polyolester with HFC-143a

3.3.4 Viscosity of 32 ISO VG Mixed Acid Polyolester with HFC$143 \mathrm{a}$

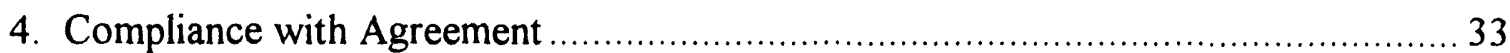

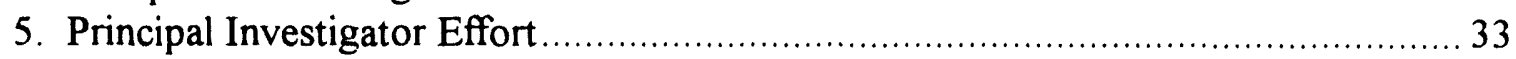

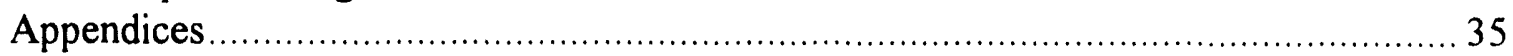

Appendix A: Miscibilities of Refrigerant Blends ......................................... 36

Appendix B: Viscosity and Gas Solubility of 32 ISO VG Mineral Oil at

Various Temperatures with HCFC-22

Appendix C: Viscosity, Solubility, and Gas Fractionation of 32 ISO VG

Mineral Oil at Various Temperatures with R-502 …............................... 49

Appendix D: Viscosity, Density, and Gas Solubility of 32 ISO VG Mixed

Acid Polyolester at Various Temperatures with HFC-134a ........................ 55

Appendix E: Viscosity, Density, and Gas Solubility of 32 ISO VG

Branched Acid Polyolester at Various Temperatures with HFC-134a ...........62

Appendix F: Viscosity, Density, and Gas Solubility of 32 ISO VG

Branched Acid Polyolester at Various Temperatures with HFC-143a

Appendix G: Viscosity, Density, and Gas Solubility of 32 ISO VG Mixed

Acid Polyolester at Various Temperatures with HFC-143a. 


\section{LIST OF FIGURES}

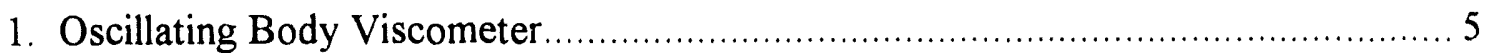

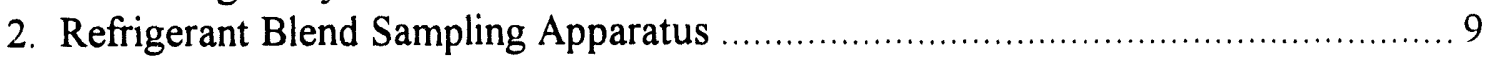

3. Viscosity vs. Temperature: HCFC-22 in 32 ISO VG Mineral Oil....................... 12

4. Viscosity and Pressure at Constant Concentrations: HCFC-22 in 32 ISO VG

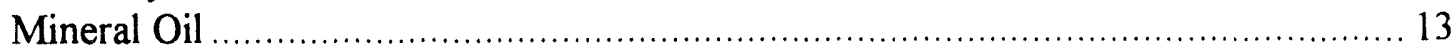

5. Density vs. Temperature: HCFC-22 in 32 ISO VG Mineral Oil ........................... 14

6. Viscosity vs. Temperature: R-502 in 32 ISO VG Mineral Oil .............................. 16

7. Viscosity and Pressure at Constant Concentrations: R-502 in 32 ISO VG

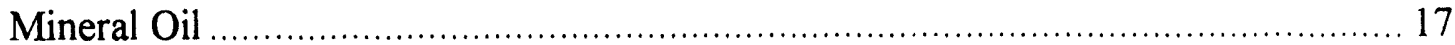

8. Density vs. Temperature: R-502 in 32 ISO VG Mineral Oil.............................. 18

9. Viscosity vs. Temperature: HFC-134a in 32 ISO VG Mixed Acid Polyolester........ 21

10. Viscosity and Pressure at Constant Concentrations: HFC-134a in 32 ISO VG Mixed Acid Polyolester ……................................................................ 22

11. Density vs. Temperature: HFC-134a in 32 ISO VG Mixed Acid Polyolester .........23

12. Viscosity vs. Temperature: HFC-134a in 32 ISO VG Branched Acid Polyolester

13. Viscosity and Pressure at Constant Concentrations: HFC-134a in 32 ISO VG

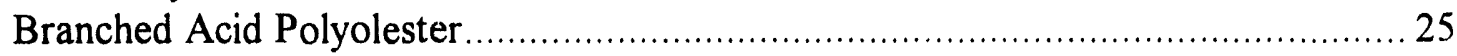

14. Density vs. Temperature: HFC-134a in 32 ISO VG Branched Acid Polyolester ..... 26

15. Viscosity vs. Temperature: HFC-143a in 32 ISO VG Branched Acid Polyolester 27

16. Viscosity and Pressure at Constant Concentrations: HFC-143a in 32 ISO VG Branched Acid Polyolester ..................................................................... 28

17. Density vs. Temperature: HFC-143a in 32 ISO VG Branched Acid Polyolester.... 29

18. Viscosity vs. Temperature: HFC-143a in 32 ISO VG Mixed Acid Polyolester ....... 30

19. Viscosity and Pressure at Constant Concentrations: HFC-143a in 32 ISO VG Mixed Acid Polyolester ........................................................................... 31

20. Density vs. Temperature: HFC-143a in 32 ISO VG Mixed Acid Polyolester ......... 32

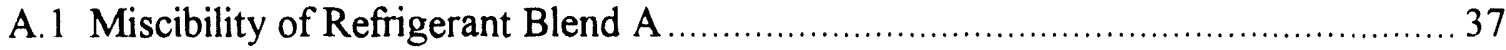

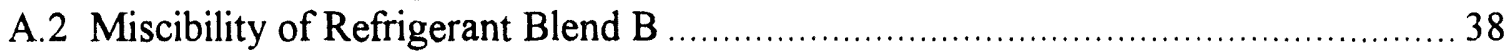

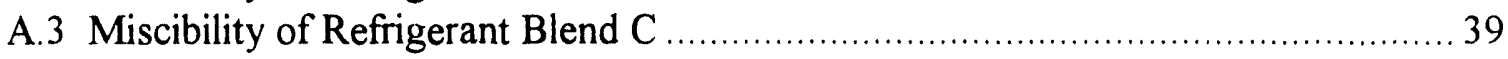

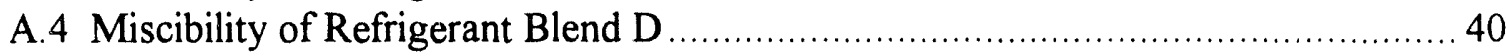

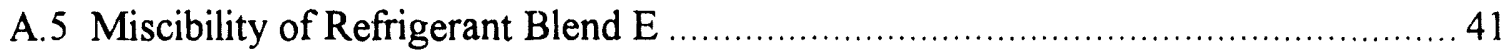

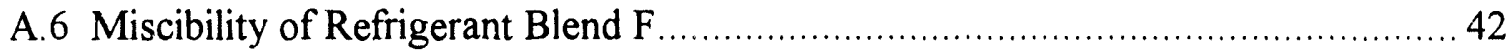

B.1 Viscosity and Gas Solubility of 32 ISO VG Mineral Oil with HCFC-22 at $125^{\circ} \mathrm{C}$

B.2 Viscosity and Gas Solubility of 32 ISO VG Mineral Oil with HCFC-22 at

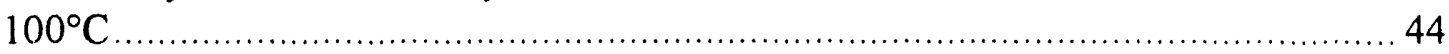

B. 3 Viscosity and Gas Solubility of 32 ISO VG Mineral Oil with HCFC-22 at $80^{\circ} \mathrm{C}$ 
B.4 Viscosity and Gas Solubility of 32 ISO VG Mineral Oil with HCFC-22 at $60^{\circ} \mathrm{C}$

B. 5 Viscosity and Gas Solubility of 32 ISO VG Mineral Oil with HCFC-22 at $40^{\circ} \mathrm{C}$

B.6 Viscosity and Gas Solubility of 32 ISO VG Mineral Oil with HCFC-22 at $20^{\circ} \mathrm{C}$

B.7 Viscosity and Gas Solubility of 32 ISO VG Mineral Oil with HCFC -22 at $0^{\circ} \mathrm{C} \ldots . .47$

B.8 Viscosity and Gas Solubility of 32 ISO VG Mineral Oil with HCFC-22 at $-20^{\circ} \mathrm{C}$

C.1 Viscosity, Solubility, and Gas Fractionation of 32 ISO VG Mineral Oil with $\mathrm{R}-502$ at $125^{\circ} \mathrm{C}$

C. 2 Viscosity, Solubility, and Gas Fractionation of 32 ISO VG Mineral Oil with $\mathrm{R}-502$ at $100^{\circ} \mathrm{C}$

C.3 Viscosity, Solubility, and Gas Fractionation of 32 ISO VG Mineral Oil with $\mathrm{R}-502$ at $70^{\circ} \mathrm{C}$

C. 4 Viscosity, Solubility, and Gas Fractionation of 32 ISO VG Mineral Oil with $\mathrm{R}-502$ at $40^{\circ} \mathrm{C}$

C. 5 Viscosity, Solubility, and Gas Fractionation of 32 ISO VG Mineral Oil with R-502 at $20^{\circ} \mathrm{C}$

C.6 Viscosity, Solubility, and Gas Fractionation of 32 ISO VG Mineral Oil with $\mathrm{R}-502$ at $0^{\circ} \mathrm{C}$

C. 7 Viscosity, Solubility, and Gas Fractionation of 32 ISO VG Mineral Oil with R-502 at $-10^{\circ} \mathrm{C}$

D. 1 Viscosity and Gas Solubility of 32 ISO VG Mixed Acid Polyolester with HFC- $134 \mathrm{a}$ at $125^{\circ} \mathrm{C}$

D. 2 Viscosity and Gas Solubility of 32 ISO VG Mixed Acid Polyolester with HFC-134a at $100^{\circ} \mathrm{C}$

D. 3 Viscosity and Gas Solubility of 32 ISO VG Mixed Acid Polyolester with $\mathrm{HFC}-134 \mathrm{a}$ at $80^{\circ} \mathrm{C}$

D.4 Viscosity and Gas Solubility of 32 ISO VG Mixed Acid Polyolester with $\mathrm{HFC}-134 \mathrm{a}$ at $60^{\circ} \mathrm{C}$

D.5 Viscosity and Gas Solubility of 32 ISO VG Mixed Acid Polyolester with HFC- $134 \mathrm{a}$ at $40^{\circ} \mathrm{C}$

D.6 Viscosity and Gas Solubility of 32 ISO VG Mixed Acid Polyolester with HFC-134a at $20^{\circ} \mathrm{C}$.

D.7 Viscosity and Gas Solubility of 32 ISO VG Mixed Acid Polyolester with $\mathrm{HFC}-134 \mathrm{a}$ at $0^{\circ} \mathrm{C}$

D. 8 Viscosity and Gas Solubility of 32 ISO VG Mixed Acid Polyolester with HFC- $134 \mathrm{a}$ at $-15^{\circ} \mathrm{C}$

D. 9 Viscosity and Gas Solubility of 32 ISO VG Mixed Acid Polyolester with $\mathrm{HFC}-134 \mathrm{a}$ at $-30^{\circ} \mathrm{C}$ 
E. 1 Viscosity and Gas Solubility of 32 ISO VG Branched Acid Polyolester with HFC-134a at $125^{\circ} \mathrm{C}$....

E.2 Viscosity and Gas Solubility of 32 ISO VG Branched Acid Polyolester with $\mathrm{HFC}-134 \mathrm{a}$ at $80^{\circ} \mathrm{C}$.

E. 3 Viscosity and Gas Solubility of 32 ISO VG Branched Acid Polyolester with $\mathrm{HFC}-134 \mathrm{a}$ at $60^{\circ} \mathrm{C}$.

E. 4 Viscosity and Gas Solubility of 32 ISO VG Branched Acid Polyolester with $\mathrm{HFC}-134 \mathrm{a}$ at $40^{\circ} \mathrm{C}$.

E. 5 Viscosity and Gas Solubility of 32 ISO VG Branched Acid Polyolester with HFC-134a at $0^{\circ} \mathrm{C}$.

F.1 Viscosity and Gas Solubility of 32 ISO VG Branched Acid Polyolester with HFC-143a at $125^{\circ} \mathrm{C}$.

F.2 Viscosity and Gas Solubility of 32 ISO VG Branched Acid Polyolester with HFC-143a at $80^{\circ} \mathrm{C}$.

F. 3 Viscosity and Gas Solubility of 32 ISO VG Branched Acid Polyolester with HFC- 143 a at $60^{\circ} \mathrm{C}$.

F. 4 Viscosity and Gas Solubility of 32 ISO VG Branched Acid Polyolester with $\mathrm{HFC}-143$ a at $40^{\circ} \mathrm{C}$.

F. 5 Viscosity and Gas Solubility of 32 ISO VG Branched Acid Polyolester with HFC- 143 a at $20^{\circ} \mathrm{C}$.

F. 6 Viscosity and Gas Solubility of 32 ISO VG Branched Acid Polyolester with HFC-143a at $0^{\circ} \mathrm{C}$.

G.1 Viscosity and Gas Solubility of 32 ISO VG Mixed Acid Polyolester with HFC- $143 \mathrm{a}$ at $125^{\circ} \mathrm{C}$

G.2 Viscosity and Gas Solubility of 32 ISO VG Mixed Acid Polyolester with $\mathrm{HFC}-143 \mathrm{a}$ at $80^{\circ} \mathrm{C}$

G.3 Viscosity and Gas Solubility of 32 ISO VG Mixed Acid Polyolester with $\mathrm{HFC}-143 \mathrm{a}$ at $60^{\circ} \mathrm{C}$

G.4 Viscosity and Gas Solubility of 32 ISO VG Mixed Acid Polyolester with $\mathrm{HFC}-143$ a at $40^{\circ} \mathrm{C}$

G. 5 Viscosity and Gas Solubility of 32 ISO VG Mixed Acid Polyolester with $\mathrm{HFC}-143 \mathrm{a}$ at $20^{\circ} \mathrm{C}$

G.6 Viscosity and Gas Solubility of 32 ISO VG Mixed Acid Polyolester with $\mathrm{HFC}-143 \mathrm{a}$ at $0^{\circ} \mathrm{C}$ 


\section{LIST OF TABLES}

1. Blends with Refrigerant Proportions in Percentages by Weight .......................... 1

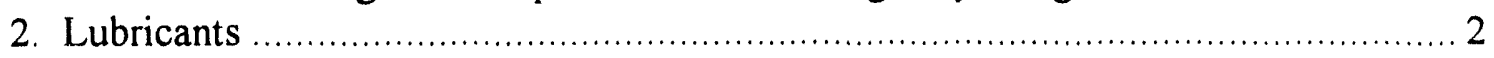

B.1 Raw Data: Viscosity and Gas Solubility of 32 ISO VG Mineral Oil with HCFC-22

C.1 Raw Data: Viscosity, Solubility, and Gas Fractionation of 32 ISO VG Mineral Oil with R-502.

D.1 Raw Data: Viscosity, Density, and Gas Solubility of 32 ISO VG Mixed Acid Polyolester with HFC-134a.

E.1 Raw Data: Viscosity, Density, and Gas Solubility of 32 ISO VG Branched Acid Polyolester with HFC-134a

F.1 Raw Data: Viscosity, Density, and Gas Solubility of 32 ISO VG Branched Acid Polyolester with HFC-143a

G.1 Raw Data: Viscosity, Density, and Gas Solubility of 32 ISO VG Mixed Acid Polyolester with HFC-143a. 


\section{SCOPE}

This study will measure the viscosity, density and solubility of refrigerant/lubricant mixtures using various blended refrigerants. The two lubricants chosen for this study are a fully and partially miscible 32 ISO VG branched acid polyolester and a mixed branched acid 32 ISO VG polyolester. The refrigerant mixtures to be tested are labeled blends $\mathrm{A}$ through $\mathrm{F}$; the components of these blends are listed in Table 1 as percentages by weight. The refrigerant gas equilibrium solubility information shows the fractionation of the individual gases in the lubricants. Mixtures of lubricants with the individual gases that make up the refrigerant mixtures (HFC-32, HFC-125, HFC-134a, HFC-143a) will also be studied.

Table 1. Blends with Refrigerant Proportions in Percentages by Weight

\begin{tabular}{|c|c|c|c|c|c|}
\hline Blenda & $11 \times c+32 \%$ & $\operatorname{arcc} 125 \%$ & $\mathrm{miC} 134 . \%$ & 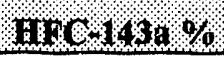 & $1 \mathrm{nzC} 290 \%$ \\
\hline A & 60 & 40 & & & \\
\hline $\mathrm{B}$ & 30 & & 70 & & \\
\hline $\mathrm{C}$ & 30 & 10 & 60 & & \\
\hline $\mathrm{D}$ & & 44 & 2 & 54 & \\
\hline $\mathrm{E}$ & 20 & 55 & 20 & & 5 \\
\hline $\mathrm{F}$ & & 45 & & 55 & \\
\hline
\end{tabular}

The miscibilities of these refrigerant mixtures with five different lubricants were determined so that the two lubricants (a 32 ISO VG branched acid polyolester and a mixed branched acid 32 ISO VG polyolester) used for further testing could be selected. Viscosity determinations were conducted only with mixtures C, D, and F. In order to provide a basis for comparing viscosity, gas solubility, and density, evaluations of HCFC22 and R-502 with a 32 ISO VG mineral oil are included. 
Table 2. Lubricants

\begin{tabular}{|c|c|c|c|c|}
\hline Flud & Name . & Manufacturer & Type & Trademark? \\
\hline A & Icematic SW32 & Castrol & $\begin{array}{c}\text { Branched Acid } \\
\text { Polyolester }\end{array}$ & $\begin{array}{c}\text { Registered } \\
\text { Trademark }\end{array}$ \\
\hline B & Emery 2927a & Henkel, limery Group & $\begin{array}{c}\text { Branched Acid } \\
\text { Polyolester }\end{array}$ & $\begin{array}{c}\text { Registered } \\
\text { Trademark }\end{array}$ \\
\hline C & RL-32S & $\begin{array}{c}\text { ICI Chr micals and } \\
\text { Pol mers, Ltd }\end{array}$ & Mixed Acid Polyolester & $\begin{array}{c}\text { Registered } \\
\text { Trademark }\end{array}$ \\
\hline D & Artic EAL 224R & Mobil & Mixed Acid Polyolester & $\begin{array}{c}\text { Registered } \\
\text { Trademark }\end{array}$ \\
\hline E & Shrieve Zerol 150 & Shrieve Chemical & Alkylbenzene & $\begin{array}{c}\text { Registered } \\
\text { Trademark }\end{array}$ \\
\hline F & Suniso 3GS & Witco Corporation & $\begin{array}{c}\text { Naphthenic Mineral } \\
\text { Oil }\end{array}$ & $\begin{array}{c}\text { Registered } \\
\text { Trademark }\end{array}$ \\
\hline
\end{tabular}

\subsection{Statement and Chemical Properties of Lubricants}

The viscosity and liquid/liquid miscibility of lubricants with refrigerants depend on the composition of the lubricants. However, because the lubricants and pentarerythritol poloylesters used in this study are proprietary formulations, information about their specific structural properties, including alcohol type and the stochiometry of the carboxylic acids used in synthesis, remains with the manufacturer. As a result, only the miscibility and viscosity differences between the polyolesters are reported. 


\section{METHODS}

\subsection{Viscosity Determinations}

The method used in this study is similar to that by Albright (1956-59), Little (1956) and Parmelee (1964.) These authors use the gas equilibrium concept -- the saturation of the liquid with vapor -- to study the viscosity reduction of hydrocarbon refrigeration oils in refrigerant gases. In conjunction with the gas equilibrium approach, this study uses temperature and pressure limitations to determine refrigerant gas concentrations.

Viscosity and density are determined accurately by a fourth generation viscometer (Figure 1), which was taken from a report by Nissen. This viscometer system consists of an oscillating body device enclosed in a low volume pressure tube. The active part of this system is a solid oscillating cylinder made of highly polished stainless steel; this is connected to a precisely thermostatted spring inside a stainless steel pipe. An external electromagnet causes the cylindrical bob to oscillate. The decrement of any solution in the viscometer can be determined by measuring the rate of sinusoidal decay. A quick decay represents a high viscosity; a slow decay, a low one. The viscosity of the solution can be determined from the decrement and density.

This viscometer allows a wide range of viscosity determinations $(.10$ to $1800 \mathrm{cP})$ to be made with a single oscillating bob. The viscosity of polyolester blends $\mathrm{B}$ and $\mathrm{C}$, as well as 32 ISO VG mineral oil were measured; the standards used were water and certified standard test fluids (NIST traceable). These standards are calibrated from $-25^{\circ} \mathrm{C}$ to $125^{\circ} \mathrm{C}$ and are reported in both $\mathrm{cP}$ and $\mathrm{cSt}$ values. The readability of the viscometer is $0.06 \mathrm{cP}$. The density of the oils is also reported. The wide temperature range of various calibration oils results in a significant overlap that serves as an internal standard and self check. For low viscosity solutions, the difference between standards is $\pm 0.1 \%$ for low viscosity solutions; this increases to $\pm 1.5 \%$ for high viscosity solutions.

The bob used to determine viscosity can be used to determine density as well.. By observing the position changes of the bob, density can be determined to within 0.0005 $\mathrm{g} / \mathrm{ml}$. Determining consistent density at constant temperature and constant pressure is a very accurate method of measuirng fluid consistency. Accurate density measurements allow the calculation of centistokes (cSt) from centipoise (cP). The density range of the instrument is calibrated with known, readily available pure fluids that are dried over a 
molecular sieve prior to use; this provides a straight calibration line for density at specified temperatures. The precision of this determination is $\pm 0.3 \%$

The fluid refrigerant mixture is pumped from the bottom of the viscometer and sprayed into the refrigerant vapor space at specific pressures and temperatures. Consequently, density may be monitored for equilibrium conditions, the decrement may be measured, and the viscosity may be calculated. Before the fluid is sampled, it is visually examined several times to determine that true solution conditions are present. The fluid sample is then drawn through a very low volume capillary line $(380 \mu l)$ into a deeply evacuated, lightweight glass sampling bulb where a total charge is retained. The ratio of gas to liquid oil (percentage by weight) may then be calculated. The concentration measurement is reproducible within $\pm 0.5 \%$ by weight at a given isothermal pressure test point. Sampling the refrigerant lubricant mixture at each isothermal pressure test point is essential to the measurement technique used in this study. 
Figure 1. Oscillating Body Viscometer

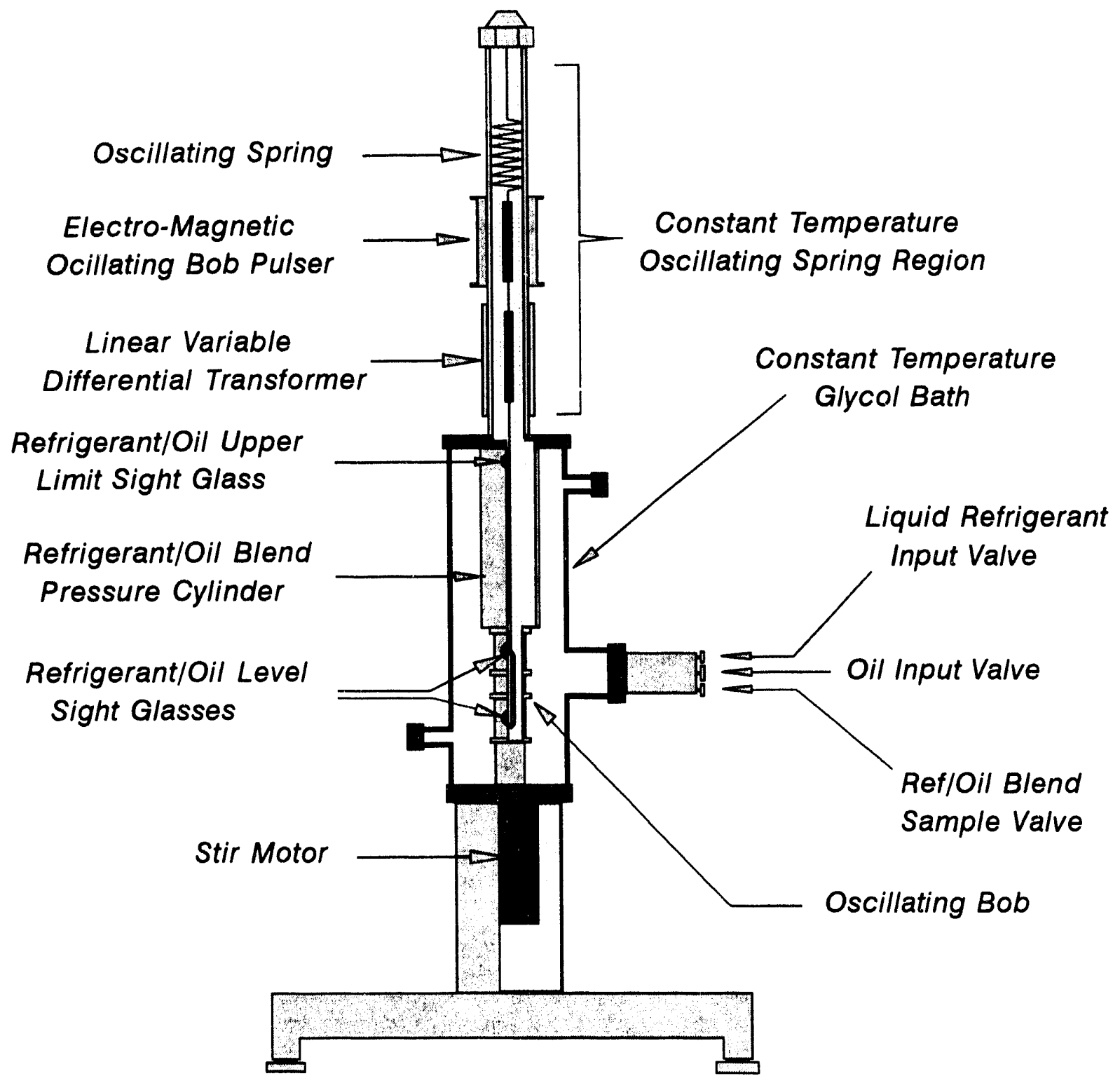


The solubility ranges of refrigerant/lubricant combinations may be inconsistent. For example, the viscometer does not allow the kind of immiscibility conditions that could occur in a low temperature pressure cell containing liquid refrigerant and a partially immisible lubricant. According to the principles of gas equilibrium, forced saturation with liquefied gas is required to produce immiscible layers. Oil may be kept saturated with gas at a specific pressure and temperature by accurately monitoring the gas pressure and keeping it at or below the saturation pressure. For oils that are nearly infinitely miscible, liquid refrigerant can be added to the viscometer under pressure, and fluid properties can be measured for viscosity, density, pressure and refrigerant concentration. Measurements are taken when the oil is saturated with refrigerant gas.

Unless there is a zero void space in a pressurized viscometer cell, the refrigerant-oil pair combinations will change. For example, a fluid with $6.6 \%$ refrigerant by weight at $100^{\circ} \mathrm{C}$ $\left(212^{\circ} \mathrm{F}\right)$ will have a refrigerant concentration almost three times greater $(22.0 \%)$ when it is cooled to $10^{\circ} \mathrm{C}\left(50^{\circ} \mathrm{F}\right)$ inside a closed system (like a viscometer) which has available gas space. When refrigerant blends are used, the composition of the gas in the vapor space of the viscometer is maintained equal to that of the pure refrigerant blend. The fractionation of the mixed gases is determined at every temperature and pressure. Samples of the fluid/refrigerant mixture are collected to determine the percent refrigerant by weight in the fluid. The ratio of gases is determined by gas chromatography, as stated in Section 2.2 .

The fluid measurement portion of the viscometer is equipped with two high temperature and pressure sight glasses directly adjacent to the suspended stainless steel solid cylinder. Through the upper sight glass, the solution is continually monitored for the formation of any immiscible particulates or haze of the fluid and refrigerant. The observer can ensure that the viscorneter is charged with enough fluid to completely cover the bob. The lower sight glass is adjacent to the gas introduction port and to the oil sampling port. The third sight glass, located at the top of the vapor space directly adjacent to the pump exit, allows observation of the foaming qualities of the lubricant and lets the observer guarantee that the mixed system is always at the stated measurement temperature.

For the best reproducible method, pressure is measured with a Bourdon tube gauge with a 660-degree double-helix display. This temperature-compensated gauge is calibrated with both gas and liquid, is accurate to \pm 0.2 psia and is traceable to NIST standards. Vapor pressure is measured at equilibrium, when the soluble gases are responsible for the fluid 
properties. Since the gas content of the fluid is measured, the amount of gas contained in the Bourdon tube is irrelevant.

Density, viscosity, and vapor pressure are always measured under isothermal conditions. The viscometer temperature is maintained by a circulating constant temperature glycol bath controlled by a Platinum RTD $\left( \pm 0.1^{\circ} \mathrm{C}\right)$ microprocessor. The RTD probe is mounted at the surface of the viscometer tube inside the liquid bath. The other temperature zones are controlled by electric heaters, using a microprocessor controller $\left( \pm 0.1^{\circ} \mathrm{C}\right)$ with type "J" thermocouples.

Oil is pumped into the viscometer by a magnetically coupled impeller located in the pump body and sprayed into a soluble gas vapor space at the top of the viscometer. The pressure and temperature in the instrument can be varied to simulate the lubricant/refrigerant pair conditions that exist in operating compressor systems. Test fluids are degassed at $60^{\circ} \mathrm{C}$ $\left(140^{\circ} \mathrm{F}\right)$ to 20 millitorr for 24 hours and are generally dried to $50 \mathrm{ppm}$. Similarly, the viscometer is evacuated to 20 millitorr for several hours, purged with the refrigerant gas several times, and evacuated. The test oil is then drawn through the oil charging valve and re-evacuated to 20 millitorr. The oil is purged with refrigerant gas and evacuated again. Non-condensable gas content is not allowed to exceed $10 \mathrm{ppm}$ or equivalent to the refrigerant used.

\subsection{Refrigerant Blend Sampling}

After refrigerant/lubricant samples are obtained from the viscometer, the glass container and its rubber stopper are weighed. The glass bulb is placed on the sample input port of the apparatus (Figure 2) with the lower stopcock closed. The upper stopcock is opened and attached to the vacuum pump. The upper stopcock remains open until a sufficient vacuum (30-50 millitorr) has been pulled on the gas chamber. When the upper stopcock is closed, the lowe stopcock is opened. The lower pressure in the gas chamber pulls the refrigerant out of the sample in the glass bulb. To separate the refrigerant from the lubricant, the glass bulb is heated carefully with a propane torch. The lower stopcock is closed within 30 seconds after heating. One minute after the lower stopcock is closed, equilibrium is established.

The ratio of the gases can be determined from the sample of gases drawn off the top oil. A second gas sample is obtained to determine if equilibrium has been established and 
whether the ratio of gases has changed. Gas chromatography is used to analyze the refrigerant sample. Separate measurement studies indicate that more than $80 \%$ of the refrigerant contained in the liquid sampling bulb has been removed. Finally, all remaining traces of refrigerant are removed by heating the bulb to constant weight under vacuum. This was then used for the final measurements of net percentage by weight. 
Figure 2. Refrigerant Blend Sampling Apparatus

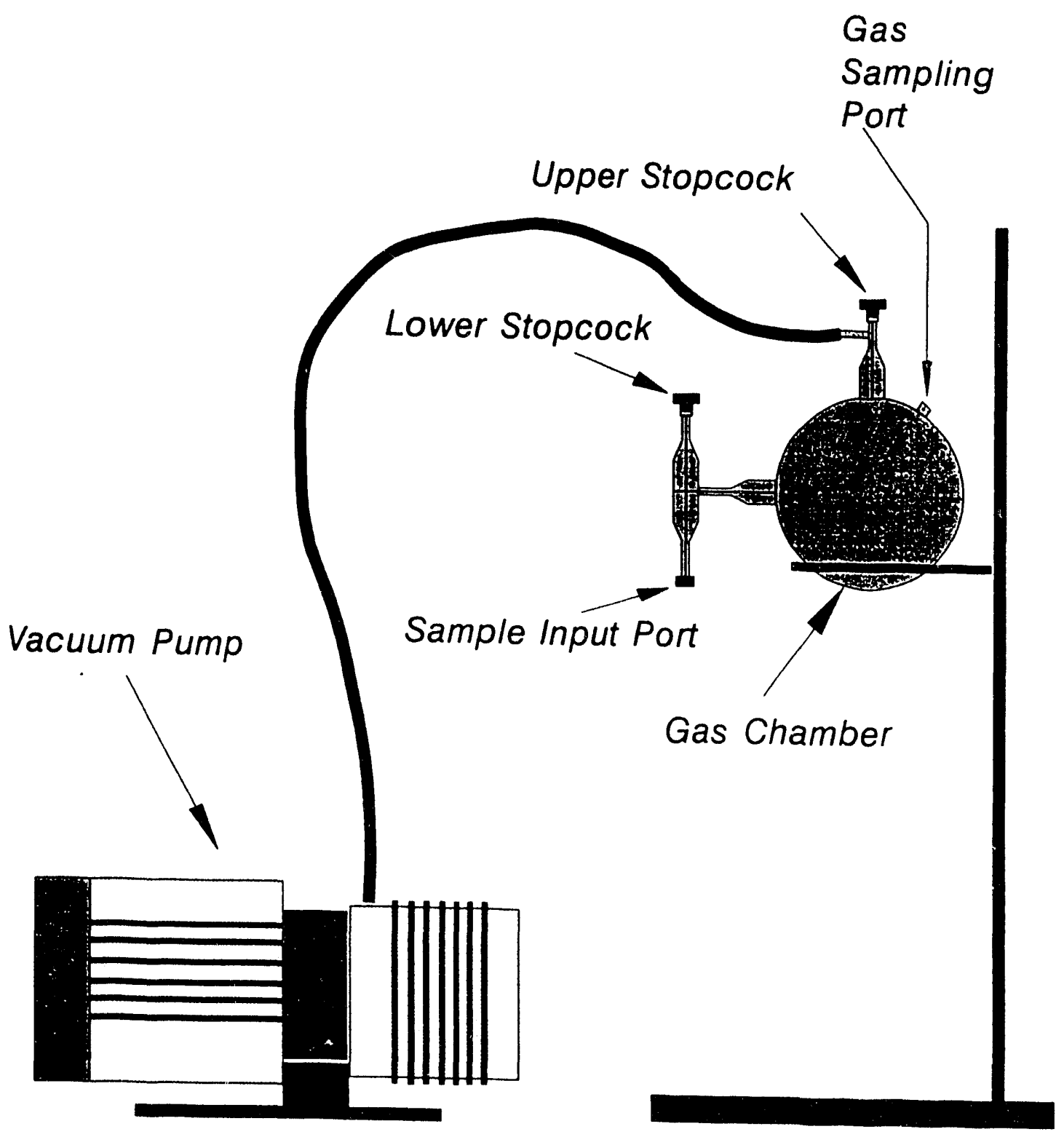




\section{RESULTS OF PRELIMINARY MEASUREMENTS}

In order to select the lubricants to be used in this project, the miscibilities of four different polyolesters and one alkylbenzene with six refrigerant blends have been evaluated. In addition, the density and viscosity of mixtures of pure refrigerant with pure lubricant have been tested; this provides data about the repeatability and accuracy of the viscometer.

\subsection{Miscibility Determinations}

The fluids to be tested for this project were selected based on data about the miscibility of four different polyolesters and one alkylbenzene with six refrigerant blends (Appendix A.)at three different refrigerant/lubricant concentrations. Alkylbenzene is used to determine the miscibility of aromatics. Surprisingly, blend D appears partially miscible, perhaps as a result of lower temperature. This suggests a possibility for good oil return and inverse miscibility at higher temperatures, which indicates undiluted hydrocarbon lubrication.

Levels of immiscibility may significantly effect the fractionation of individual gases at different temperatures and pressures. For example, Lubricant B is a 32 ISO VG branched acid polyolester, believed to be the most miscible type; its very high liquid/liquid miscibility suggests that it will have very little influence on the fractionation of the various gases that compose refrigerant blends. Lubricant $\mathrm{C}$ has been determined to be the least miscible lubricant tested, although its viscosity is close to that of Lubricant B Consequently, Lubricant $\mathrm{C}$ was used in this study to verify the impact of partial liquid miscibility on the gas solubility of various gases in refrigerant blends. Lubricants $\mathrm{A}$ and $\mathrm{D}$, which are in the intermediate range of miscibility, could also be used for this. 


\subsection{Measurements with Mineral Oil}

\subsubsection{Viscosity of 32 ISO VG Mineral Oil and HCFC-22}

Appendix B illustrates the isothermal viscosity, density and solubility of HCFC-22 in 32 ISO VG mineral oil. This oil was purchased locally at Grainger Industrial Supply. Isothermal determination provides a snapshot view of refrigerant/lubricant solubility knees, which are unique to each refrigerant/lubricant combination. Solubility knees become apparent as the concentration of refrigerants approaches the critical phase of refrigerant/refrigerant gas solutions. The lowest temperature for which visccsities were determined is $-20^{\circ} \mathrm{C}$. Viscosity measurements at $-40^{\circ} \mathrm{C}$ were attempted without success; when refrigerant concentrations exceeded $9 \%$, the fluid became immiscible. Figure 3 presents viscosity as a function of temperature, and includes isobaric pressure lines. Figure 4 presents a modified "Daniel Plot" that shows viscosity and pressure at constant concentration as a function of temperature. Figure 5 shows density as a function of temperature at constant concentration. The raw data tables in Appendix B (Table B.1) present density values. 


\section{Viscosity vs Temperature HCFC-22 in 32 ISO VG Mineral Oil \\ Figure 3}

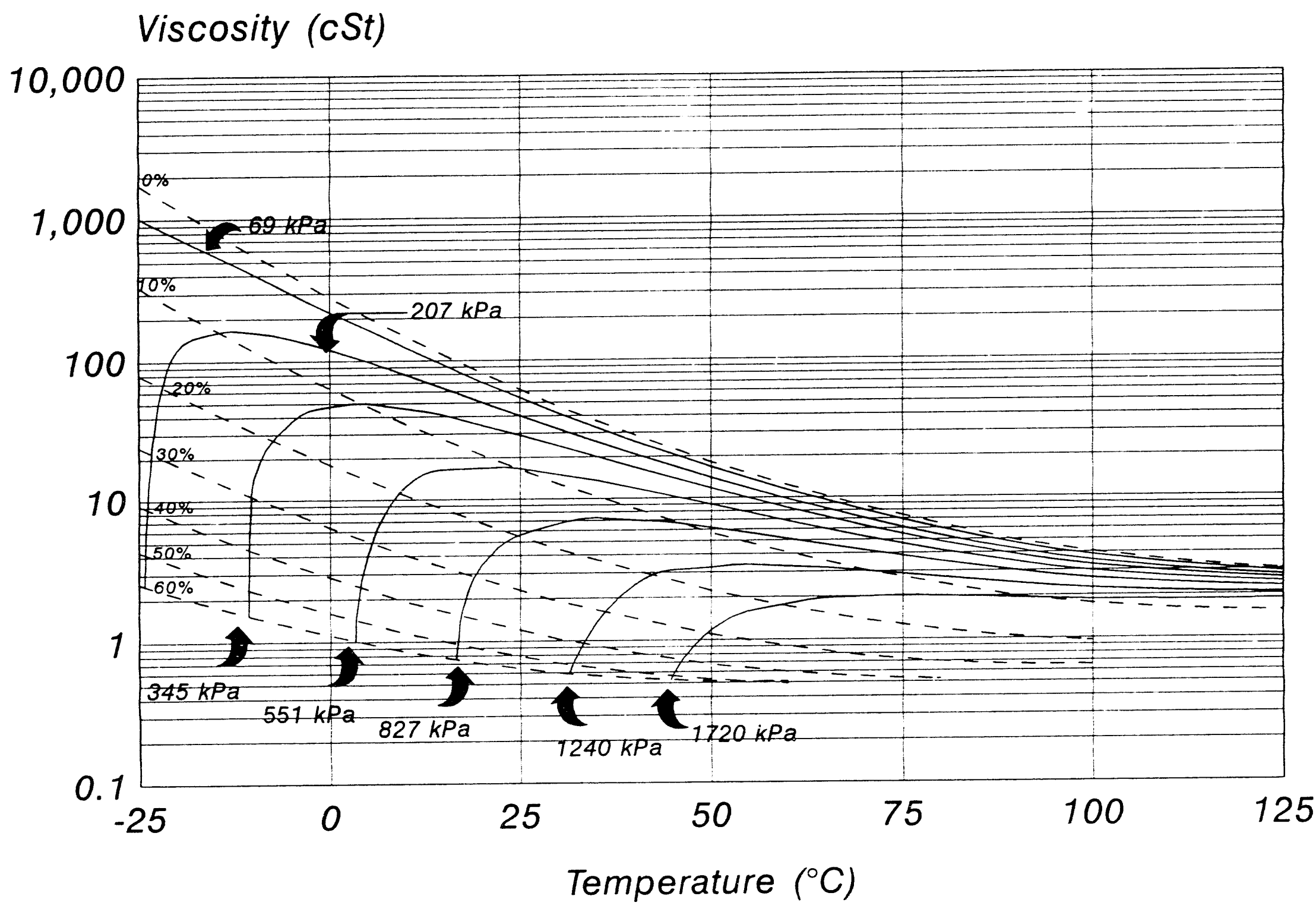




\section{Viscosity and Pressure at Constant Concentrations}

HCFC-22 in 32 ISO VG Mineral Oil

Figure 4

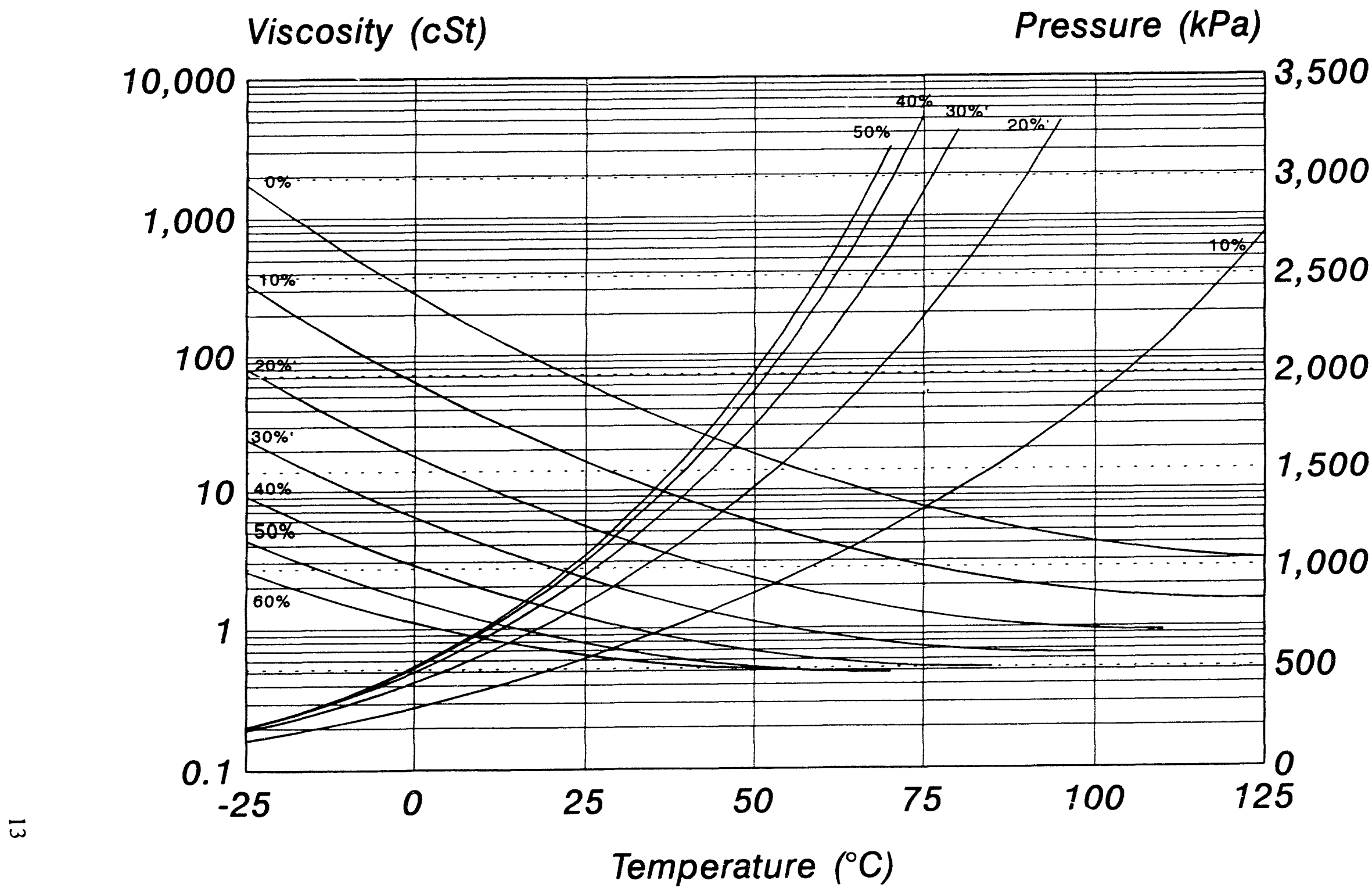




\section{Density vs Temperature}

HCFC-22 in 32 ISO VG Mineral Oil

Figure 5

\section{Density $(\mathrm{g} / \mathrm{mL})$}

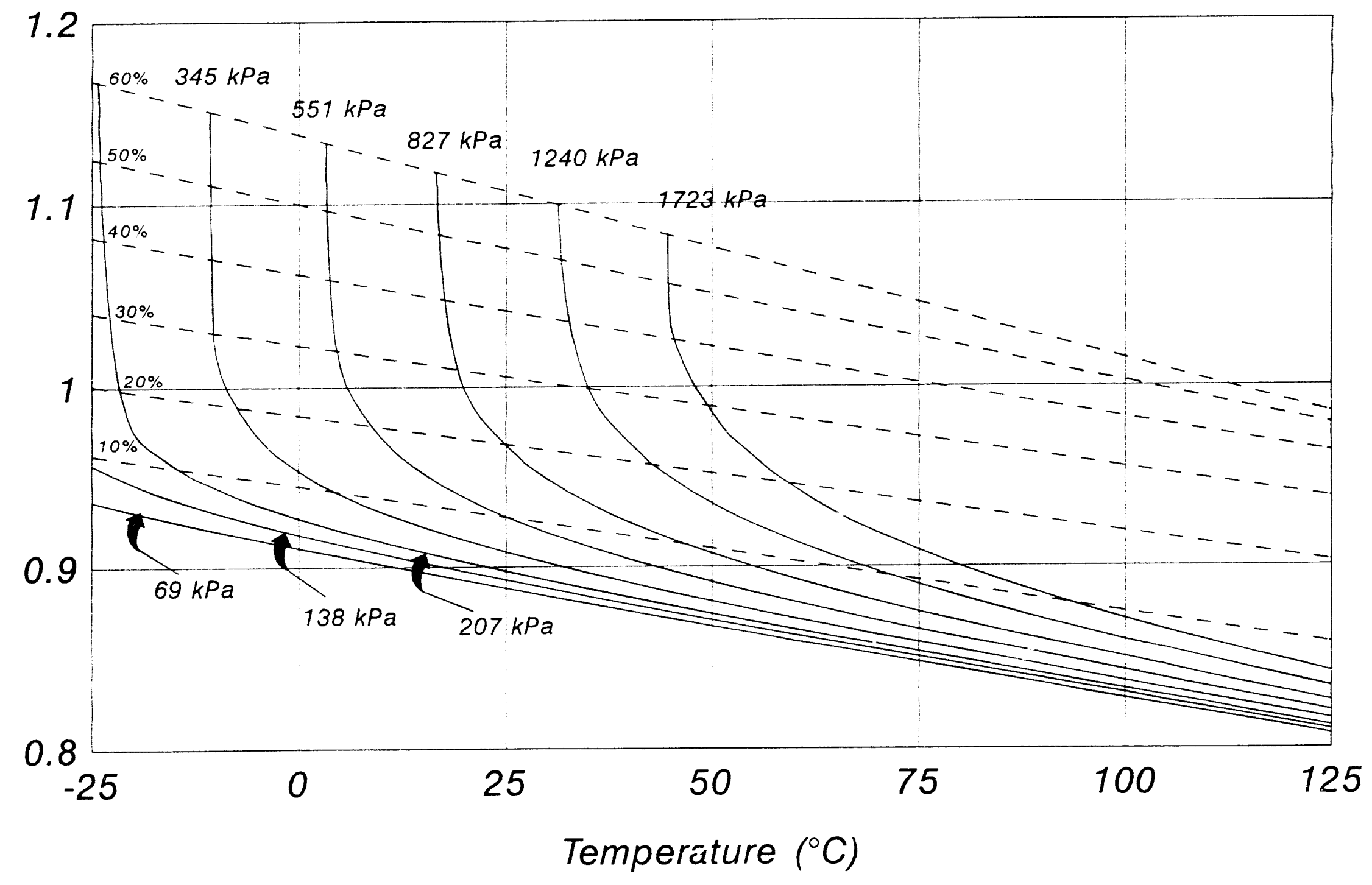




\subsubsection{Viscosity of 32 ISO VG Mineral Oil with R-502}

Appendix C shows the isothermal viscosity, density, and solubility of R-502 in 32 ISO VG mineral oil. Each isothermal plot shows the fractionation of R-502 as percentage R-22 of the total gas in solution. The lowest temperature at which viscosity was determined is $10^{\circ} \mathrm{C}$ : the highest is $125^{\circ} \mathrm{C}$ and 500 psia. At each test temperature and pressure, mixed refrigerant gas is purged through the lubricant until the fractionated components reach equilibrium. The equilibrium is maintained by me.king this refrigerant gas above the lubricant equal to the proportion of the mixed lubricant and refrigerant. The percent concentration of the total refrigerant represents the total of both gases that are soluble in the fluid at that pressure and temperature. Figure 6 presents viscosity as a function of temperature and includes isobaric pressure lines. Figure 7 presents a modified "Daniel Plot" that shows viscosity and pressure at constant concentration as a function of temperature. Figure 8 shows density as a function of temperature at constant concentration. 


\section{Viscosity vs Temperature}

R-502 in 32 ISO VG Mineral Oil

Figure 6

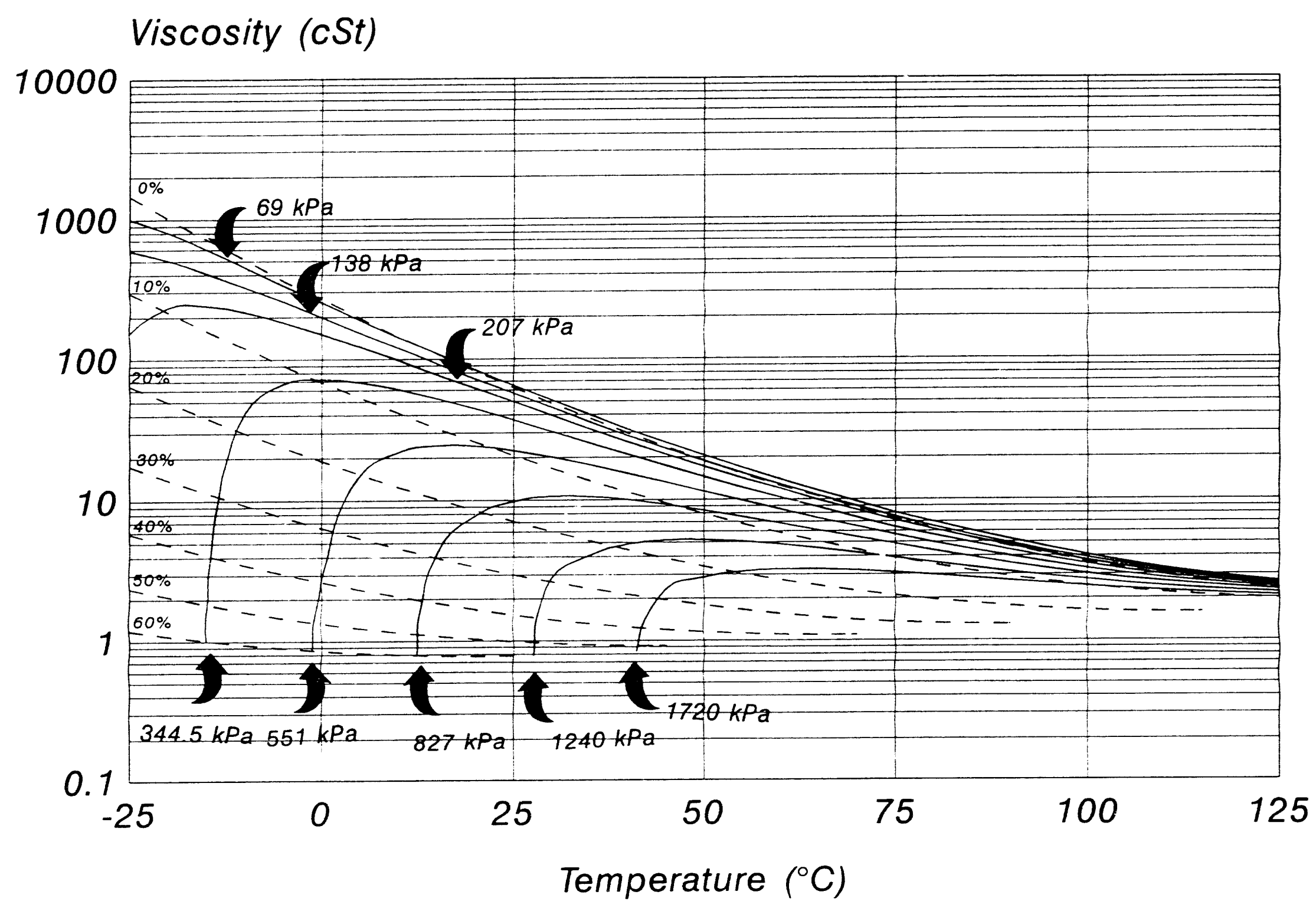




\section{Viscosity and Pressure at Constant Concentrations $R-502$ in 32 ISO VG Mineral Oil \\ Figure 7}

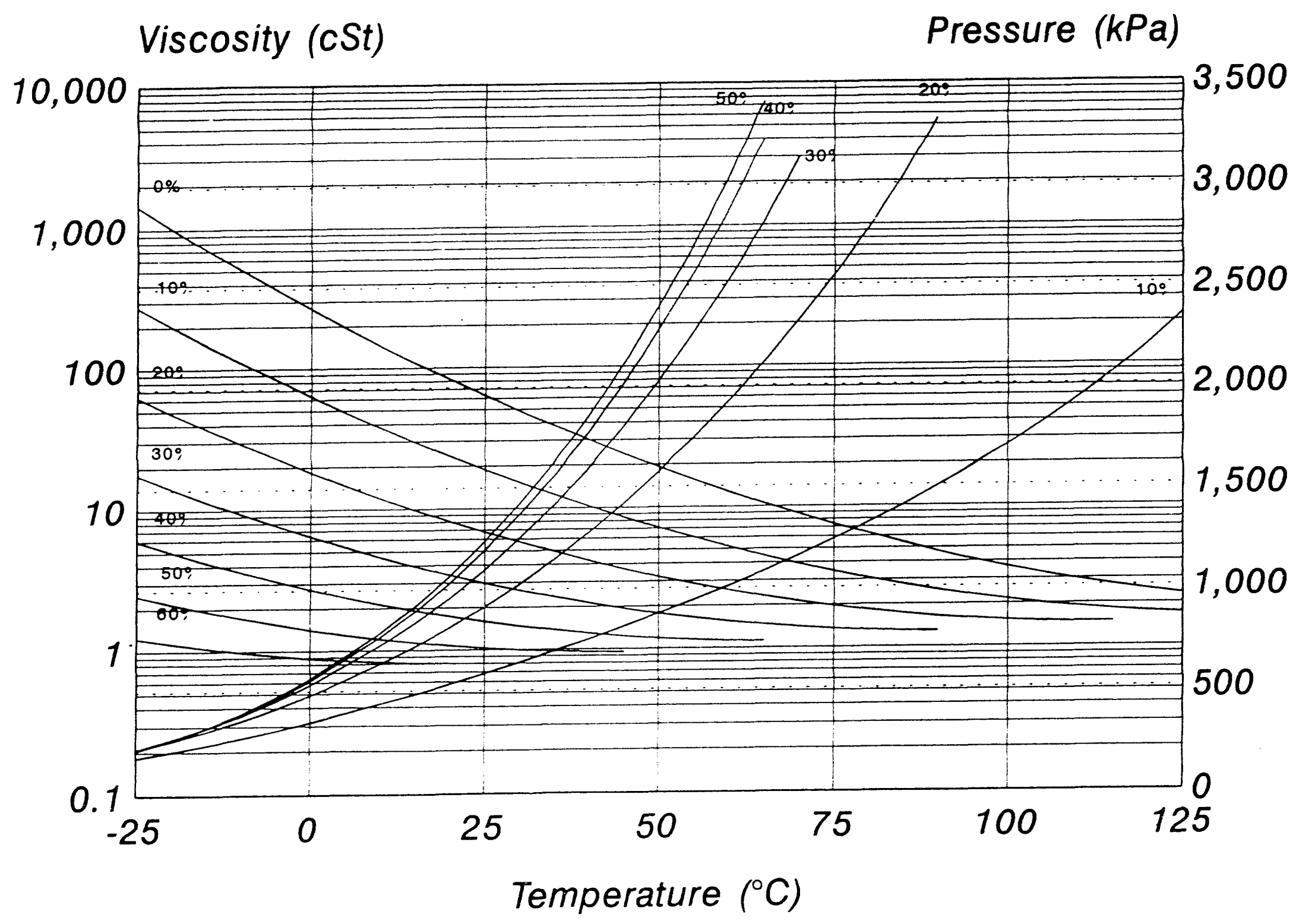



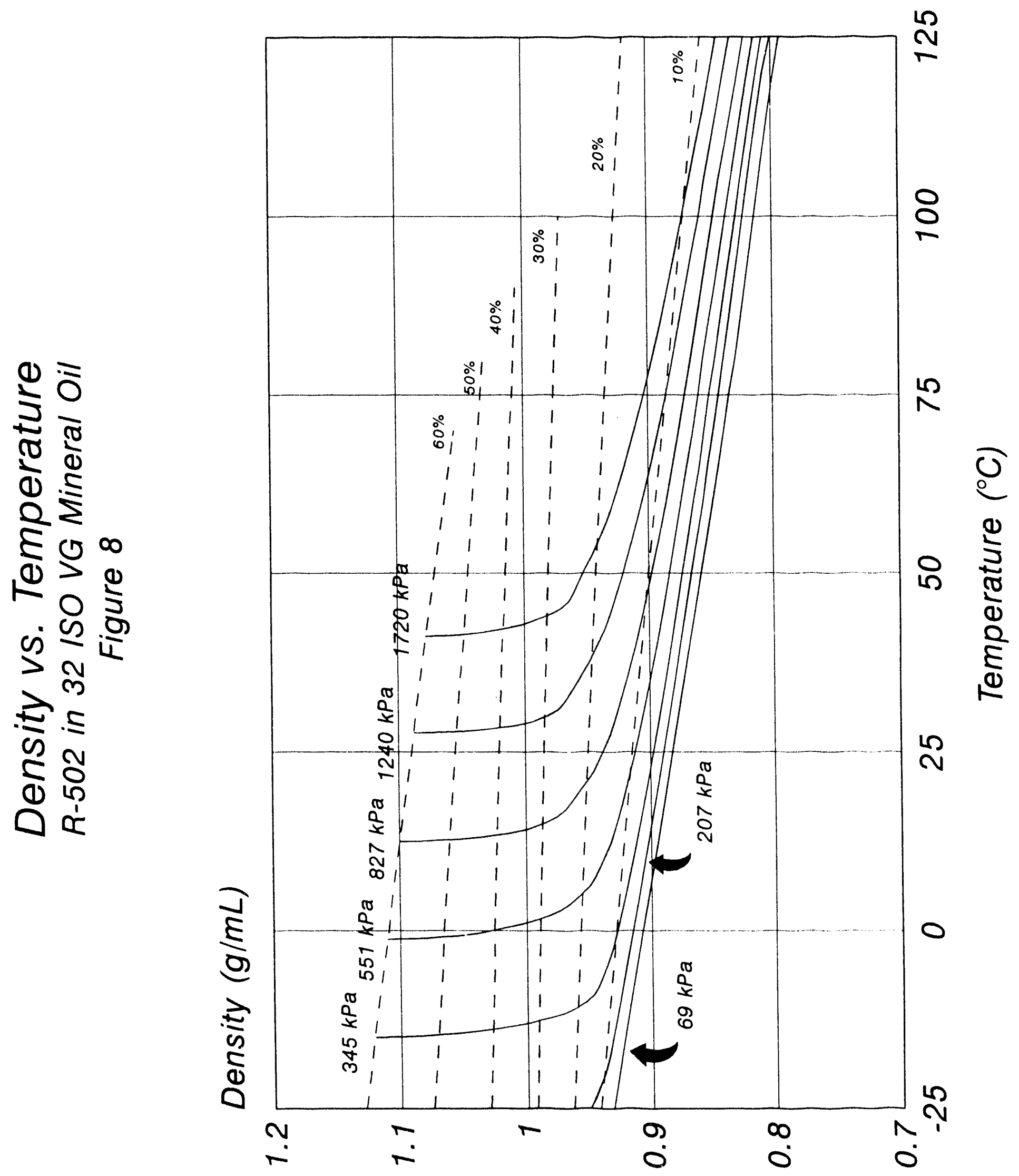


\subsection{Measurements with Polyolesters}

\subsubsection{Viscosity of 32 ISO VG Mixed Acid Polyester with HFC-134a}

Appendix D presents, in Table D.1, the isothermal viscosity, density, and solubility of gaseous HFC-134a in a 32 ISO VG mixed acid polyolester with good miscibility characteristics. Some isothermal curves illustrate reasonably straight viscosity reduction with increasing refrigerant dilution, while some show a characteristic solubility knee. Several viscosity data points were taken; the lowest temperature at which viscosity was measured was $-30^{\circ} \mathrm{C}$. Figure 9 presents viscosity as a function of temperature and includes isobaric pressure lines. Figure 10 presents a modified "Daniel plot" showing viscosity and pressure at constant concentrations as a function of temperature. Figure 11 shows density as a function of temperature at constant concentrations.

\subsubsection{Viscosity of 32 ISO VG Branched Acid Polyester with HFC-134a}

Appendix E presents, in Table E.1, the isothermal viscosity, density, and solubility of gaseous HFC-134a in a 32 ISO VG branched acid polyolester with good miscibility characteristics. Figure 12 presents viscosity as a function of temperature and includes isobaric pressure lines. Figure 13 presents a modified "Daniel plot" showing viscosity and pressure at constant concentrations as a function of temperature. Figure 14 shows density as a function of temperature at constant concentrations.

\subsubsection{Viscosity of 32 ISO VG Branched Acid Polyester with HFC-143a}

Appendix $F$ presents, in Table F.1, the isothermal viscosity, density, and solubility of gaseous HFC-143a in a 32 ISO VG branched acid polyolester. Five viscosity data points were taken for each temperature. Figure 15 presents viscosity as a function of temperature and includes isobaric pressure lines. Figure 16 presents a modified "Daniel plot" showing viscosity and pressure at constant concentrations as a function of temperature. The $10 \%$ and $20 \%$ concentration lines flatten as the temperature increases. The characteristics of HFC-143a may cause this effect, which is confirmed by the isothermal test points. However, it is not seen with mixed-acid polyolester (see figure 19). Figure 17 shows density as a function of temperature at constant concentrations.

\subsubsection{Viscosity of 32 ISO VG Mixed Acid Polyester with HFC-143a}

Appendix G presents, in Table G.1, the isothermal viscosity, density, and solubility of gaseous HFC-143a in a 32 ISO VG mixed acid polyolester with good miscibility characteristics. Five viscosity data points were taken for each temperature. Figure 18 presents viscosity as a function of temperature and includes isobaric pressure lines. Figure 
19 presents a modified "Daniel plot" showing viscosity and pressure at constant concentrations as a function of temperature. Figure 20 shows density as a function of temperature at constant concentrations. 
Viscosity vs. Temperature

HFC-134a in 32 ISO VG Mixed Acid Polyolester

Figure 9

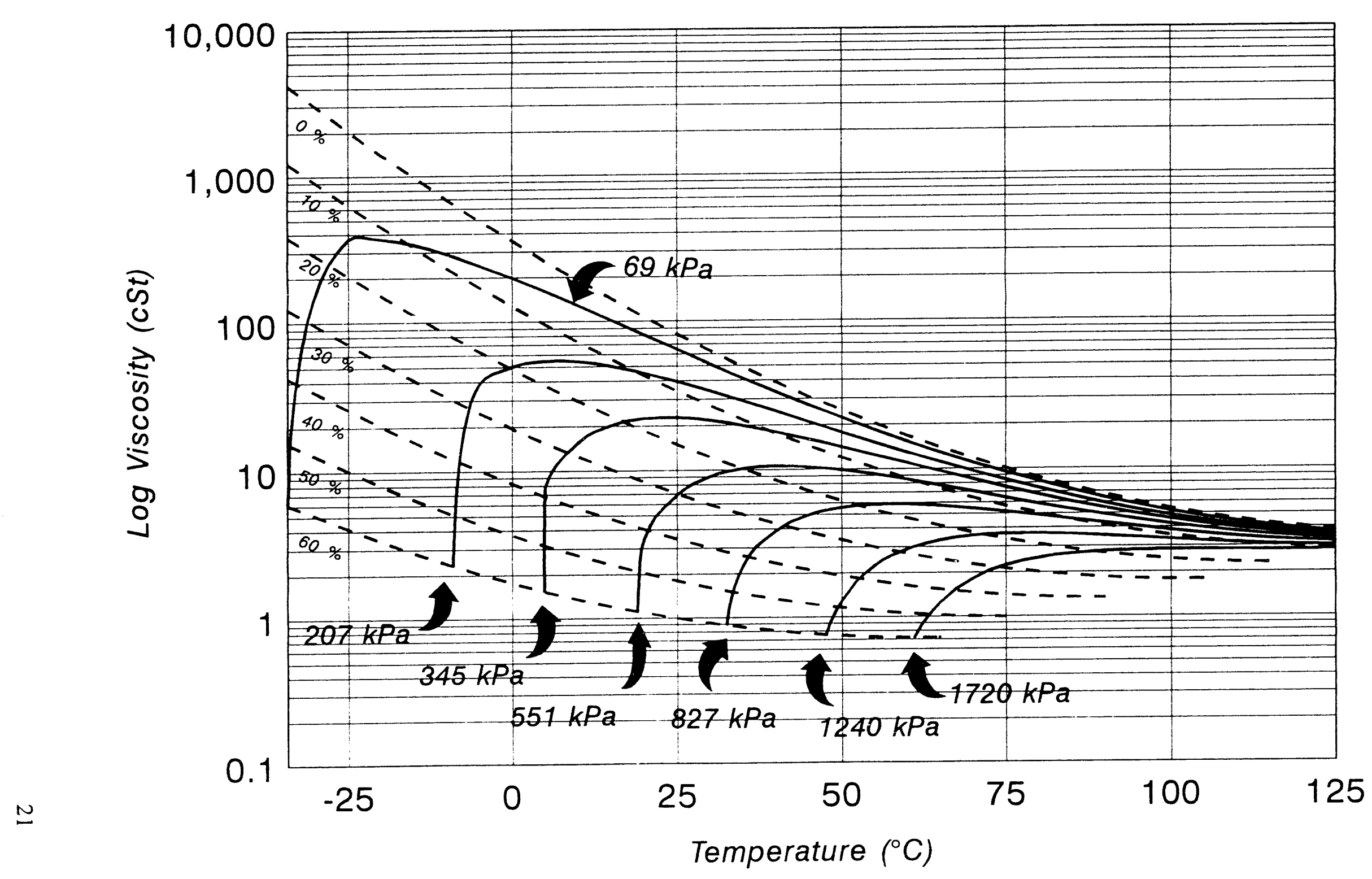


Viscosity and Pressure at Constant Concentrations R-134a in 32 ISO VG Mixed Acid Polyolester

Figure 10

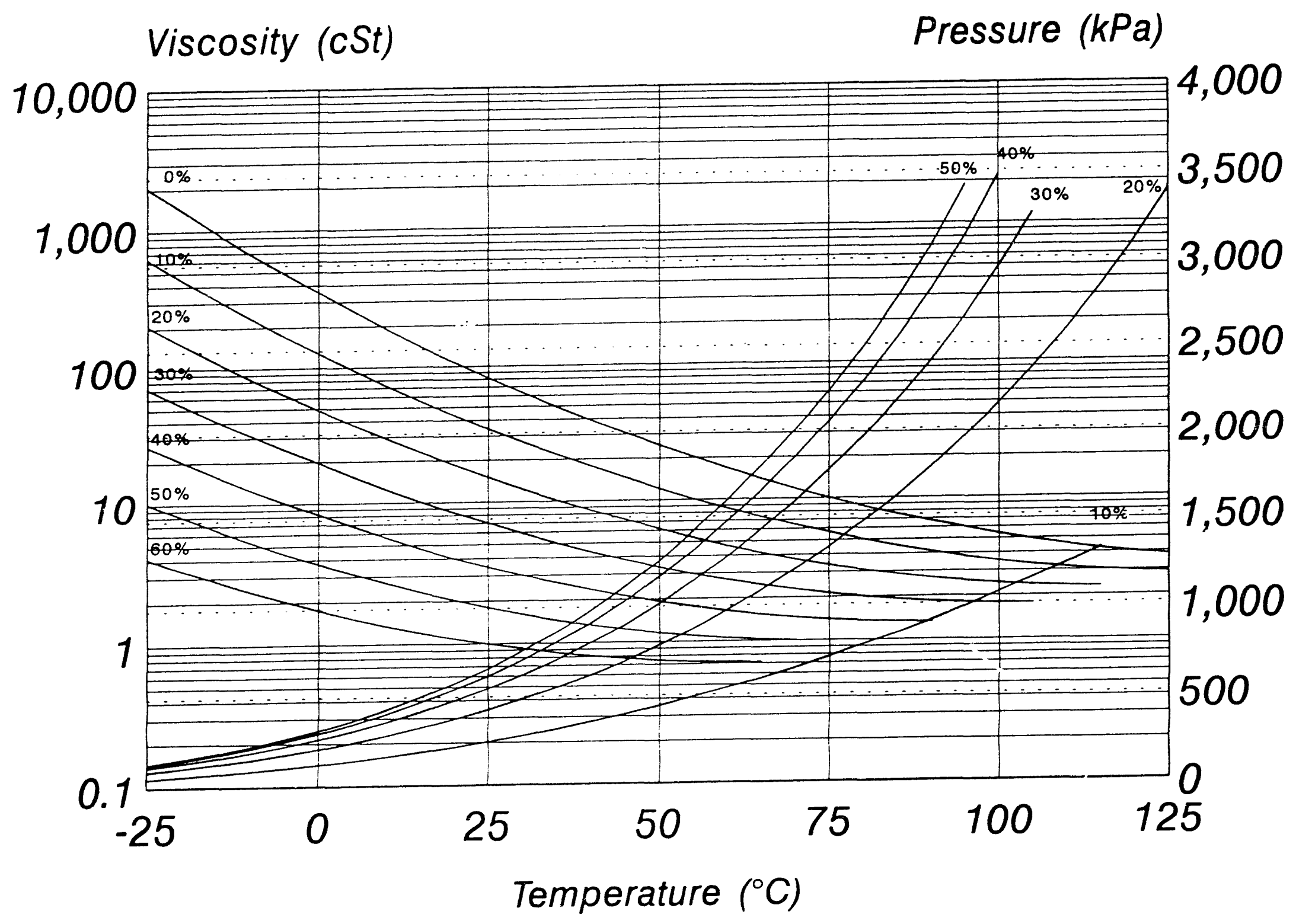


Density vs. Temperature

HFC-134a in 32 ISO VG Mixed Acid Polyolester

Figure 11

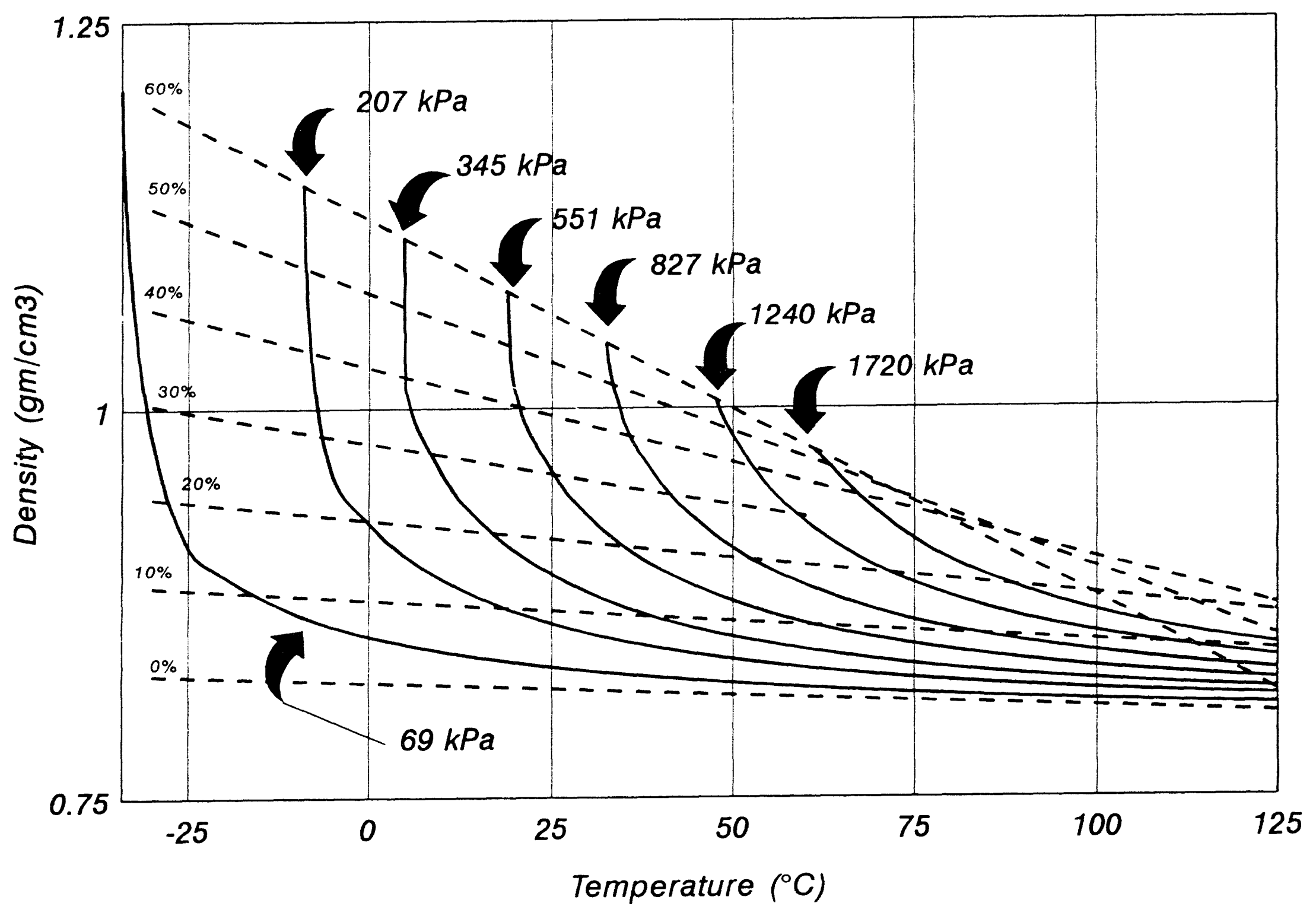




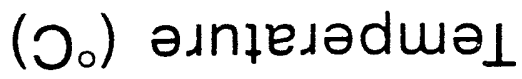

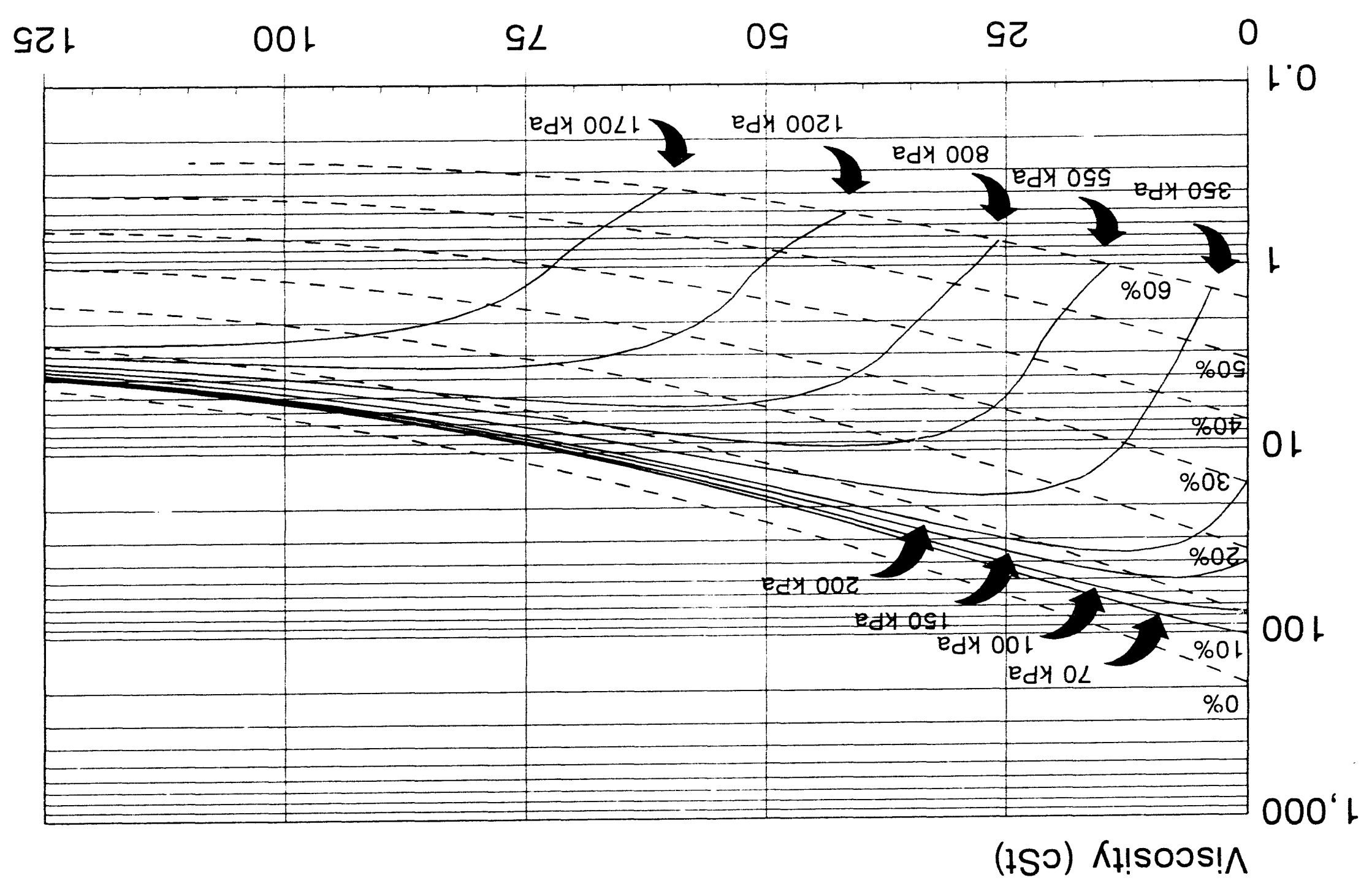

乙L ә

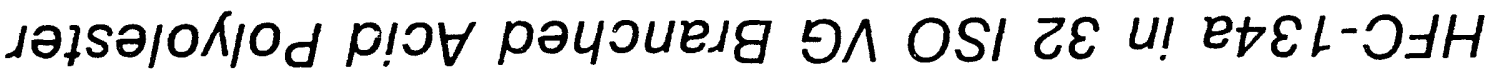

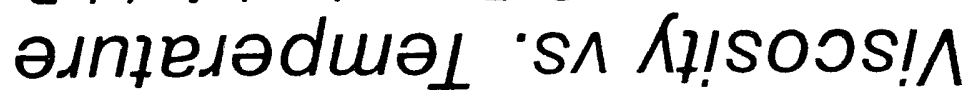




\section{Viscosity and Pressure at Constant Concentrations}

HFC-134a in 32 ISO VG Branched Acid Polyolester

Figure 13

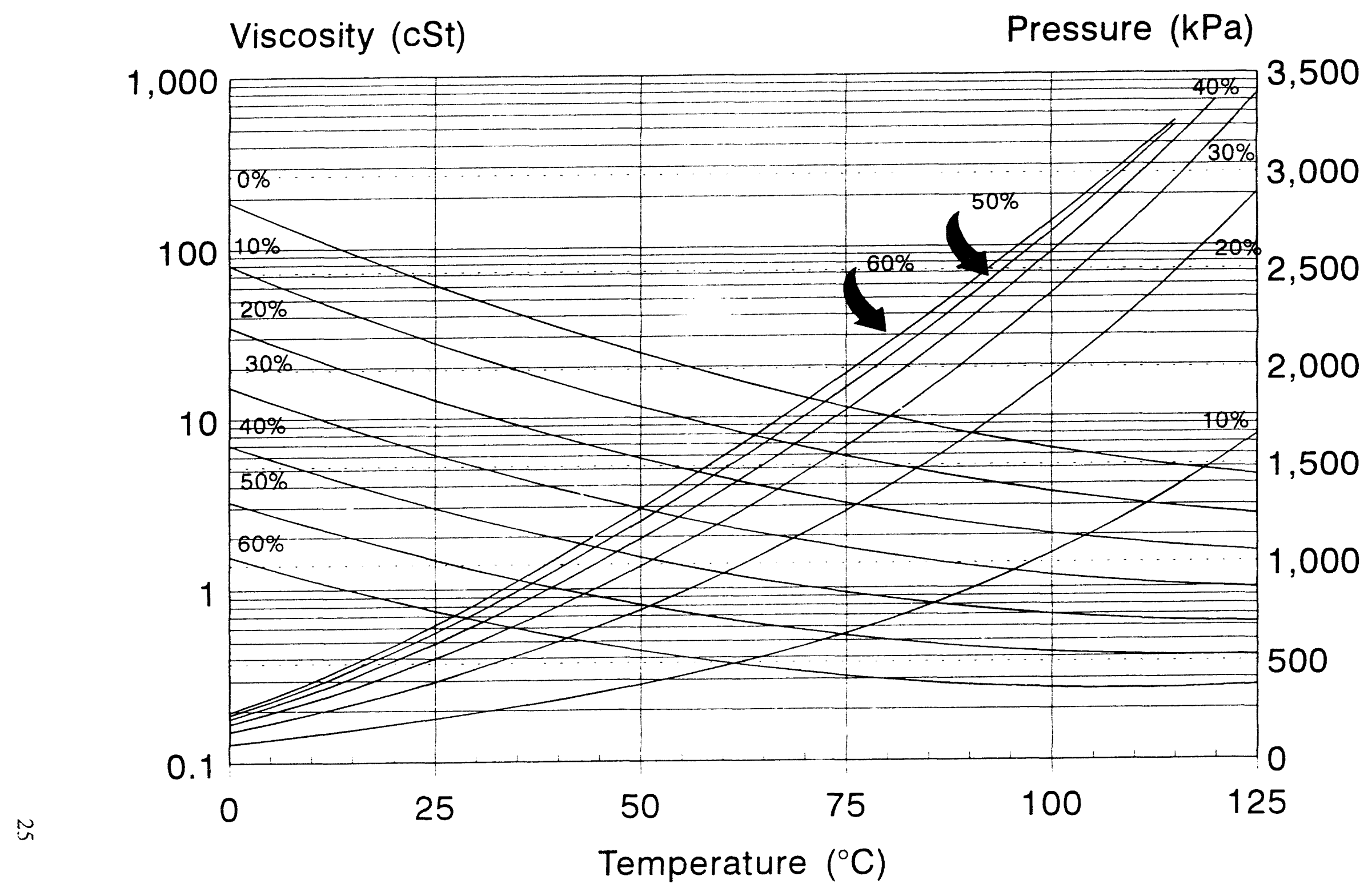


Density vs. Temperature

HFC-134a in 32 ISO VG Branched Acid Polyolester

Figure 14

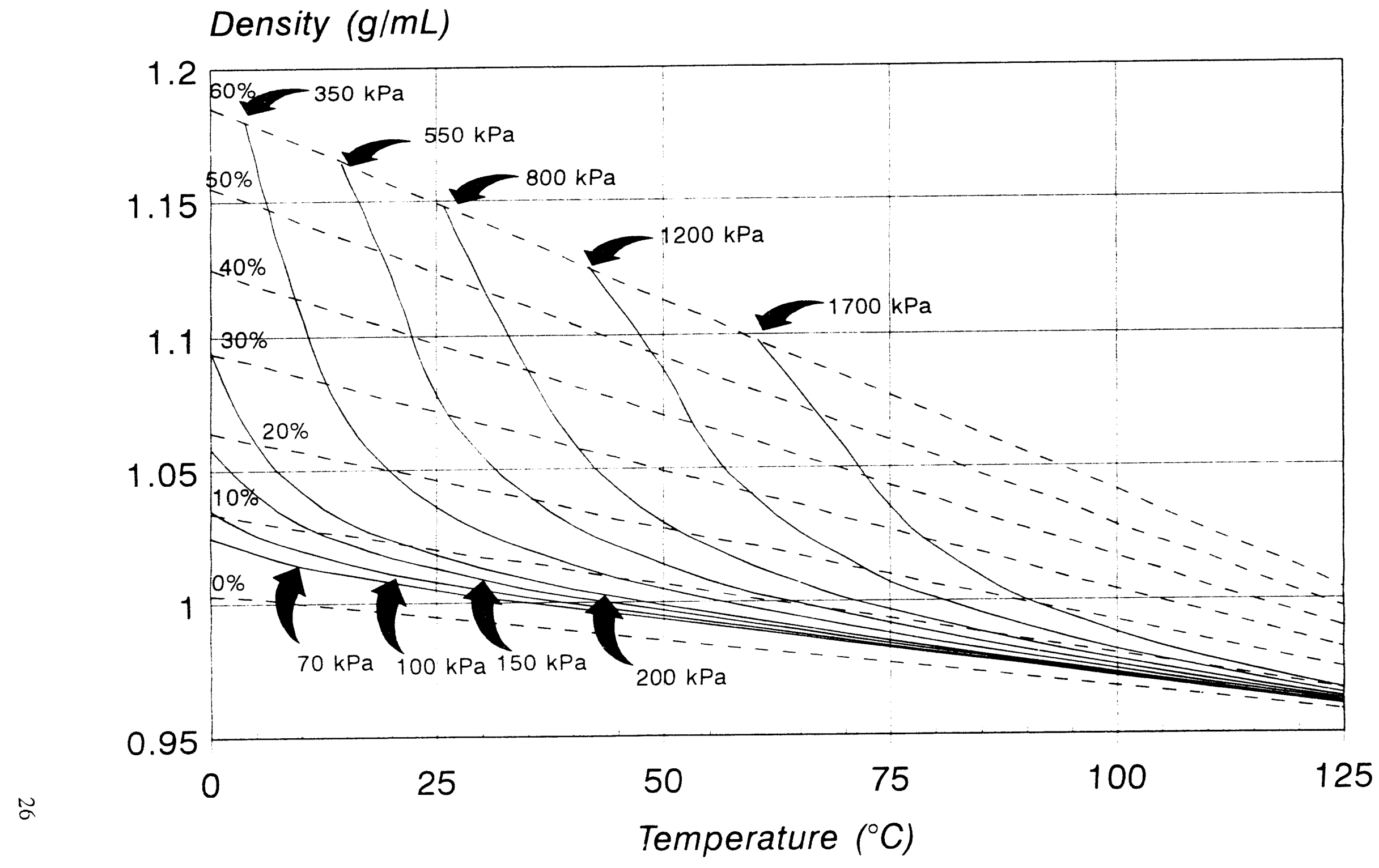




\section{Viscosity vs. Temperature HFC-143a in 32 ISO Branched Acid Polyolester}

Figure 15

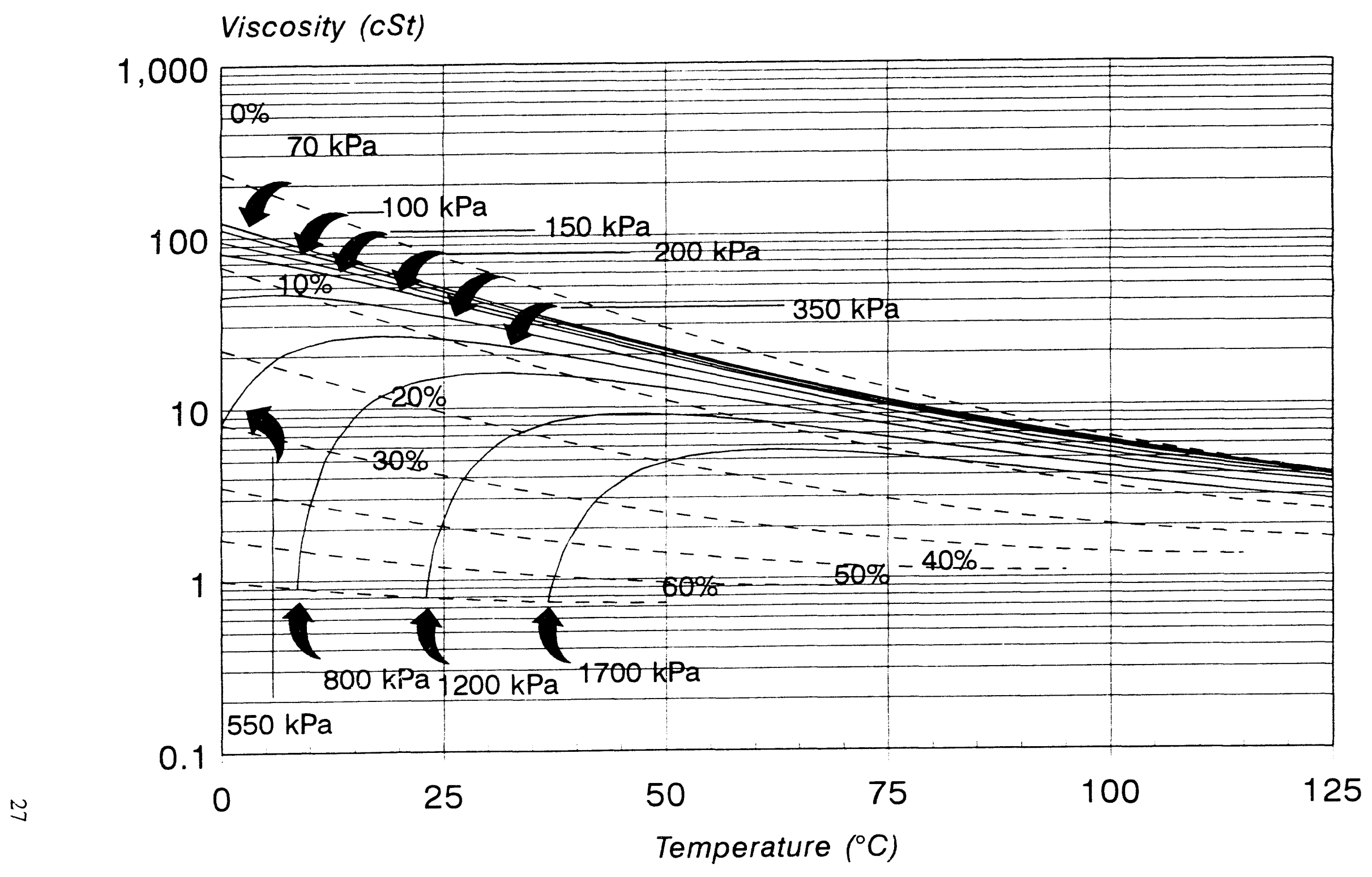




\section{Viscosity and Pressure at Constant Concentrations}

HFC-143a in 32 ISO VG Branched Acid Polyolester

Figure 16

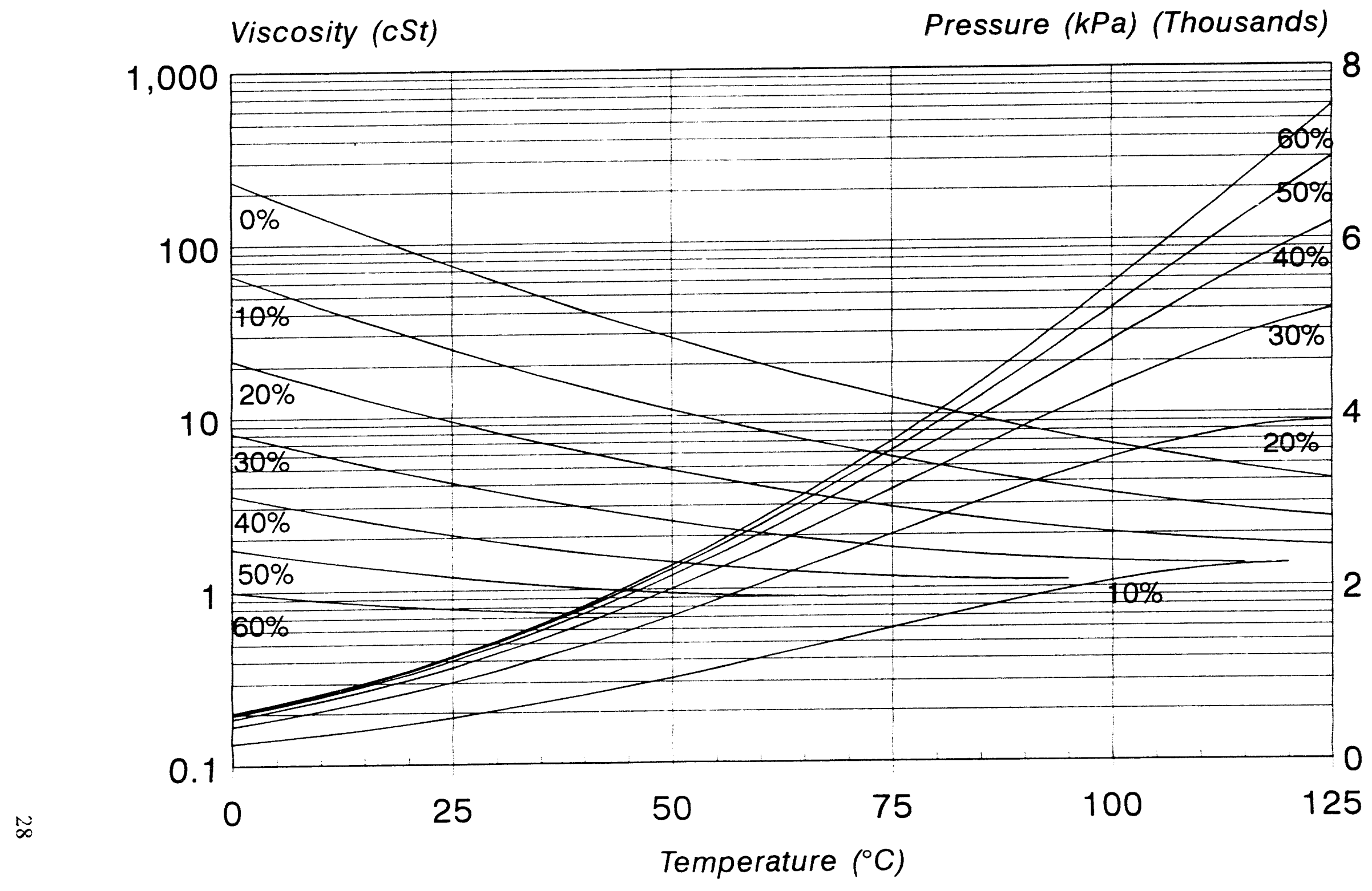




\section{Density vs. Temperature for Constant Concentrations HFC-143a with 32 ISO VG Branched Acid Polyolester}

\section{Figure 17}

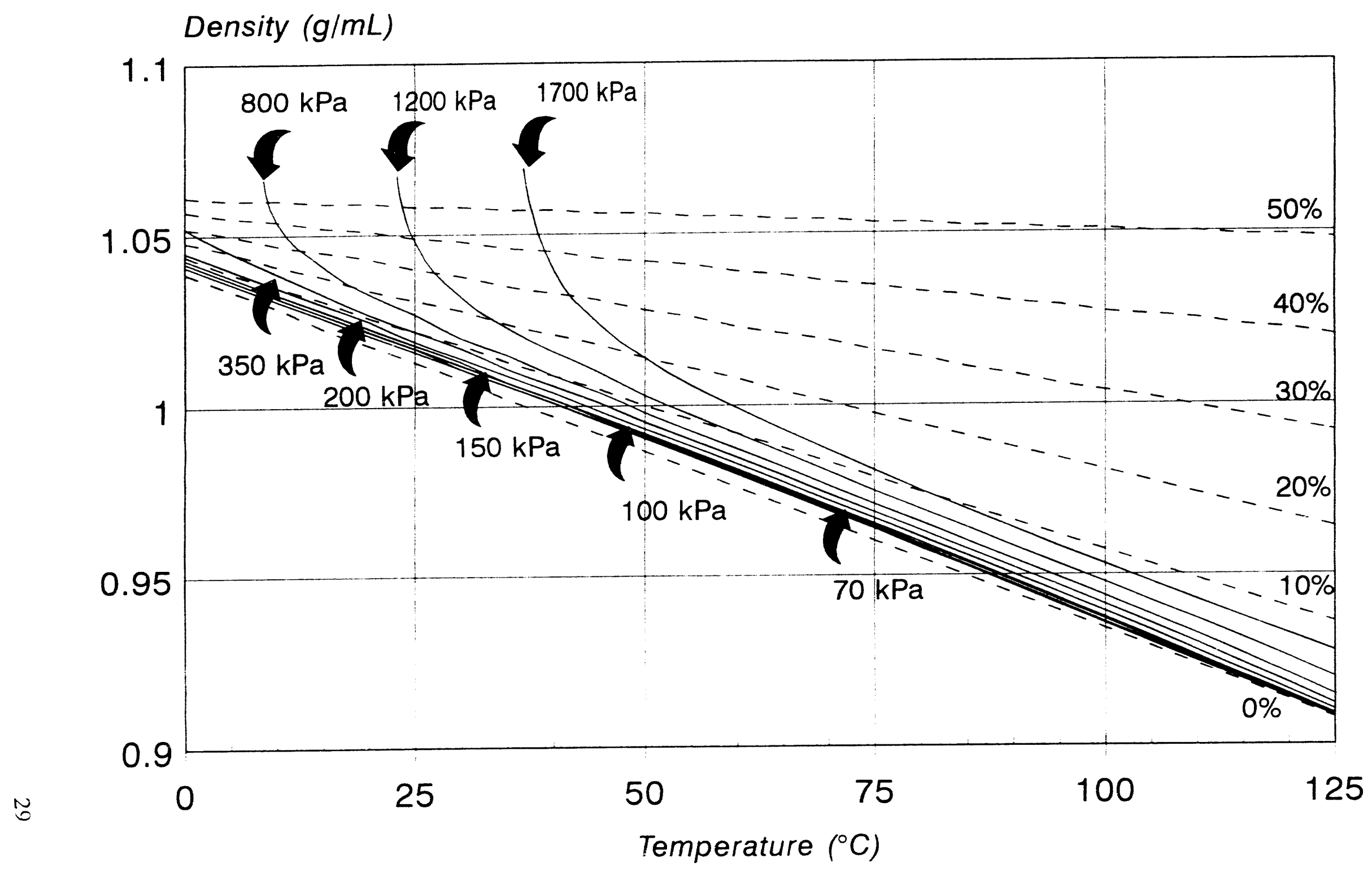




\section{Viscosity vs. Temperature}

HFC-143a in 32 ISO Mixed Acid Polyolester

Figure 18

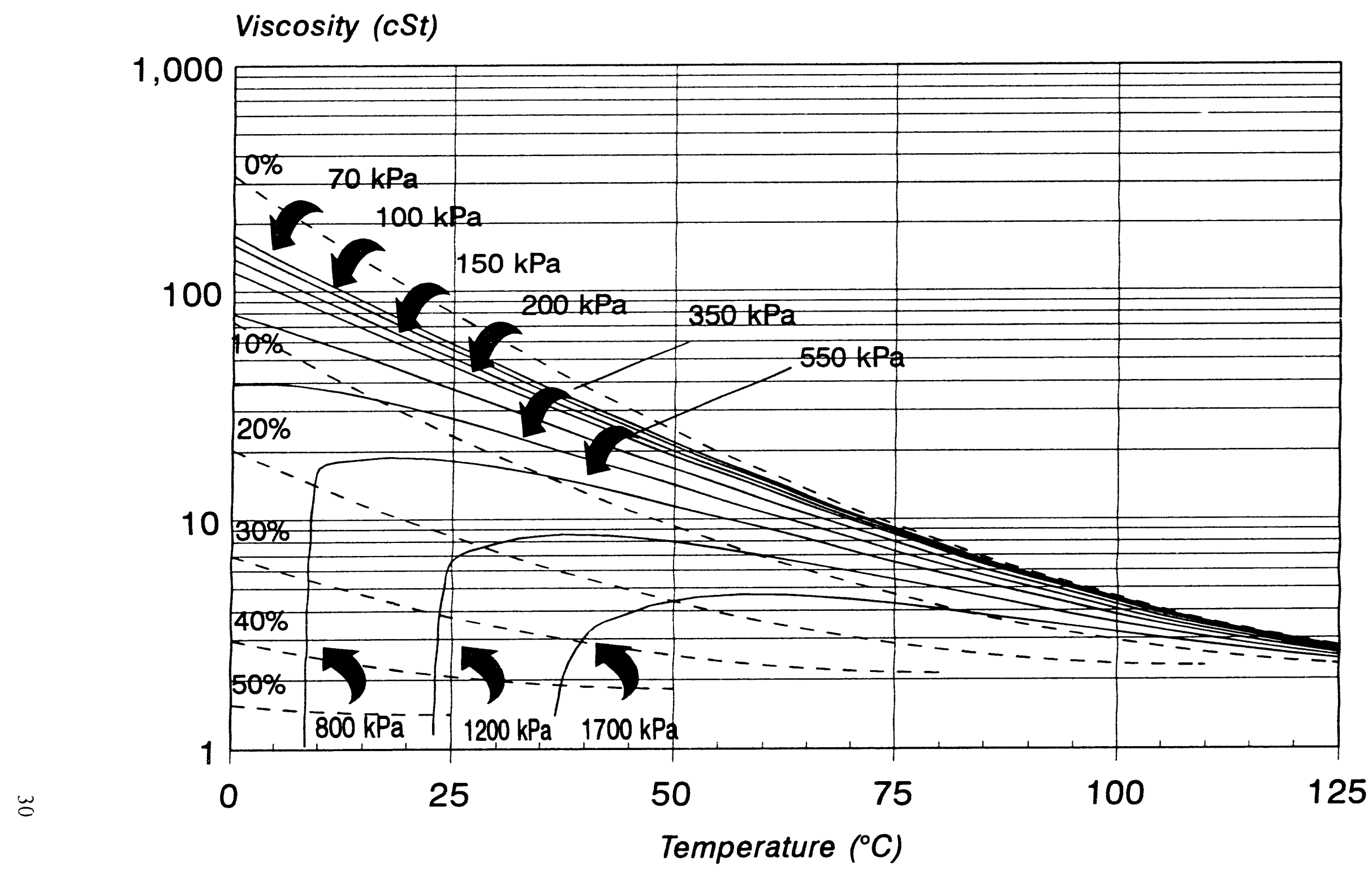




\section{Viscosity and Pressure at Constant Concentrations HFC-143a in 32 ISO VG Mixed Acid Polyolester}

Figure 19

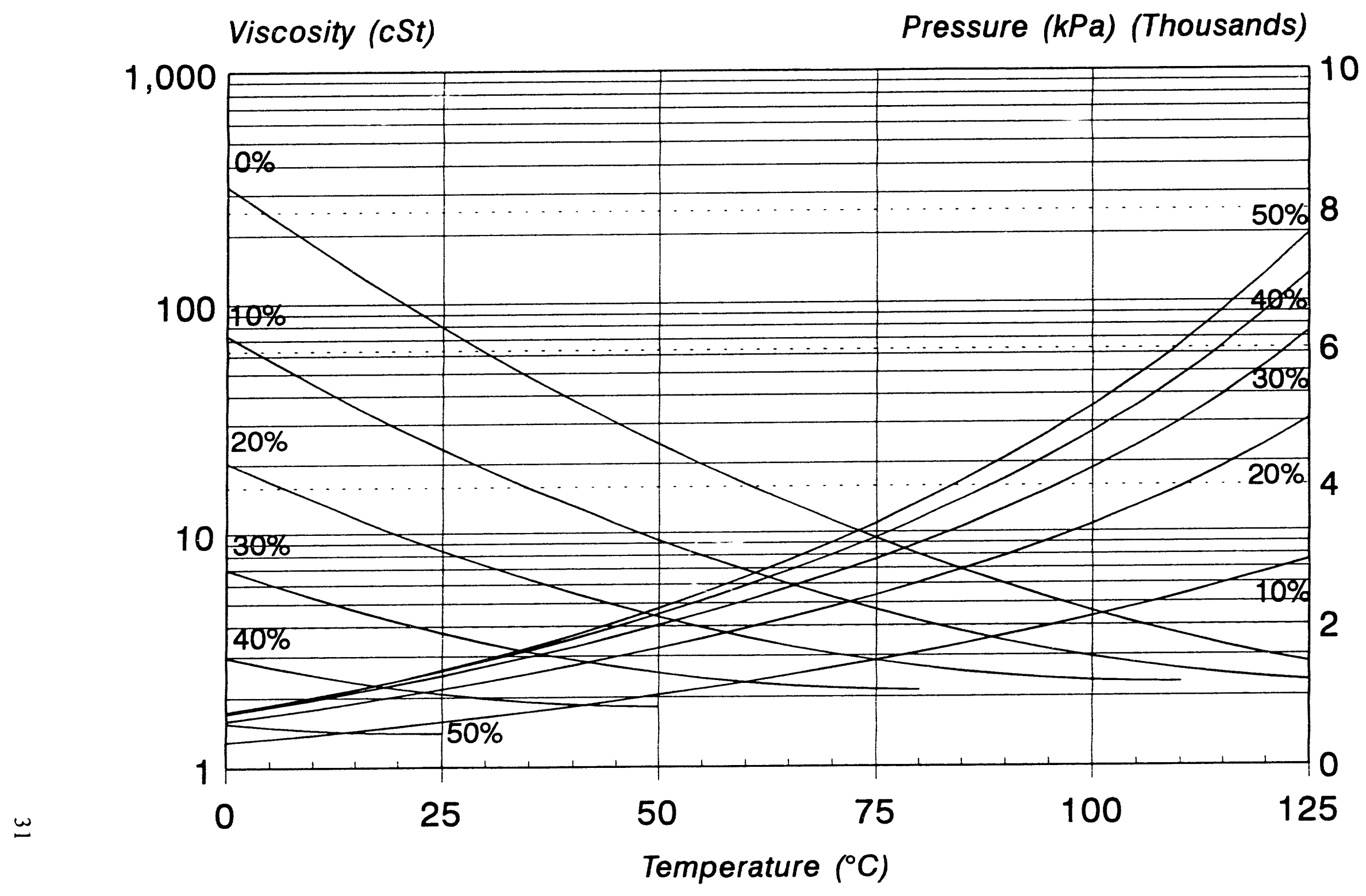


Density vs. Temperature

HFC-143a in 32 ISO VG Mixed Acid Polyolester

Figure 20

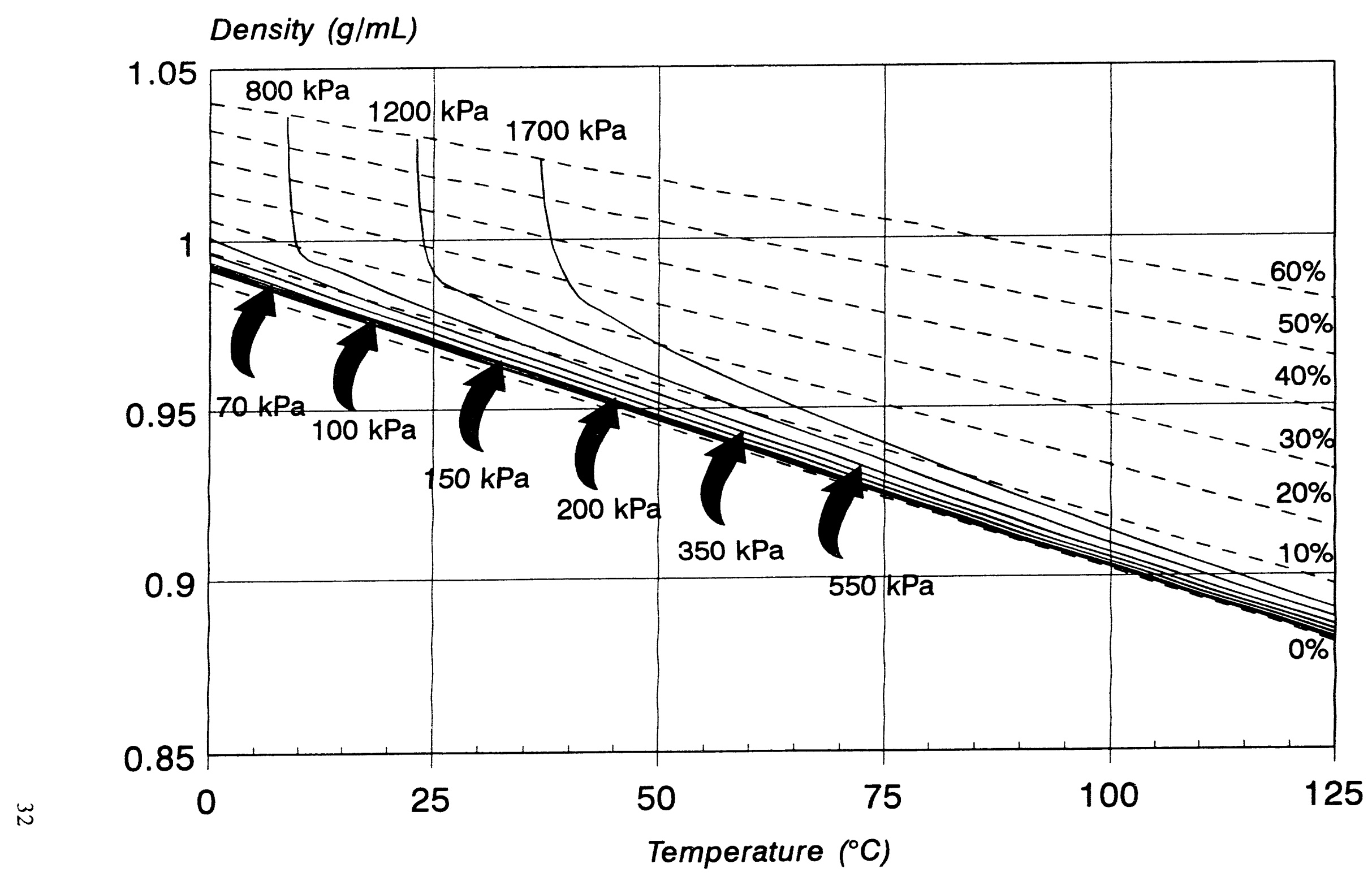




\section{Compliance with Agreement}

Imagination Resources, Inc. is in compliance with the contract agreement.

\section{Principal Investigator Effort}

The principal investigators have devoted 1750 hours toward the completion of this contract. Activities include reporting early refrigerant miscibility information to the Technical Oversight Group, and measuring viscosity, density, and solubility. 


\section{References}

Albright, L.F., Mendelbaum, A.S. Solubility and Viscosity Characteristics of Mixtures of Lubricating Oils and Freon-13 or-115 Refrigerating Engineering: 37-47; 1956.

Albright, L.F., Lawyer, J.D. Viscosity-Solubility, Characteristics of Mixtures of Refrigerant-13B1 and Lubricating Oils ASHRAE Journal; April 1967.

Cavestri, R.C. Measurements of the Solubility, Viscosity and Density of Synthetic Lubricants/HFC-134a Mixtures (Final Report: ASHRAE RP-716): April 1993.

Little, J.L. Viscosity of Lubricating Oil-Freon-22 Mixtures Refrigerating Engineering; November 1991.

Nissen, D.A. A Single Apparatus for the Precise Measurement of the Physical Properties of Liquids at Elevated Temperature and Pressure Sandia National Laboratories: Livermore SAN 80-803. October 1981.

Nissen, D.A., Macmillan, D.C. Apparatus for the Precise Measurement of the Physical Properties of Liquids at Elevated Temperature and Pressure Rev. Sci. Instrum.; 54(7): 861.

Parmelee, H.M. Viscosity of Refrigerant-Oil Mixtures at Evaporator Conditions ASHRAE Transactions; 70:173.

Spauschus, H.O., Speaker, L.M. A Review of Viscosity Data for Oil Refrigerant Solutions ASHRAE Transactions; 2(93): 1987.

Spauchus, H.O., Henderson, D.R. Ed. D.R. Tree. New Methods for Determining Viscosity and Pressure of Refrigerant/Lubricant Mixtures Proceedings of the 1990 USMC/IIR-Purdue Refrigeration Conference.

Van Gaalen, N.A., Pate, M.B., Zoz, S.C. The Solubility and Viscosity of HCFC-22 in Naphthenic Oil and Alkylbenzene at High Pressures and Temperatures ASHRAE Transactions; 1(97): 1991. 


\section{APPENDICES}

Appendix A: Miscibilities of Refrigerant Blends A-F

Appendix B: Viscosity and Gas Solubility of 32 ISO VG Mineral Oil at Various

Temperatures with HCFC-22.

Appendix C: Viscosity, Solubility, and Gas Fractionation of 32 ISO VG Mineral

Oil at Various Temperatures with R-502

Appendix D: Viscosity, Density, and Gas Solubility of 32 ISO VG Mixed Acid

Polyolester at Various Temperatures with HFC-134a.

Appendix E: Viscosity, Density, and Gas Solubility of 32 ISO VG Branched Acid

Polyolester at Various Temperatures with HFC-134a.

Appendix F: Viscosity, Density, and Gas Solubility of 32 ISO VG Branched Acid

Polyolester at Various Temperatures with HFC-14?a

Appendix G: Viscosity, Density, and Gas Solubility of 32 ISO VG Mixed Acid

Polyolester at Various Temperatures with HFC-143a. 


\section{APPENDIX A}

\section{Miscibilities of Refrigerant Blends A-F}

The following graphs present data about the miscibility of four different polyolesters and one alkylbenzene with six refrigerant blends at three different refrigerant/lubricant concentrations. This information was used to select the lubricants tested in this study. 


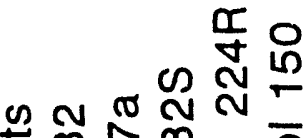

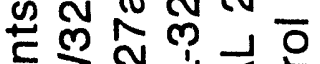

ธั่

.

\begin{tabular}{llllll}
\hline \multirow{3}{3}{} & $\|$ & $\|$ & $\|$ & $\|$ & $\|$ \\
\hline
\end{tabular}

$\tau$

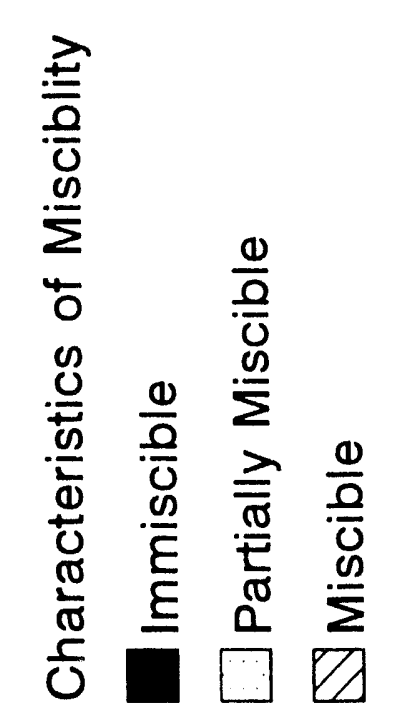

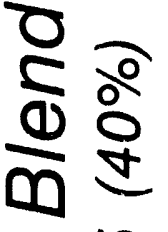

$\approx \stackrel{n}{2}$

$\sqrt{0}$

(1)

(1) 난

OI ব்

$\neq 20$

(1)

두요

4 o

08

$\geqslant N$

ले

$\underline{0}$

U

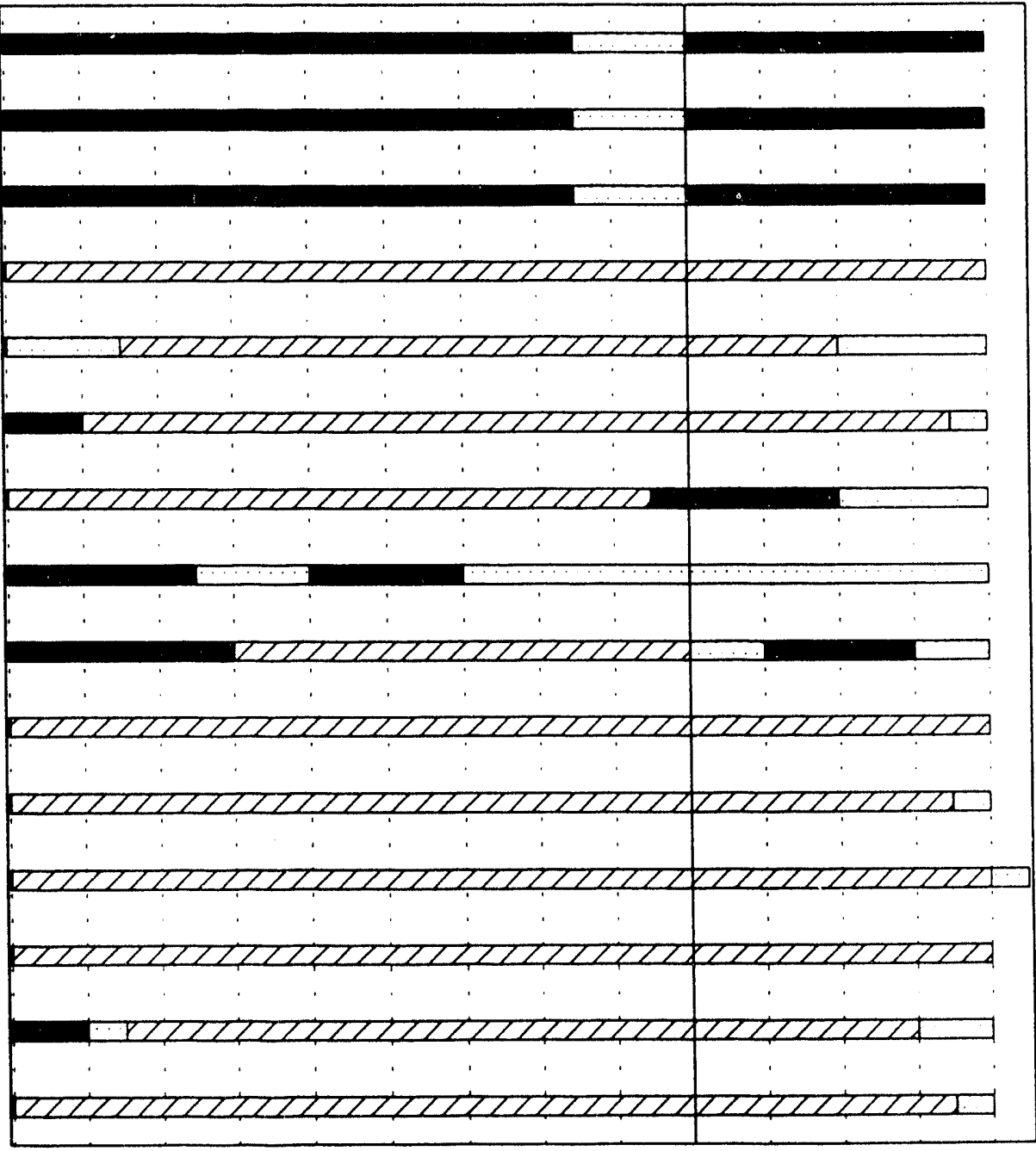

$\% 09-\exists$

$\%$ \%己 $-\exists$

$\% \subseteq-\exists$

$\% 09-\mathrm{a}$

$\%$ ९ट -

$\%$ G - $\quad \frac{0}{8}$

$\% 09-0$ ह

\% Sट -

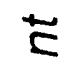

$\% s-0$

$\% 09-9$

.0

事

$\Sigma$

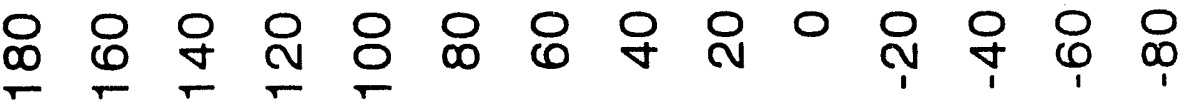

(to) әлпџеләдшә1 

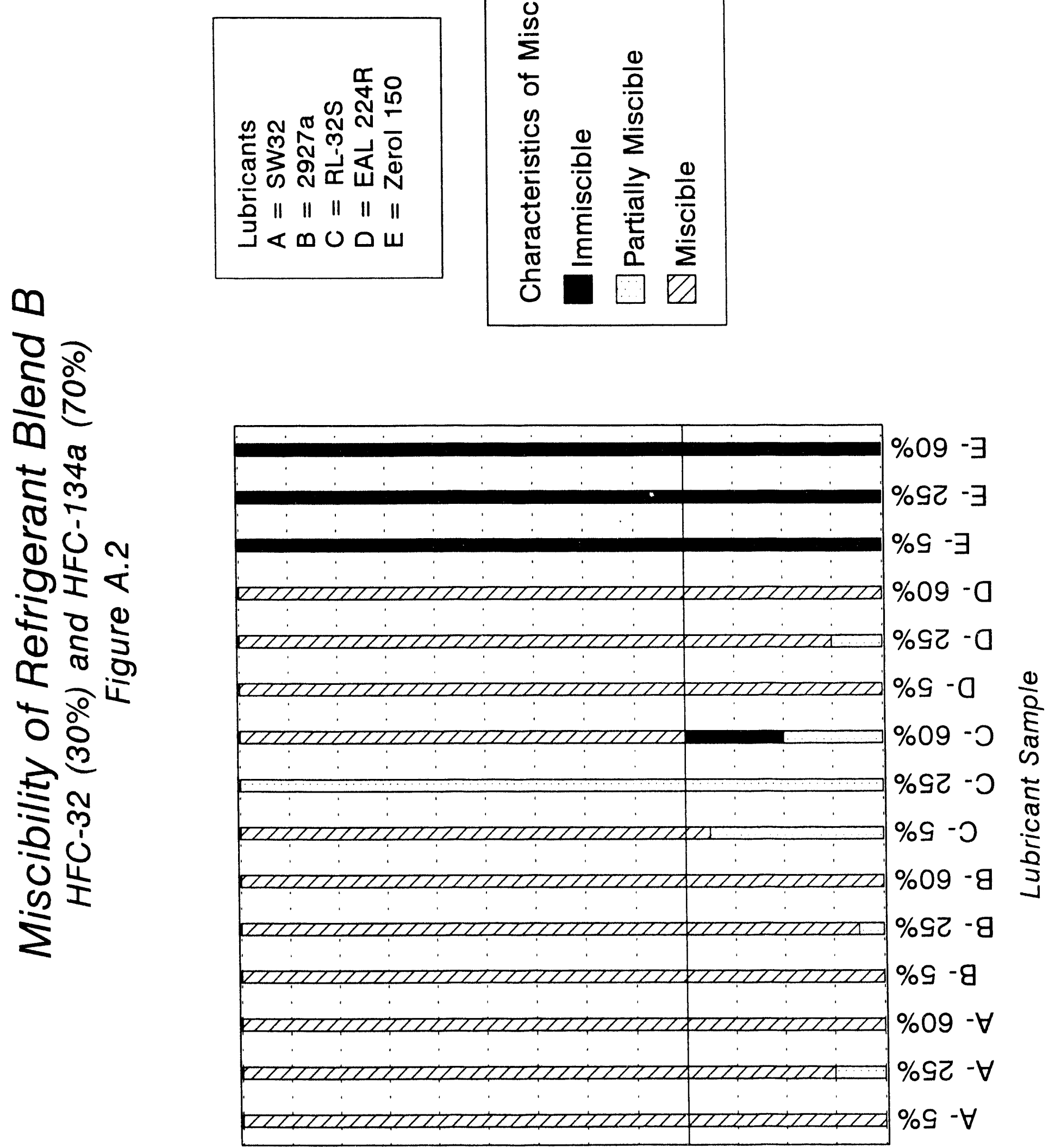


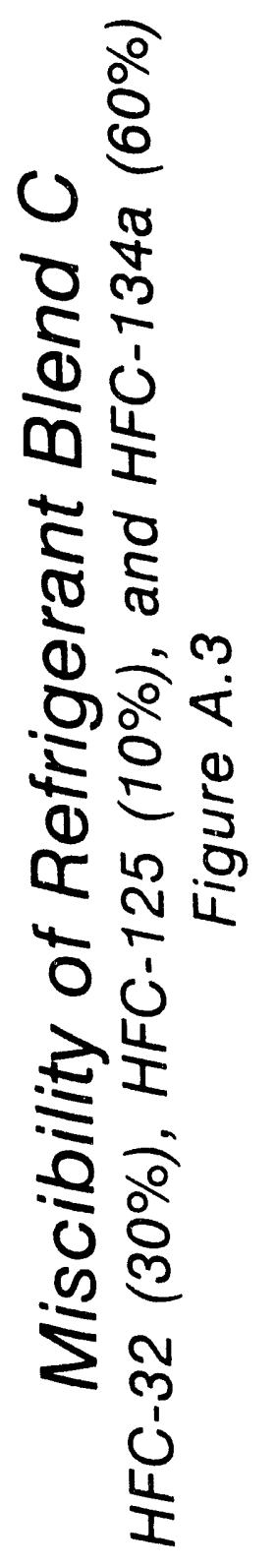

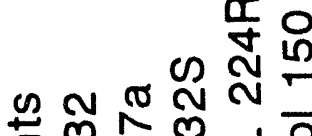

ट N N

త্

을 || || ||

س

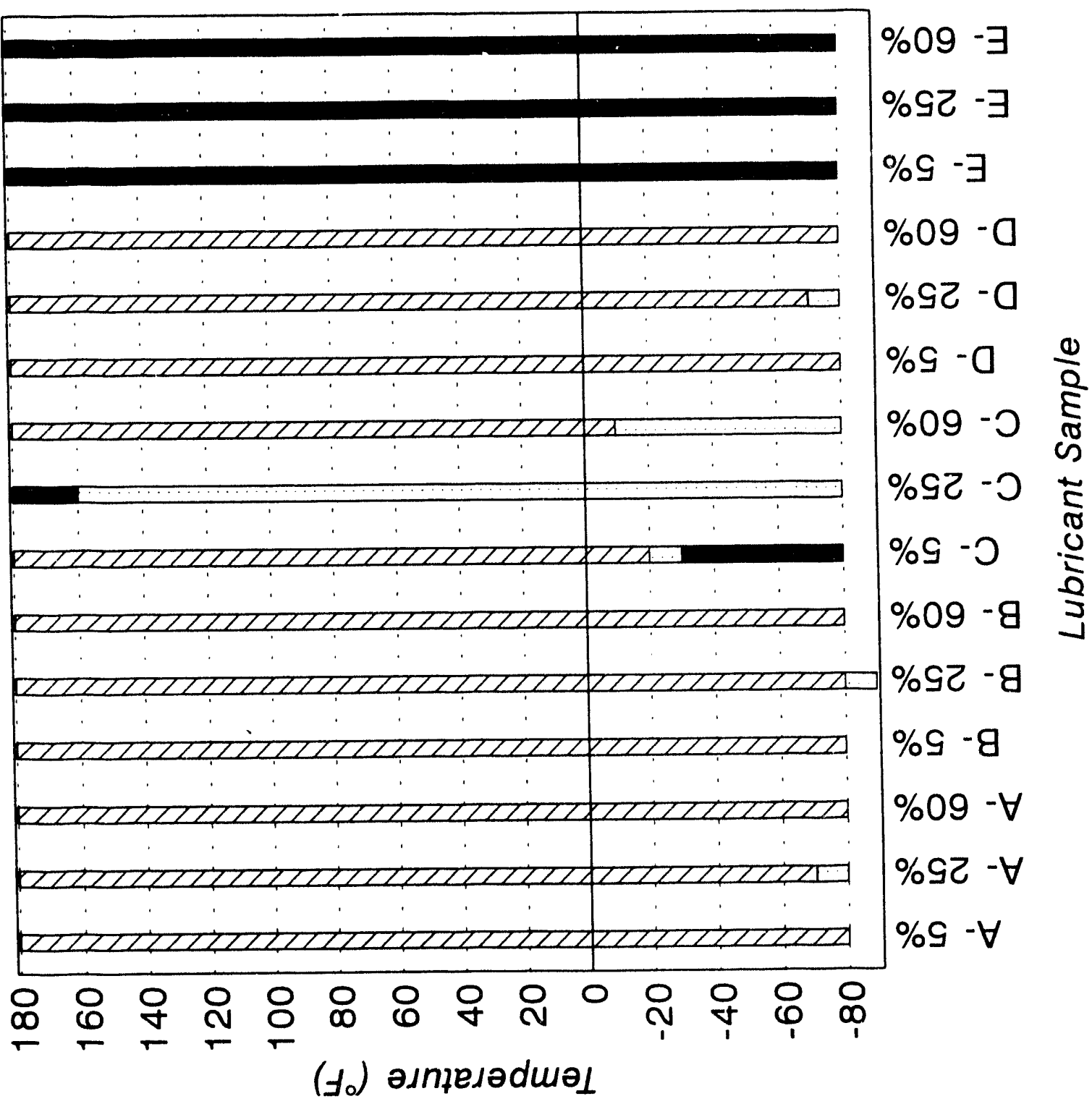




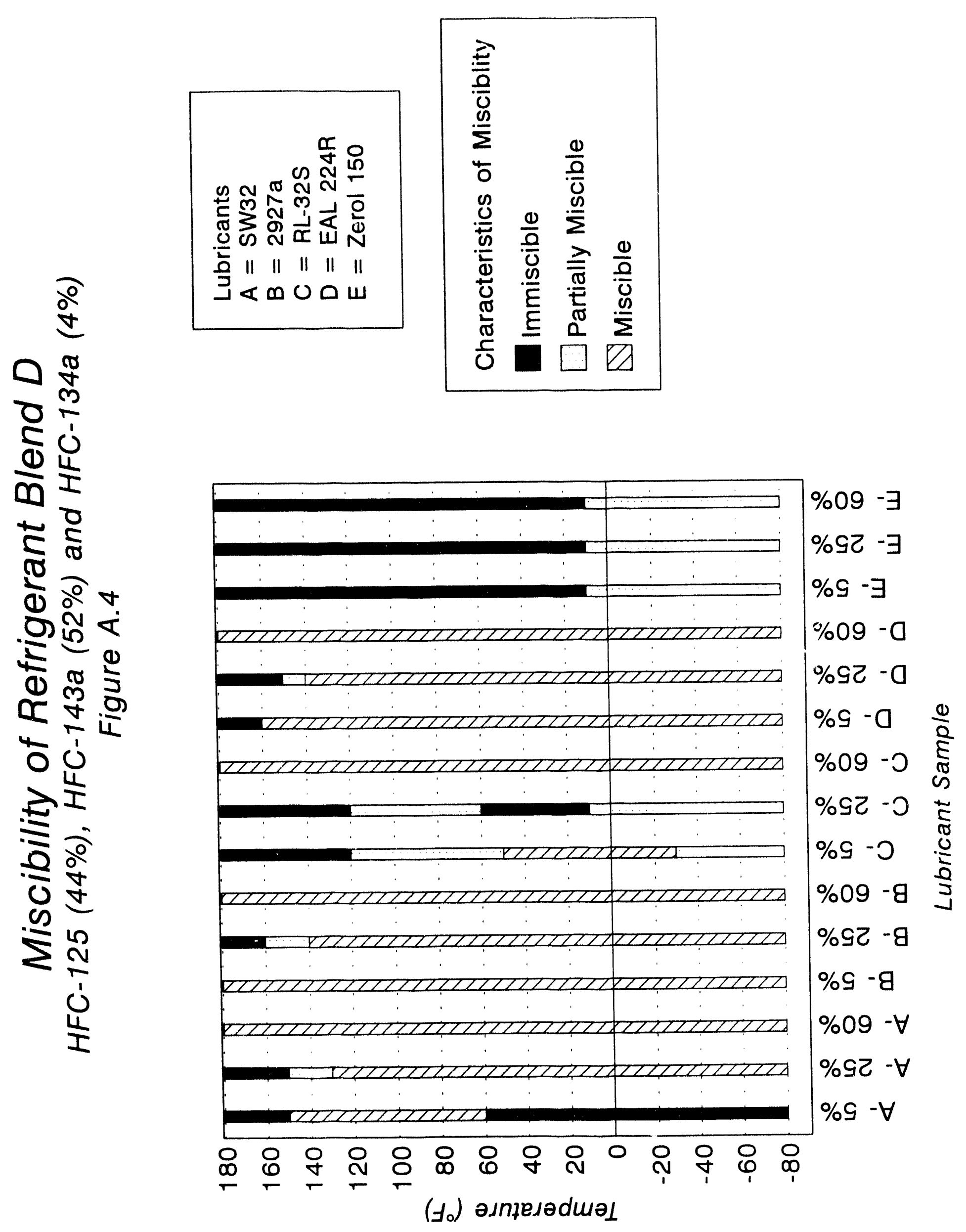


วิ

10

웅

9

స

บ

แ

రิ

$\frac{\Phi}{\infty}$

ลे

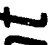

\&

(ช)

(1)

(1) $\pi$

D $0<$

\&I $\frac{4}{5}$

(1)

व 2 의

410

010

$\geqslant 1$

$=N$

$\overline{0} 7$

$-0$

$0 \frac{4}{1}$

$\sum$

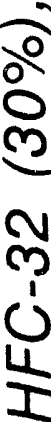

n $⿻$ ก

- $N \stackrel{1}{N}$

๙

ن ल ๙

气ํㄴ || || || ||

马 $\varangle$ \
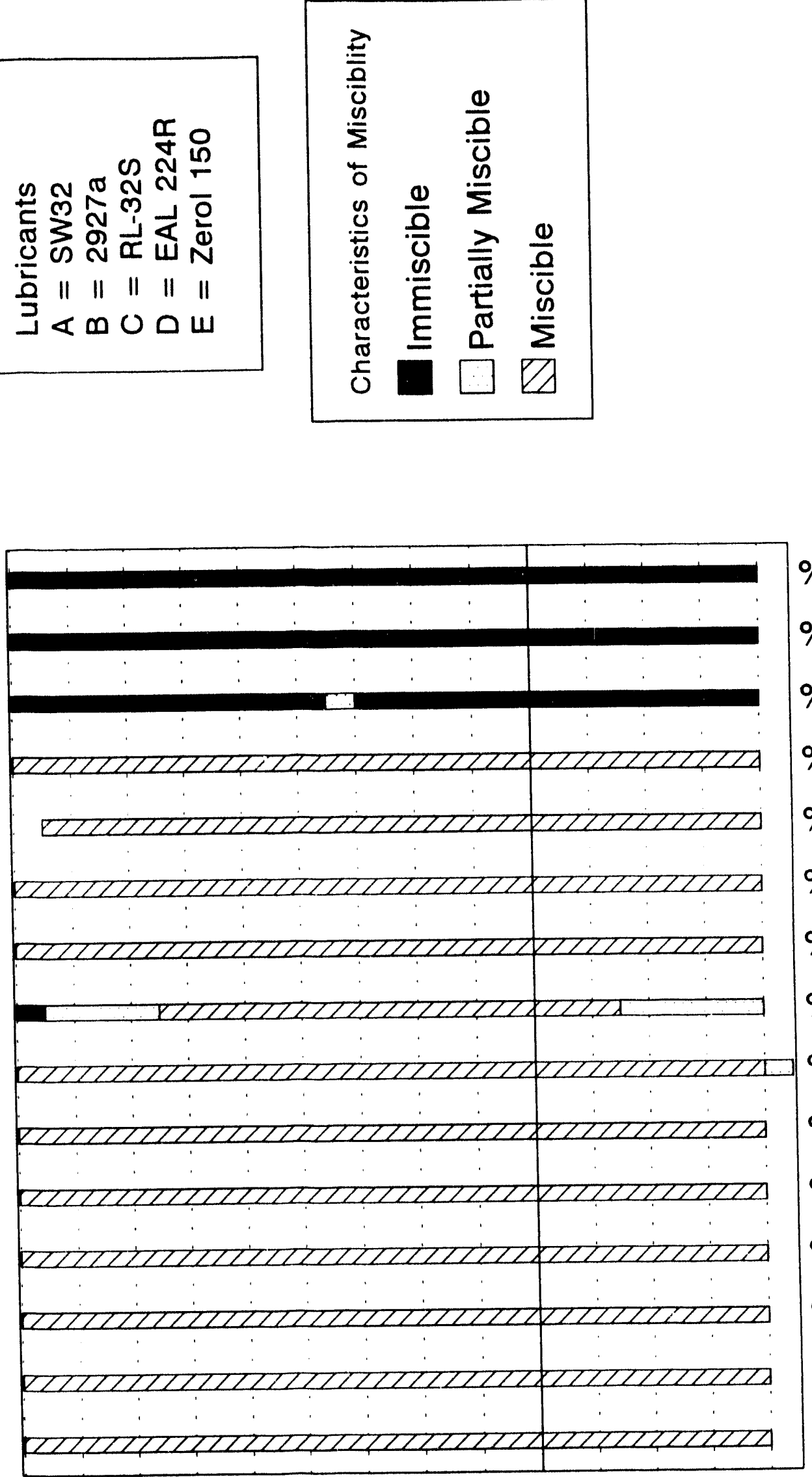

$\% 09-\exists$

$\% 92-\exists$

$\% \subseteq-\exists$

$\% 09-0$

$\%$ ९ट -0

$\% S-\mathrm{C}$

$\% 09-0 \frac{\frac{0}{0}}{\frac{\pi}{2}}$

$\%$ Sट -0

$\% 9-0$

$\% 09-8$

$\%$ G -8

$\% 9-8$

$\% 09-\forall$

$\%$ \% $-\forall$

$\% S-\forall$

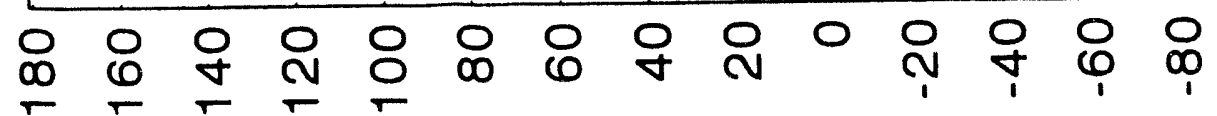

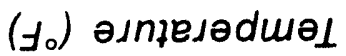


Temperature $\left({ }^{\circ} \mathrm{F}\right)$

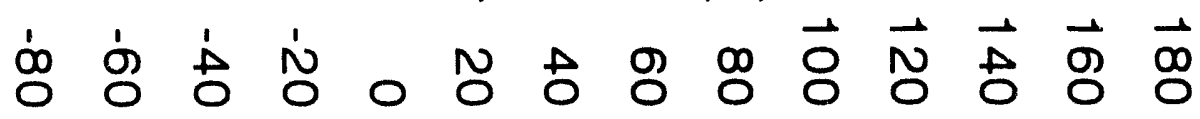
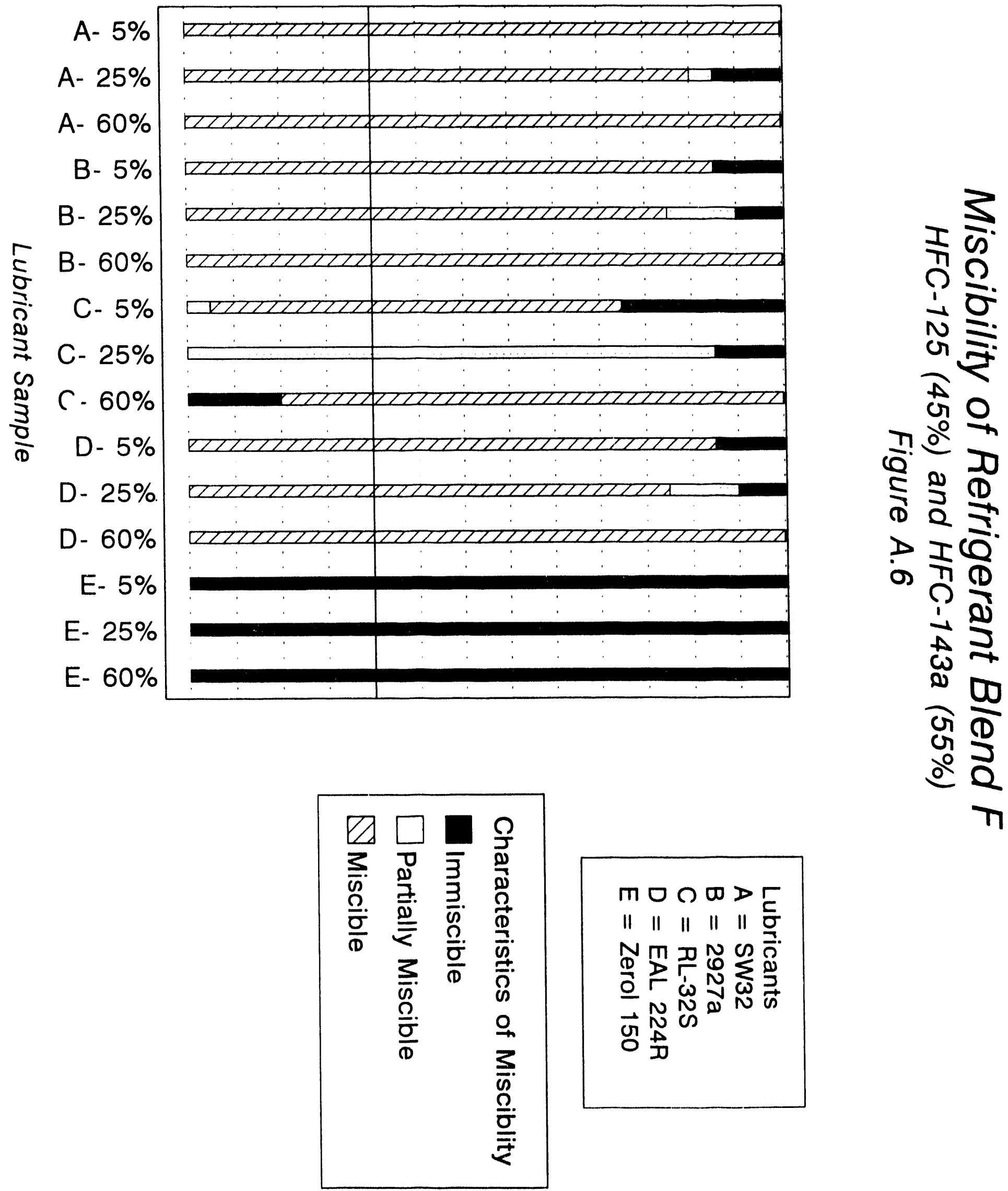


\section{APPENDIX B:}

Viscosity and Gas Solubility of 32 ISO VG Mineral Oil at Various Temperatures with HCFC-22 


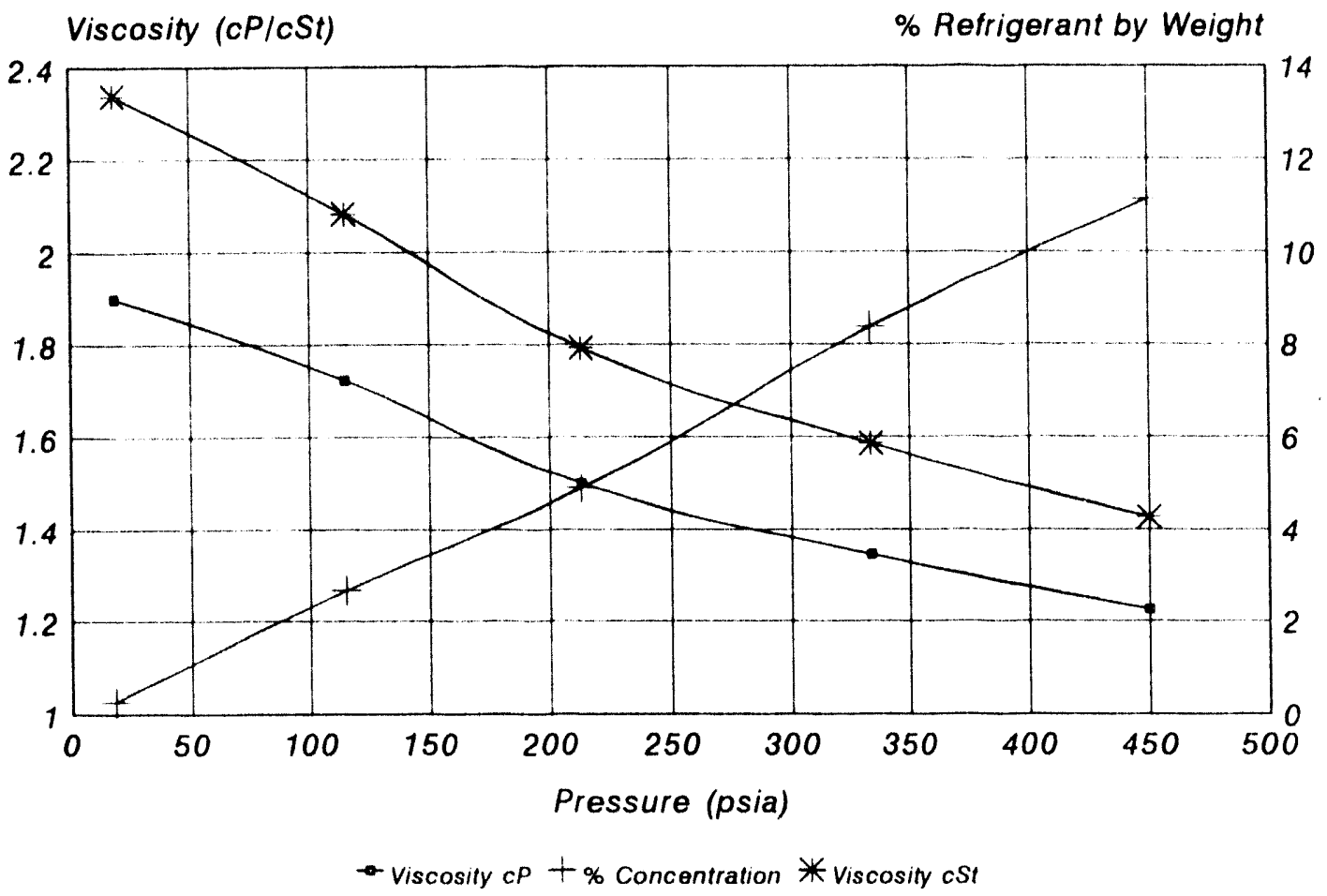

Viscosity via Gas Solubility Equilibrium

Oil degassed to 20 Millitorr

Viscosity and Gas Solubility 32 ISO VG Mineral Oil with HCFC-22 at $100^{\circ} \mathrm{C}$

Figure $B .2$

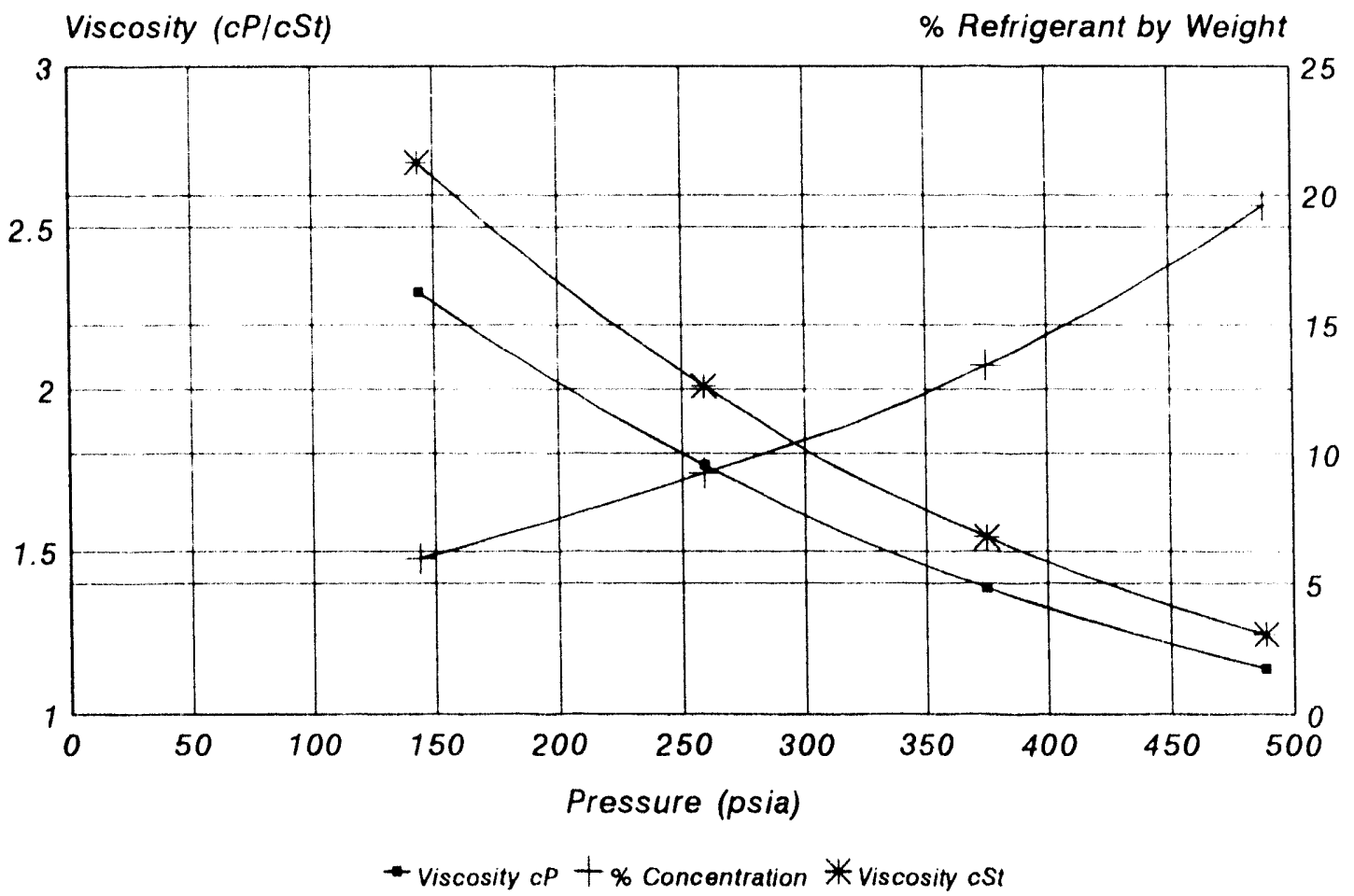


Viscosity and Gas Solubility

32 ISO VG Mineral Oil with HCFC-22 at $80^{\circ} \mathrm{C}$

Figure $B .3$

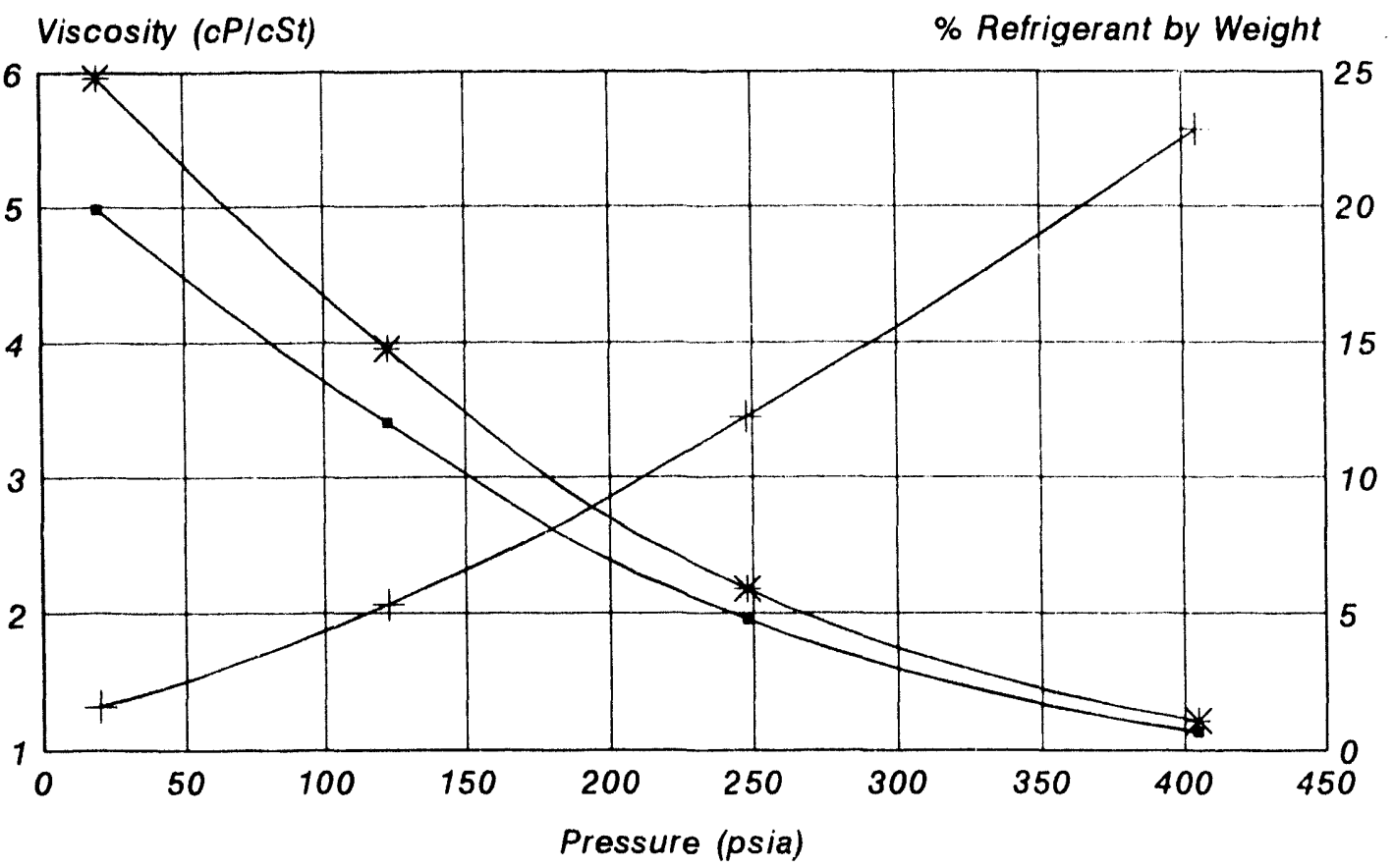

- Viscosity cP $+\%$ Concentration $*$ Viscosity cSt

Viscosity via Gas Solubility Equilibrium Oil degassed to 20 Millitorr

Viscosity and Gas Solubility 32 ISO VG Mineral Oil with HCFC-22 at $60^{\circ} \mathrm{C}$

Figure $\mathrm{B.4}$

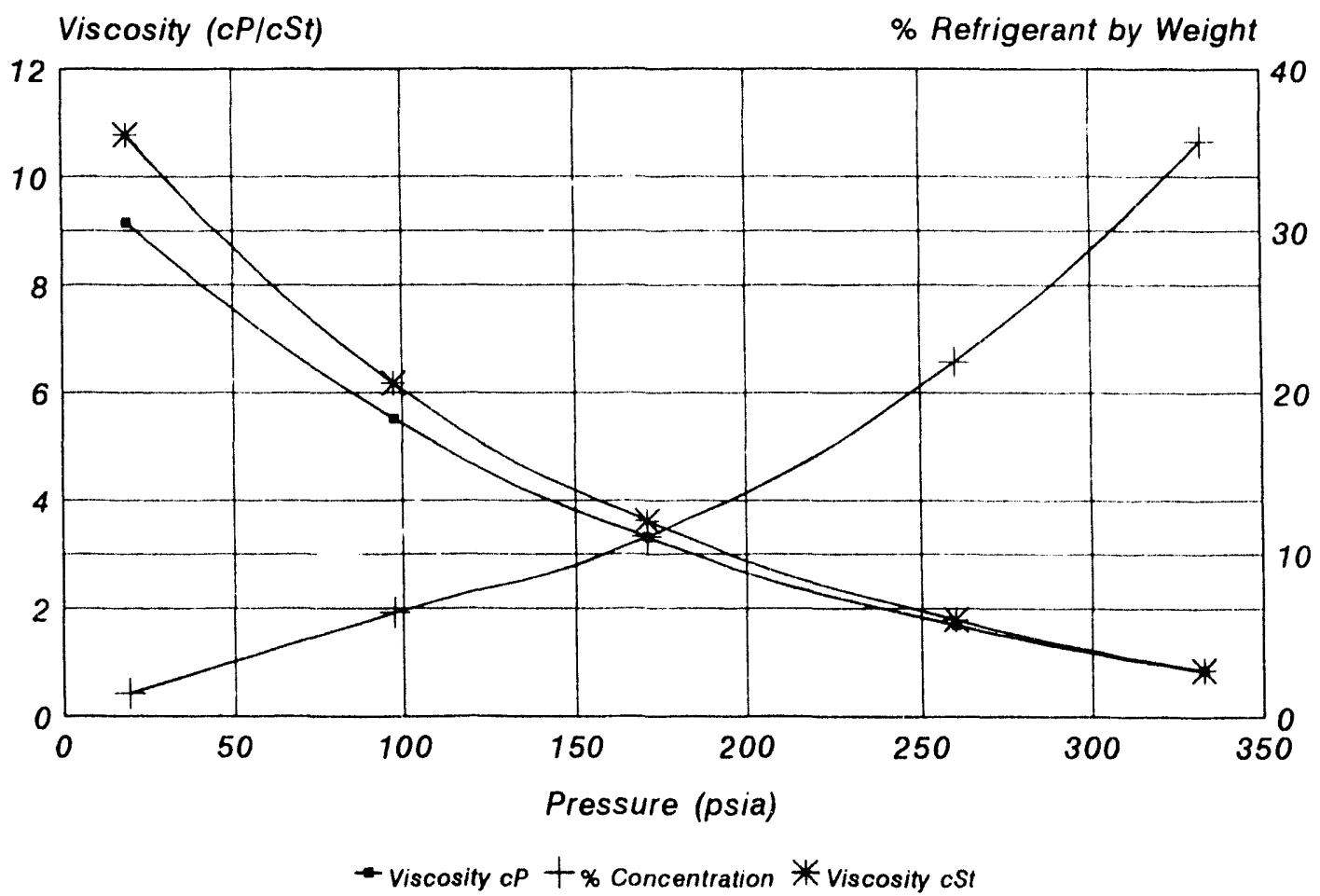




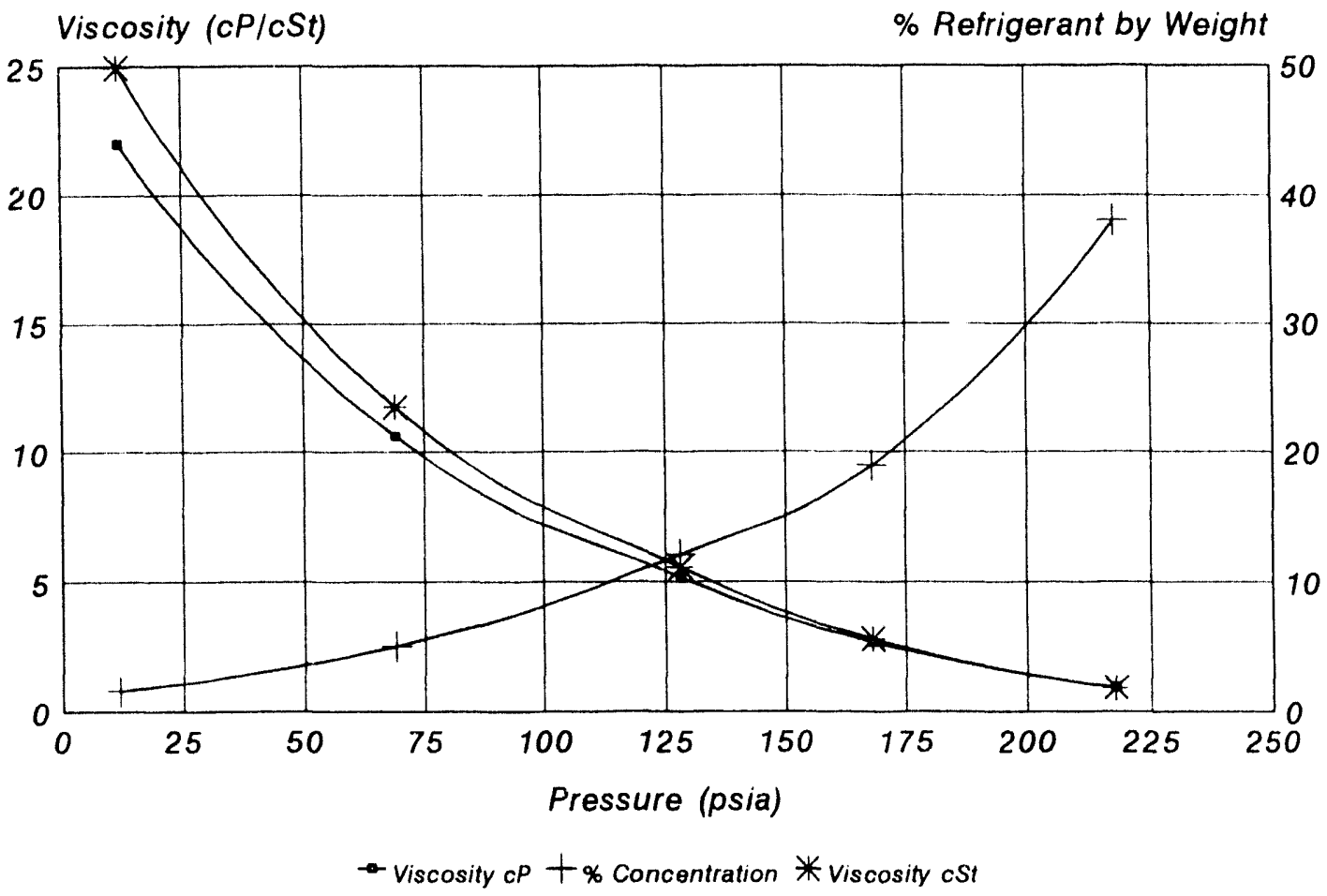

Viscosity via Gas Solubility Equilibrium

Oil degassed to 20 Millitorr

\section{Viscosity and Gas Solubility}

32 ISO VG Mineral Oil with HCFC-22 at $20^{\circ} \mathrm{C}$

Figure B.6

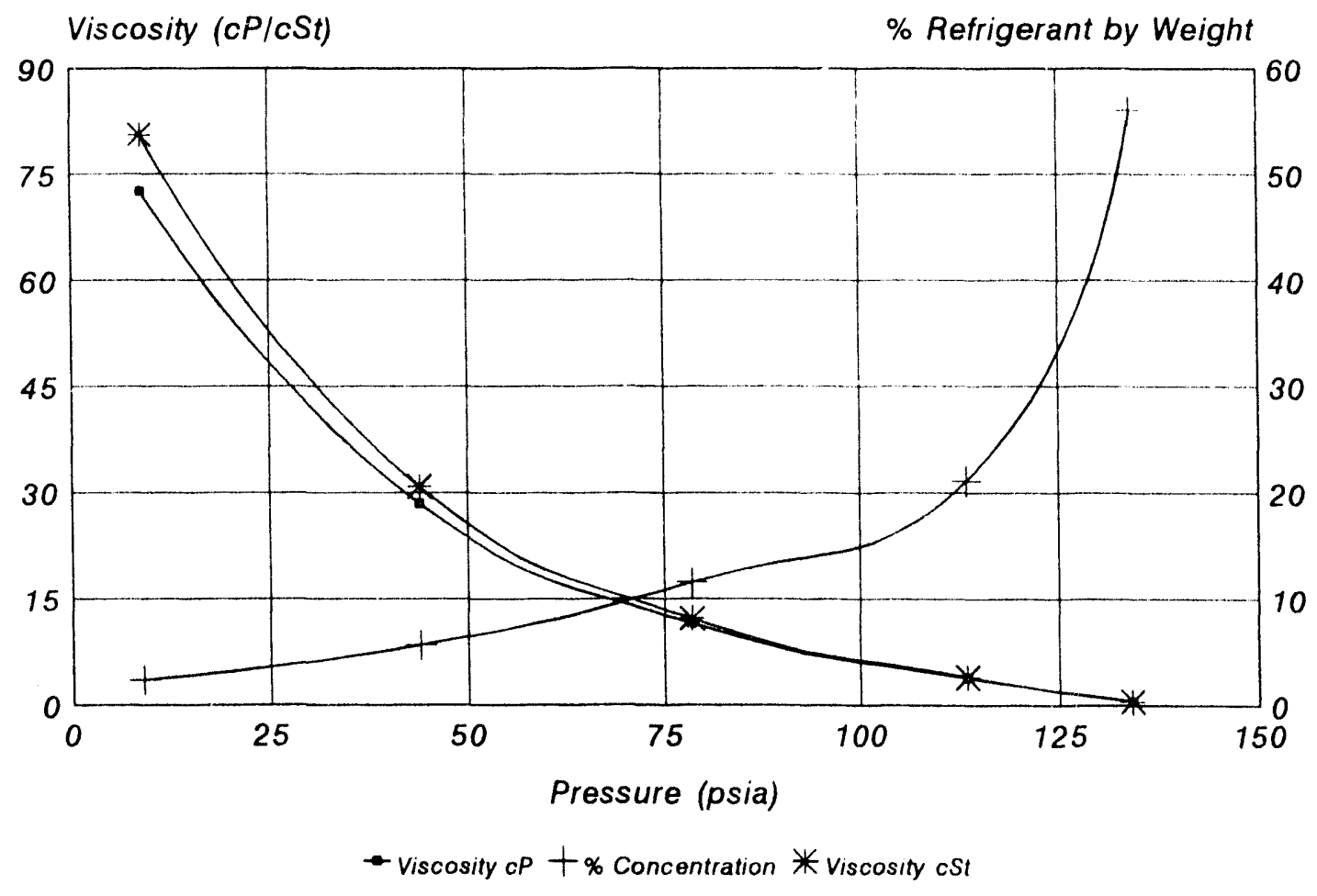




\section{Viscosity and Gas Solubility}

32 ISO VG Mineral Oil with HCFC-22 at $0^{\circ} \mathrm{C}$

Figure B.7

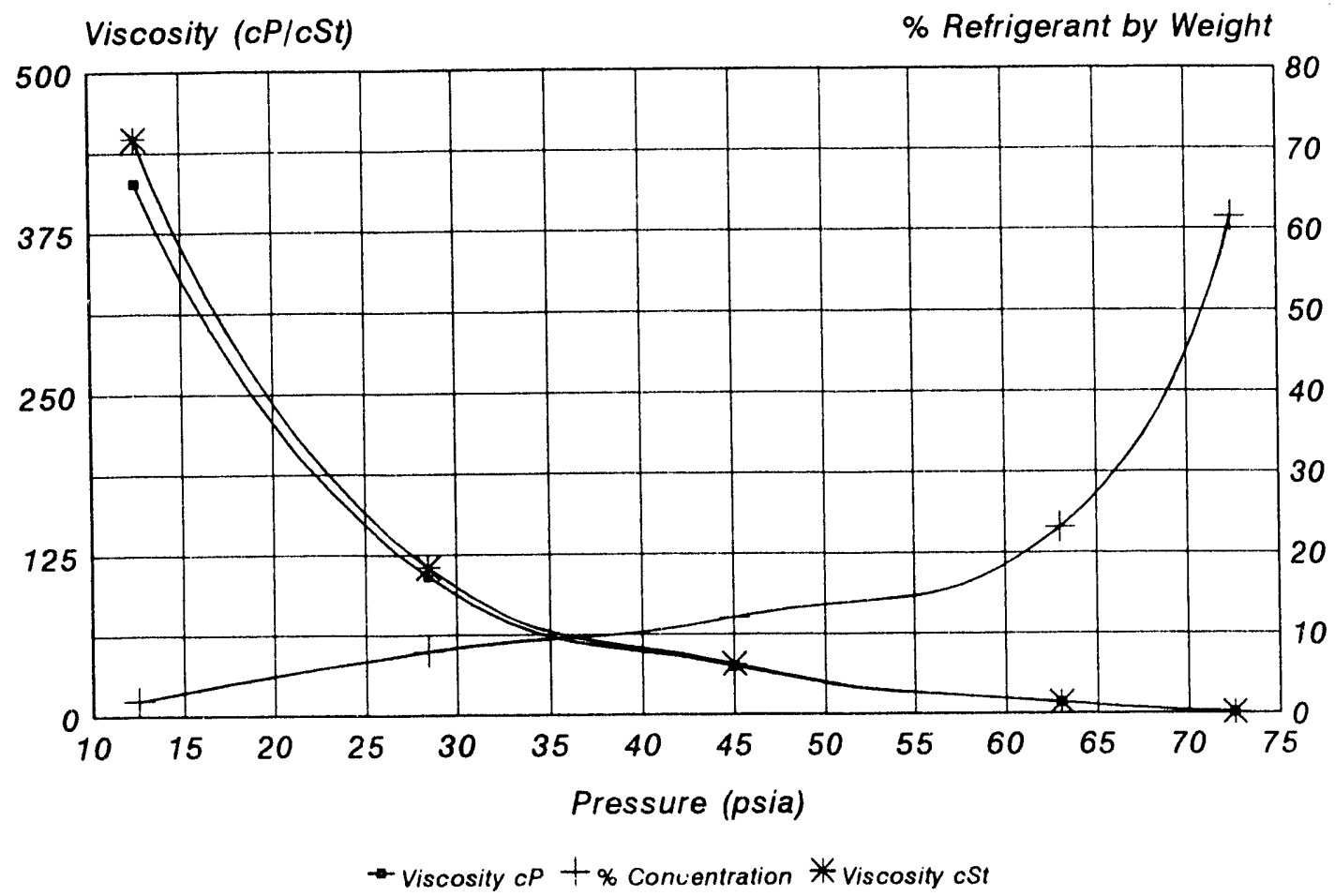

Viscosity via Gas Solubility Equilibrium

Oil degassed to 20 Millitorr

Viscosity and Gas Solubility

32 ISO VG Mineral Oil with HCFC-22 at $-20^{\circ} \mathrm{C}$

Figure B.8

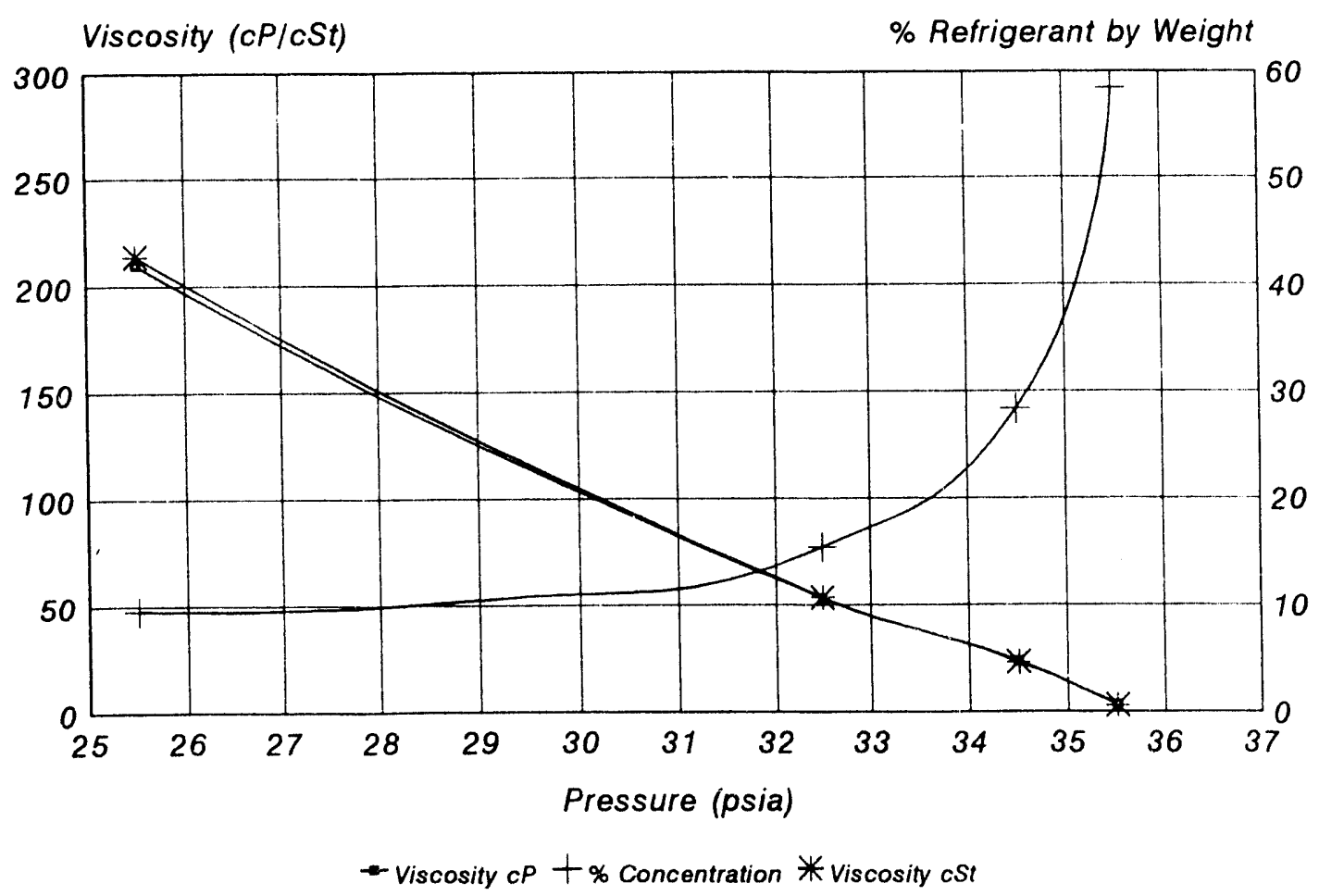




\section{Raw Data: Viscosity, Density, and Solubility 32 ISO VG Mineral Oil with HCFC-22 \\ Table B.1}

\begin{tabular}{|c|c|c|c|c|}
\hline \multicolumn{5}{|c|}{$\begin{array}{l}125.0^{\circ} \mathrm{C} \text { Temperature } \\
>500.0 \text { psia Saturation Pressure }\end{array}$} \\
\hline Density & Pressure & $\begin{array}{l}\text { \% Refrig. } \\
\text { Conc. }\end{array}$ & $\begin{array}{c}\text { Viscosity } \\
\text { cP }\end{array}$ & $\begin{array}{c}\text { Viscosity } \\
\text { cSt }\end{array}$ \\
\hline 0.8129 & 18.50 & 0.271 & 1.900 & 2.338 \\
\hline 0.8271 & 115.00 & 2.669 & 1.725 & 2.084 \\
\hline 0.8368 & 213.00 & 4.806 & 1.500 & 1.792 \\
\hline 0.8480 & 3.34 .00 & 8.379 & 1.345 & 1.586 \\
\hline 0.8592 & 450.00 & 11.134 & 1.225 & 1.426 \\
\hline
\end{tabular}

\begin{tabular}{|c|c|c|c|c|}
\hline $\begin{array}{l}40^{\circ} \mathrm{C} \\
222.4 \text { psia }\end{array}$ & $\begin{array}{l}\text { Temperature } \\
\text { Saturation } P\end{array}$ & essure & & \\
\hline Density & Pressure & $\begin{array}{c}\% \text { Refrig. } \\
\text { Conc. }\end{array}$ & $\begin{array}{c}\text { Viscosity } \\
\text { cP }\end{array}$ & $\begin{array}{c}\text { Viscosity } \\
\text { cSt }\end{array}$ \\
\hline 0.8809 & 12.00 & 1.615 & 21.987 & 24.958 \\
\hline 0.9042 & 69.00 & 5.071 & 10.630 & 11.758 \\
\hline 0.9303 & 128.25 & 5.878 & 5.185 & 5.574 \\
\hline 0.9565 & 168.00 & 18.977 & 2.690 & 2.813 \\
\hline 1.0268 & 27.75 & 38.002 & 0.938 & 0.918 \\
\hline
\end{tabular}

\begin{tabular}{|c|c|c|c|c|}
\hline $\begin{array}{l}100^{\circ} \mathrm{C} \\
>500 \text { psia }\end{array}$ & $\begin{array}{l}\text { Temperatur } \\
\text { Saturation } \mathrm{F}\end{array}$ & essure & & \\
\hline Density & Pressure & $\begin{array}{l}\text { \% Refrig. } \\
\text { Conc. }\end{array}$ & $\begin{array}{c}\text { Viscosity } \\
\text { cP }\end{array}$ & $\begin{array}{c}\text { Viscosity } \\
\text { cSt }\end{array}$ \\
\hline 0.8260 & 10.00 & 1.732 & 3.231 & 3.908 \\
\hline 0.8530 & 144.00 & 5.968 & 2.301 & 2.699 \\
\hline 0.8779 & 259.00 & 9.261 & 1.765 & 2.010 \\
\hline 0.8996 & 375.00 & 13.416 & 1.388 & 1.543 \\
\hline 0.9168 & 489.00 & 19.272 & 1.140 & 1.244 \\
\hline
\end{tabular}

\begin{tabular}{|r|r|r|r|r|}
\hline $\begin{array}{l}20^{\circ} \mathrm{C} \\
132.0 \text { psia }\end{array}$ & \multicolumn{2}{|c|}{$\begin{array}{l} \\
\text { Semperaturation Pressure }\end{array}$} \\
\hline Density & Pressure & $\begin{array}{r}\text { \% Refrig. } \\
\text { Conc. }\end{array}$ & $\begin{array}{c}\text { Viscosity } \\
\text { cP }\end{array}$ & $\begin{array}{c}\text { Viscosity } \\
\text { CSt }\end{array}$ \\
\hline 0.9004 & 9.00 & 2.346 & 72.070 & 80.603 \\
\hline 0.9221 & 44.00 & 5.619 & 28.453 & 30.856 \\
\hline 0.9445 & 78.00 & 11.573 & 11.495 & 12.171 \\
\hline 0.9811 & 113.00 & 21.107 & 3.839 & 3.913 \\
\hline 1.1060 & 132.00 & 55.534 & 0.608 & 0.550 \\
\hline
\end{tabular}

\begin{tabular}{|c|c|c|c|c|}
\hline $\begin{array}{l}80^{\circ} \mathrm{C} \\
>500 \text { psia }\end{array}$ & $\begin{array}{l}\text { Temperature } \\
\text { Saturation } \mathrm{Pr}\end{array}$ & essure & & \\
\hline Density & Pressure & $\begin{array}{c}\% \text { Refrig. } \\
\text { Conc. }\end{array}$ & $\begin{array}{c}\text { Viscosity } \\
\text { cP }\end{array}$ & $\begin{array}{c}\text { Viscosity } \\
\text { cSt }\end{array}$ \\
\hline 0.8360 & 20.00 & 1.590 & 4.982 & 5.959 \\
\hline 0.8610 & 155.20 & 5.336 & 3.403 & 3.954 \\
\hline 0.8980 & 248.00 & 12.237 & 1.958 & 1.279 \\
\hline 0.9330 & 405.00 & 22.825 & 1.133 & 1.215 \\
\hline
\end{tabular}

\begin{tabular}{|l|r|r|r|r|}
\hline $\begin{array}{l}0^{\circ} \mathrm{C} \\
72.2 \text { psia }\end{array}$ & \multicolumn{2}{|l|}{$\begin{array}{l}\text { Temperature } \\
\text { Saturation Pressure }\end{array}$} \\
\hline Density & Pressure & $\begin{array}{c}\text { \% Refrig. } \\
\text { Conc. }\end{array}$ & $\begin{array}{r}\text { Viscosity } \\
\mathrm{CP}\end{array}$ & $\begin{array}{r}\text { Viscosity } \\
\mathrm{cSt}\end{array}$ \\
\hline 0.9228 & 12.50 & 1.891 & 413.875 & 448.500 \\
\hline 0.9390 & 28.50 & 7.929 & 107.891 & 114.961 \\
\hline 0.9580 & 45.00 & 12.073 & 37.507 & 39.154 \\
\hline 1.0065 & 63.00 & 23.106 & 8.634 & 8.579 \\
\hline 1.1531 & 72.50 & 61.534 & 0.890 & 0.772 \\
\hline
\end{tabular}

\begin{tabular}{|c|c|c|c|c|}
\hline $\begin{array}{l}60^{\circ} \mathrm{C} \\
500 \text { psia }\end{array}$ & $\begin{array}{l}\text { Temperatur } \\
\text { Saturation } P\end{array}$ & essure & & \\
\hline Density & Pressure & $\begin{array}{l}\text { \% Refrig. } \\
\text { Conc. }\end{array}$ & $\begin{array}{c}\text { Viscosity } \\
\text { cP }\end{array}$ & $\begin{array}{c}\text { Viscosity } \\
\text { cSt }\end{array}$ \\
\hline 1.8502 & 18.75 & 1.406 & 9.158 & 10.775 \\
\hline 0.8929 & 97.50 & 6.389 & 5.514 & 6.176 \\
\hline 0.9146 & 171.00 & 11.057 & 3.307 & 3.616 \\
\hline 0.9437 & 260.00 & 21.928 & 1.689 & 1.791 \\
\hline 0.9878 & 332.50 & 35.500 & 0.849 & 0.860 \\
\hline
\end{tabular}

\begin{tabular}{|c|c|c|c|c|}
\hline $\begin{array}{l}-20^{\circ} \mathrm{C} \\
40.3 \text { psia }\end{array}$ & $\begin{array}{l}\text { Temperatur } \\
\text { Saturation } \mathrm{H}\end{array}$ & essure & & \\
\hline Density & Pressure & $\begin{array}{l}\% \text { Refrig. } \\
\text { Conc. }\end{array}$ & $\begin{array}{c}\text { Viscosity } \\
\text { CP }\end{array}$ & $\begin{array}{c}\text { Viscosity } \\
\text { cSt }\end{array}$ \\
\hline 0.9811 & 25.50 & 9.542 & 209.777 & 213.815 \\
\hline 0.9908 & 32.50 & 15.426 & 52.501 & 53.491 \\
\hline 1.0177 & 34.50 & 33.365 & 23.486 & 23.077 \\
\hline 1.1665 & 35.50 & 58.439 & 3.398 & 2.874 \\
\hline
\end{tabular}


APPENDIX C:

Viscosity, Solubility and Gas Fractionation of 32 ISO VG Mineral Oil at Various

Temperatures with R-502 


\section{Viscosity, Solubility and Gas Fractionation}

32 ISO VG Mineral Oil with R-502 at $125^{\circ} \mathrm{C}$

Figure C.1

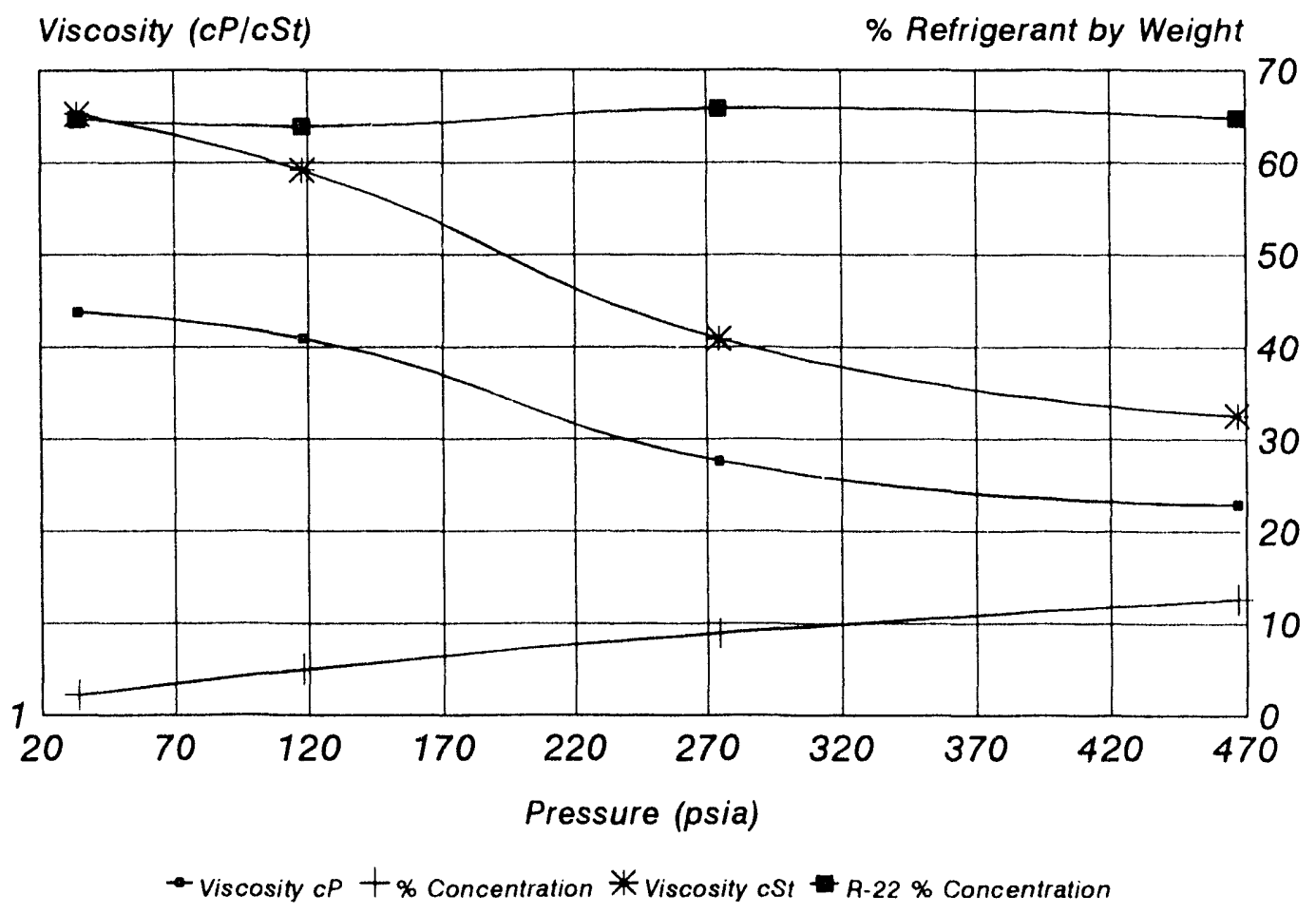

Viscosity via Gas Solubility Equilibrium Oil degassed to 20 Millitorr

\section{Viscosity, Solubility, and Gas Fractionation 32 ISO VG Mineral Oil with R-502 at $100^{\circ} \mathrm{C}$}

Figure $C .2$

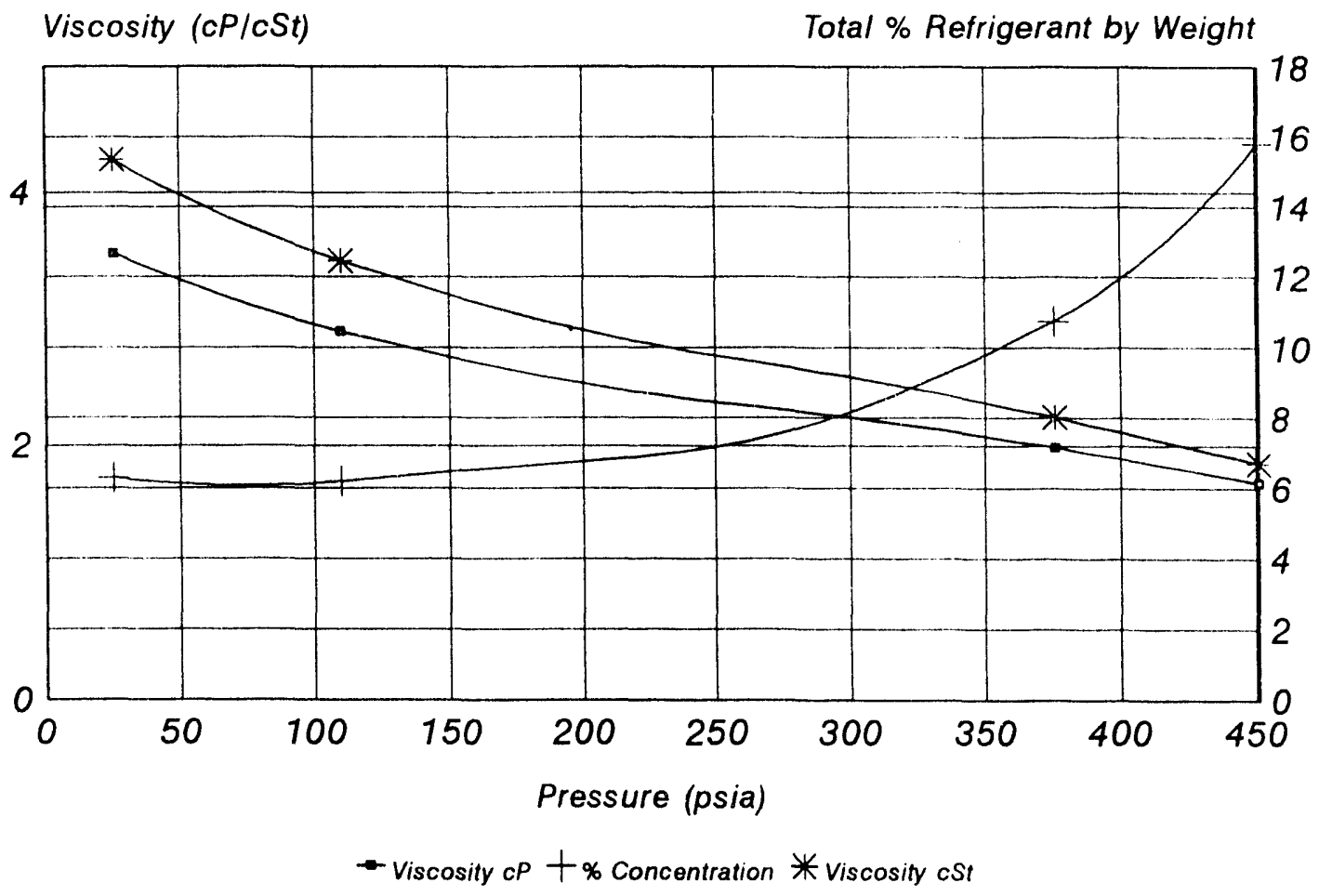




\section{Viscosity, Solubility, and Gas Fractionation}

32 ISO VG Mineral Oil with R-502 at $70^{\circ} \mathrm{C}$

Figure C. 3

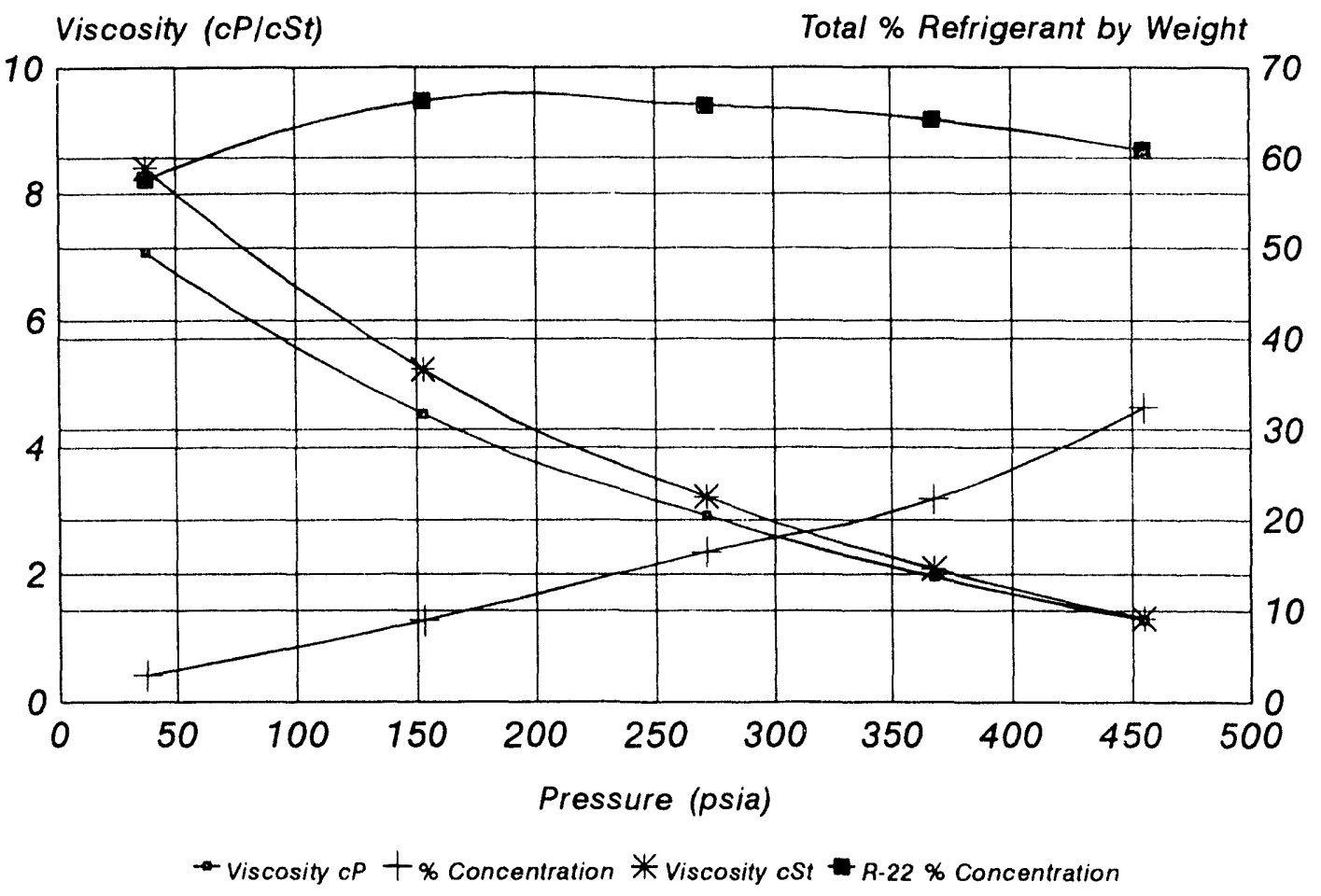

Viscosity via Gas Solubility Equilibrium

Oil degassed to 20 Millitorr

\section{Viscosity, Solubility, and Gas Fractionation}

32 ISO VG Mineral Oil with R-502 at $40^{\circ} \mathrm{C}$

Figure C.4

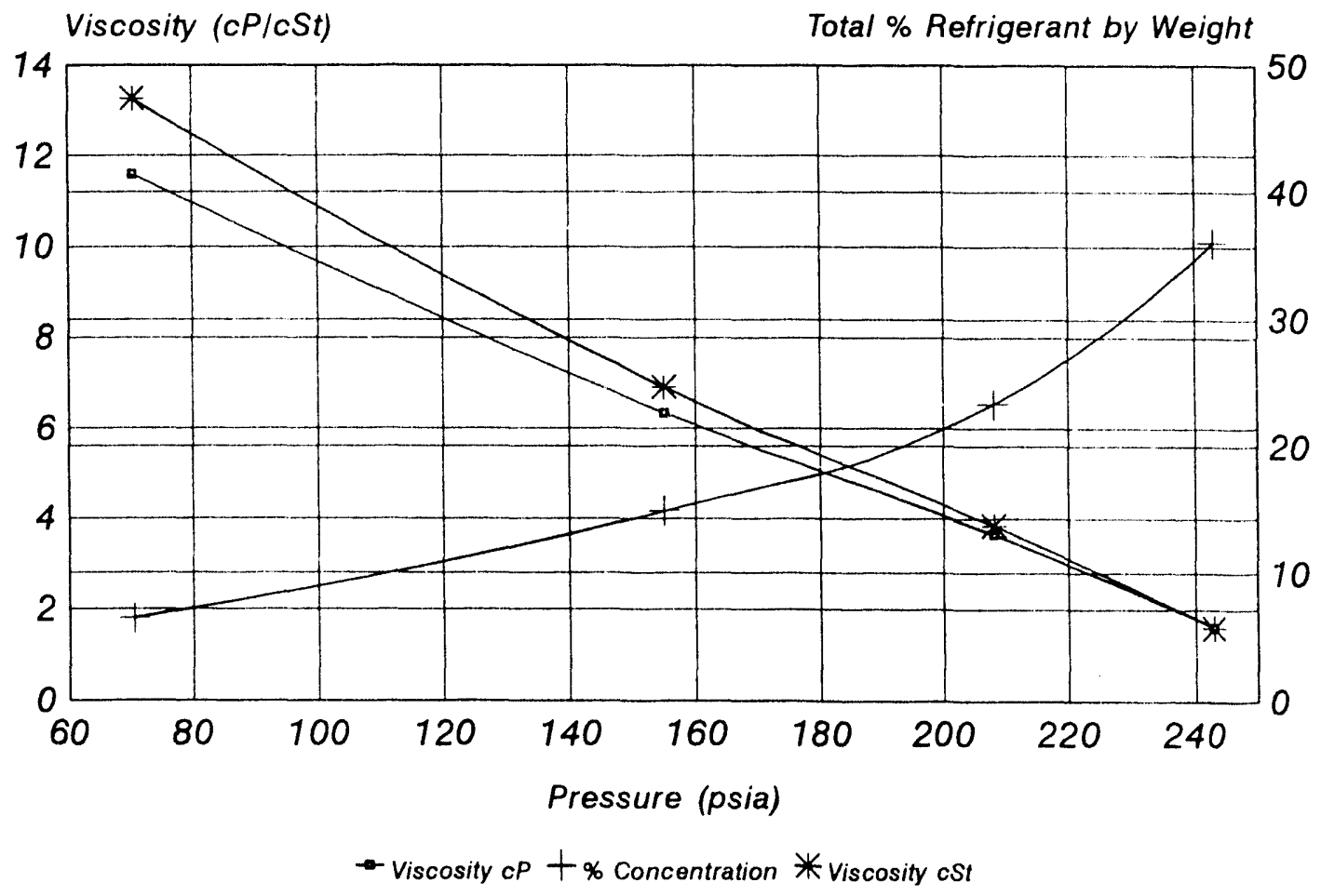




\section{Viscosity, Solubility, and Gas Fractionation}

32 ISO VG Mineral Oil with R-502 at $20^{\circ} \mathrm{C}$

Figure C.5

Viscosity (cP/cSt)

Total \% Refrigerant by Weight

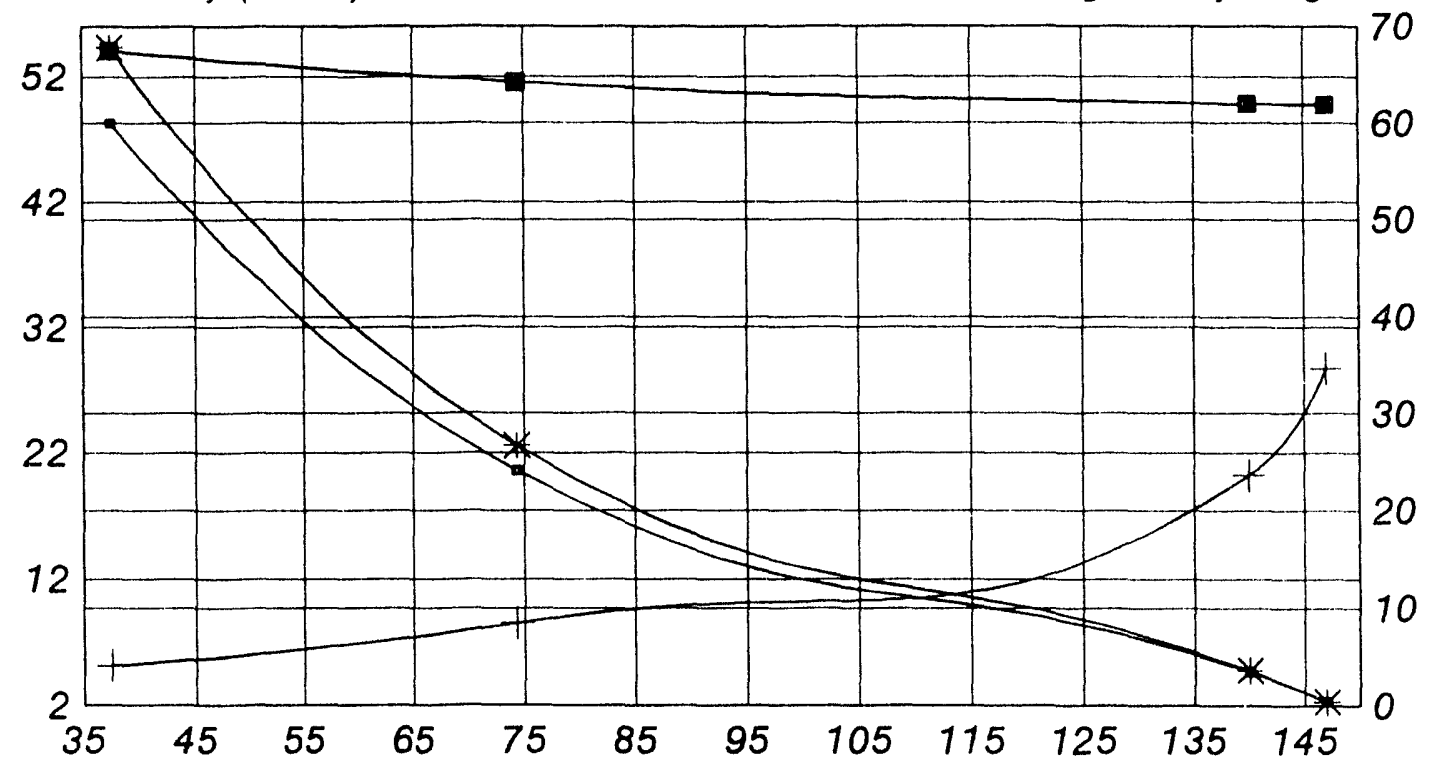

Pressure (psia)

$\rightarrow$ Viscosity $c P+\%$ Concentration $*$ Viscosity cSt $R-22 \%$ Concentration

Viscosity via Gas Solubility Equilibrium Oil degassed to 20 Millitorr

\section{Viscosity, Solubility, and Gas Fractionation} 32 ISO VG Mineral Oil with R-502 at $0^{\circ} \mathrm{C}$

Table C.6

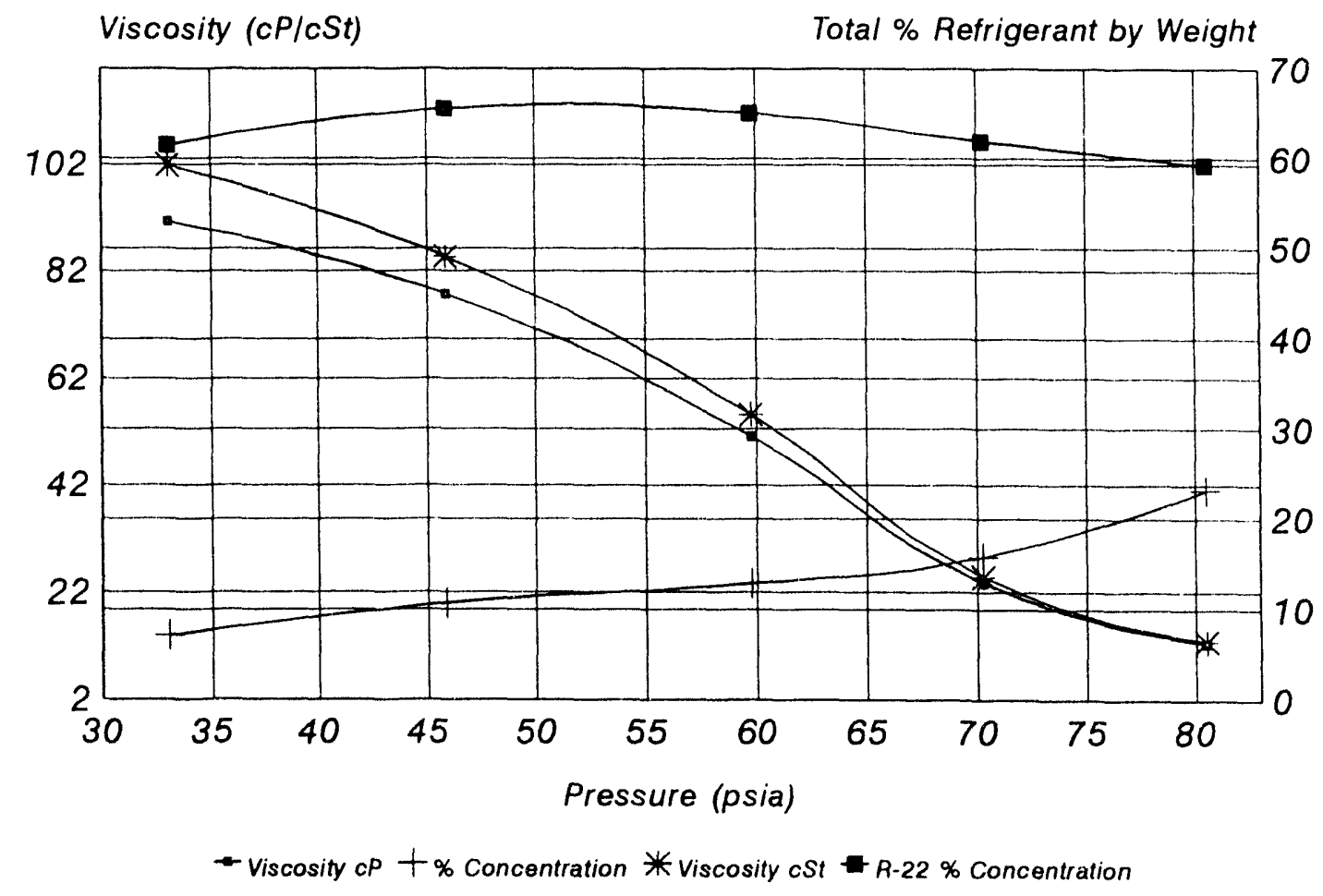


Viscosity, Solubility, and Gas Fractionation

32 ISO VG Mineral Oil with R-502 at $-10^{\circ} \mathrm{C}$

Table C.7

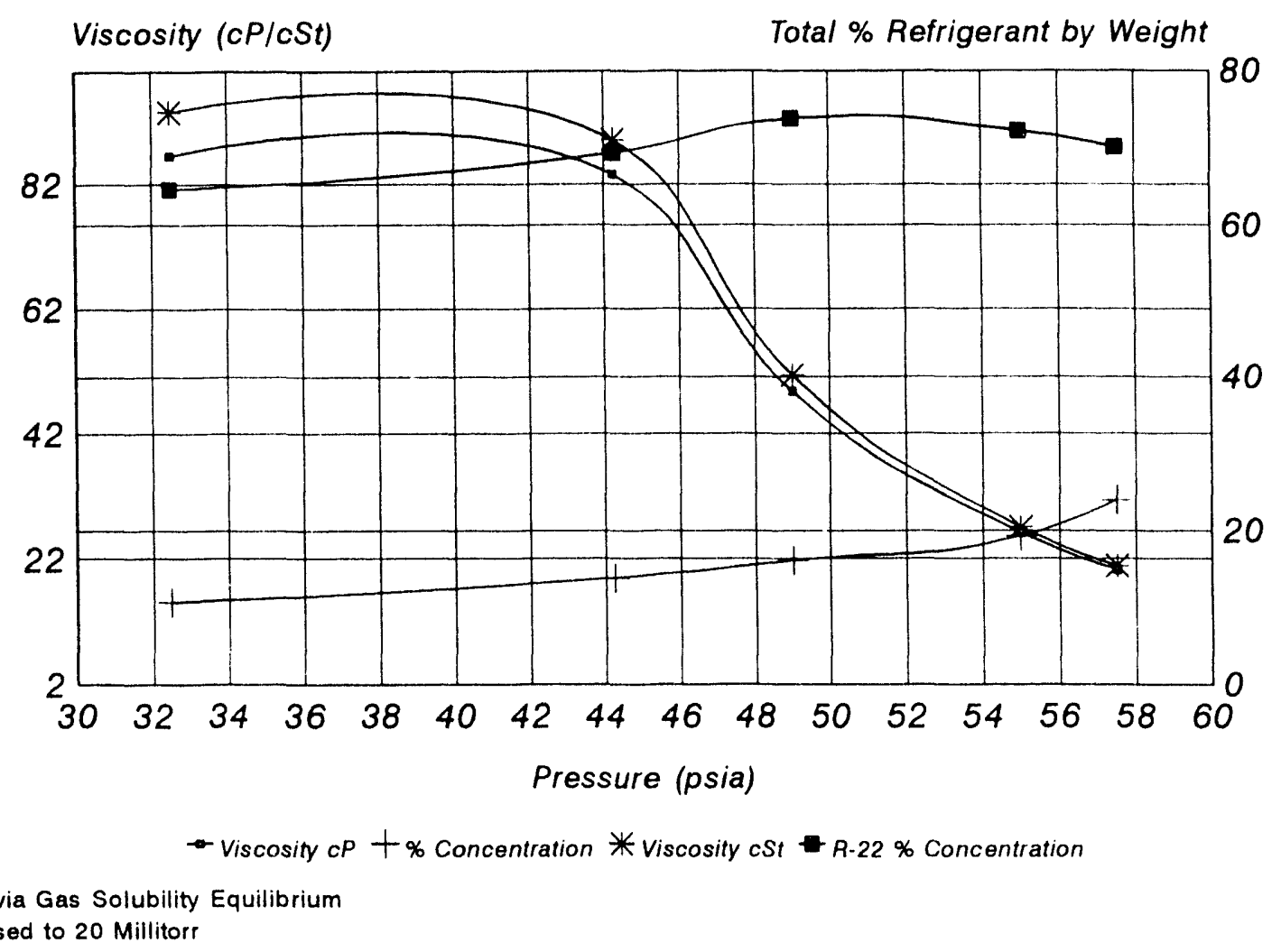




\section{Raw Data: Viscosity, Density, Solubility, and Gas Fractionation 32 ISO VG Mineral Oil with R-502 \\ Table C.1}

\begin{tabular}{|c|c|c|c|c|c|}
\hline \multicolumn{3}{|c|}{$\begin{array}{l}125.0^{\circ} \mathrm{C} \text { Temperature } \\
>500.0 \text { psia Saturation Pressure }\end{array}$} & \multirow[b]{2}{*}{$\begin{array}{l}\text { Viscosity } \\
\text { CP }\end{array}$} & \multirow[b]{2}{*}{$\begin{array}{l}\text { Viscosity } \\
\text { cSt }\end{array}$} & \multirow[b]{2}{*}{$\begin{array}{c}\% \\
R-22\end{array}$} \\
\hline Density & Pressure & $\begin{array}{l}\text { \% Refrig. } \\
\text { Conc. }\end{array}$ & & & \\
\hline 0.8073 & 34.75 & 2.175 & 1.938 & 2.400 & 66.100 \\
\hline 0.8273 & 118.00 & 4.930 & 1.877 & 2.269 & 63.900 \\
\hline 0.8488 & 274.50 & 8.926 & 1.593 & 1.876 & 66.400 \\
\hline 0.8785 & 466.75 & 12.671 & 1.492 & 1.733 & 65.900 \\
\hline
\end{tabular}

\begin{tabular}{|c|c|c|c|c|c|}
\hline $\begin{array}{l}20^{\circ} \mathrm{C} \\
147.9 \text { psia }\end{array}$ & $\begin{array}{l}\text { Temperatur } \\
\text { Saturation } P\end{array}$ & essure & & & \\
\hline Density & Pressure & $\begin{array}{l}\% \text { Refrig. } \\
\text { Conc. }\end{array}$ & $\begin{array}{c}\text { Viscosity } \\
\text { cP }\end{array}$ & $\begin{array}{c}\text { Viscosity } \\
\text { cSt }\end{array}$ & $\begin{array}{c}\% \\
R-22\end{array}$ \\
\hline 0.8889 & 37.50 & 4.083 & 48.295 & 54.331 & 67.50 \\
\hline 0.9124 & 74.50 & 8.436 & 20.602 & 22.579 & 64.25 \\
\hline 0.9827 & 140.00 & 23.638 & 4.706 & 4.789 & 62.00 \\
\hline 1.0286 & 147.00 & 34.676 & 2.536 & 2.293 & 618 \\
\hline
\end{tabular}

\begin{tabular}{|c|c|c|c|c|c|}
\hline $\begin{array}{l}80^{\circ} \mathrm{C} \\
>500 \text { psia }\end{array}$ & $\begin{array}{l}\text { Temperatur } \\
\text { Saturation } P\end{array}$ & essure & & & \\
\hline Density & Pressure & $\begin{array}{l}\% \text { Refrig. } \\
\text { Conc. }\end{array}$ & $\begin{array}{c}\text { Viscosity } \\
\text { cP }\end{array}$ & $\begin{array}{c}\text { Viscosity } \\
\text { cSt }\end{array}$ & $\begin{array}{c}\% \\
R-22\end{array}$ \\
\hline 0.8259 & 25.00 & 6.295 & 4.263 & 4.263 & 66.100 \\
\hline 0.8399 & 110.00 & 6.189 & 3.460 & 3.460 & 63.900 \\
\hline 0.8925 & 375.50 & 10.755 & 2.232 & 2.232 & 66.400 \\
\hline 0.9176 & 451.00 & 15.819 & 1.863 & 1.863 & 65.900 \\
\hline
\end{tabular}

\begin{tabular}{|c|c|c|c|c|c|}
\hline $\begin{array}{l}0^{\circ} \mathrm{C} \\
83.1 \text { psia }\end{array}$ & $\begin{array}{l}\text { Temperatur } \\
\text { Saturation }\end{array}$ & essure & & & \\
\hline Density & Pressure & $\begin{array}{c}\% \text { Refrig. } \\
\text { Conc. }\end{array}$ & $\begin{array}{c}\text { Viscosity } \\
\mathrm{cP}\end{array}$ & $\begin{array}{c}\text { Viscosity } \\
\text { cSt }\end{array}$ & $\begin{array}{c}\% \\
R-22\end{array}$ \\
\hline 0.8962 & 33.00 & 7.073 & 101.942 & 101.942 & 61.50 \\
\hline 0.9169 & 45.90 & 10.664 & 84.659 & 84.659 & 65.25 \\
\hline 0.9258 & 59.75 & 12.851 & 55.281 & 30.281 & 65.10 \\
\hline 0.9539 & 70.25 & 15.755 & 24.874 & 55.281 & 61.95 \\
\hline 0.9728 & 80.50 & 23.191 & 12.905 & 24.874 & 59.30 \\
\hline
\end{tabular}

\begin{tabular}{|c|c|c|c|c|c|}
\hline \multicolumn{3}{|c|}{$\begin{array}{ll}70^{\circ} \mathrm{C} & \text { Temperature } \\
467.67 \text { psia } & \text { Saturation Pressure }\end{array}$} & \multirow[b]{2}{*}{$\begin{array}{c}\text { Viscosity } \\
\text { cP }\end{array}$} & \multirow[b]{2}{*}{$\begin{array}{c}\text { Viscosity } \\
\text { cSt }\end{array}$} & \multirow[b]{2}{*}{$\begin{array}{c}\% \\
R-22\end{array}$} \\
\hline Density & Pressure & $\begin{array}{l}\% \text { Refrig. } \\
\text { Conc. }\end{array}$ & & & \\
\hline 0.8414 & 37.00 & 2.884 & 7.080 & 8.409 & 57.600 \\
\hline 0.8653 & 153.00 & 8.888 & 4.530 & 5.232 & 66.300 \\
\hline 0.9087 & 271.00 & 16.452 & 2.927 & 3.221 & 65.800 \\
\hline 0.9391 & 367.50 & 22.332 & 1.959 & 2.086 & 64.000 \\
\hline 0.9835 & 455.00 & 32.430 & 1.284 & 1.305 & 60.850 \\
\hline
\end{tabular}

\begin{tabular}{|c|c|c|c|c|c|}
\hline $\begin{array}{l}-10^{\circ} \mathrm{C} \\
60.1 \text { psia }\end{array}$ & $\begin{array}{l}\text { Temperatur } \\
\text { Saturation } P\end{array}$ & essure & & & \\
\hline Density & Pressure & $\begin{array}{l}\text { \% Refrig. } \\
\text { Conc. }\end{array}$ & $\begin{array}{c}\text { Viscosity } \\
\text { cP }\end{array}$ & $\begin{array}{c}\text { Viscosity } \\
\text { cSt }\end{array}$ & $\begin{array}{c}\% \\
R-22\end{array}$ \\
\hline 0.9255 & 32.50 & 10.708 & 86.521 & 93.536 & 64.60 \\
\hline 0.9265 & 40.75 & 10.544 & 123.132 & 132.903 & 62.85 \\
\hline 0.9384 & 44.25 & 13.822 & 83.596 & 89.091 & 69.9 \\
\hline 0.9494 & 49.00 & 16.106 & 48.671 & 51.264 & 73.85 \\
\hline 0.9687 & 55.00 & 19.303 & 26.584 & 27.021 & 72.30 \\
\hline 0.9708 & 57.50 & 20.286 & 20.286 & 20.895 & 70.20 \\
\hline
\end{tabular}

\begin{tabular}{|c|c|c|c|c|c|}
\hline $\begin{array}{l}40^{\circ} \mathrm{C} \\
243.2 \text { psia }\end{array}$ & $\begin{array}{l}\text { Temperatur } \\
\text { Saturation } \mathrm{P}\end{array}$ & essure & & & \\
\hline Density & Pressure & $\begin{array}{l}\% \text { Refrig. } \\
\text { Conc. }\end{array}$ & $\begin{array}{c}\text { Viscosity } \\
\mathrm{cP}\end{array}$ & $\begin{array}{c}\text { Viscosity } \\
\text { cSt }\end{array}$ & $\begin{array}{c}\% \\
R-22\end{array}$ \\
\hline 0.8747 & 70.50 & 6.432 & 11.599 & 13.260 & 59.550 \\
\hline 0.9183 & 155.00 & 14.889 & 6.348 & 6.913 & 56.600 \\
\hline 0.9487 & 208.00 & 23.358 & 36.500 & 3.650 & 60.800 \\
\hline 1.0027 & 243.00 & 36.055 & 1.613 & 1.609 & 59.450 \\
\hline
\end{tabular}


APPENDIX D:

Viscosity, Density and Gas Solubility of 32 ISO VG Mixed Acid Polyolester at Various Temperatures with HFC-134a 


\section{Viscosity and Gas Solubility \\ 32 ISO VG Mixed Acid Polyolester With R-134a at $125^{\circ} \mathrm{C}$ \\ Figure D.1}

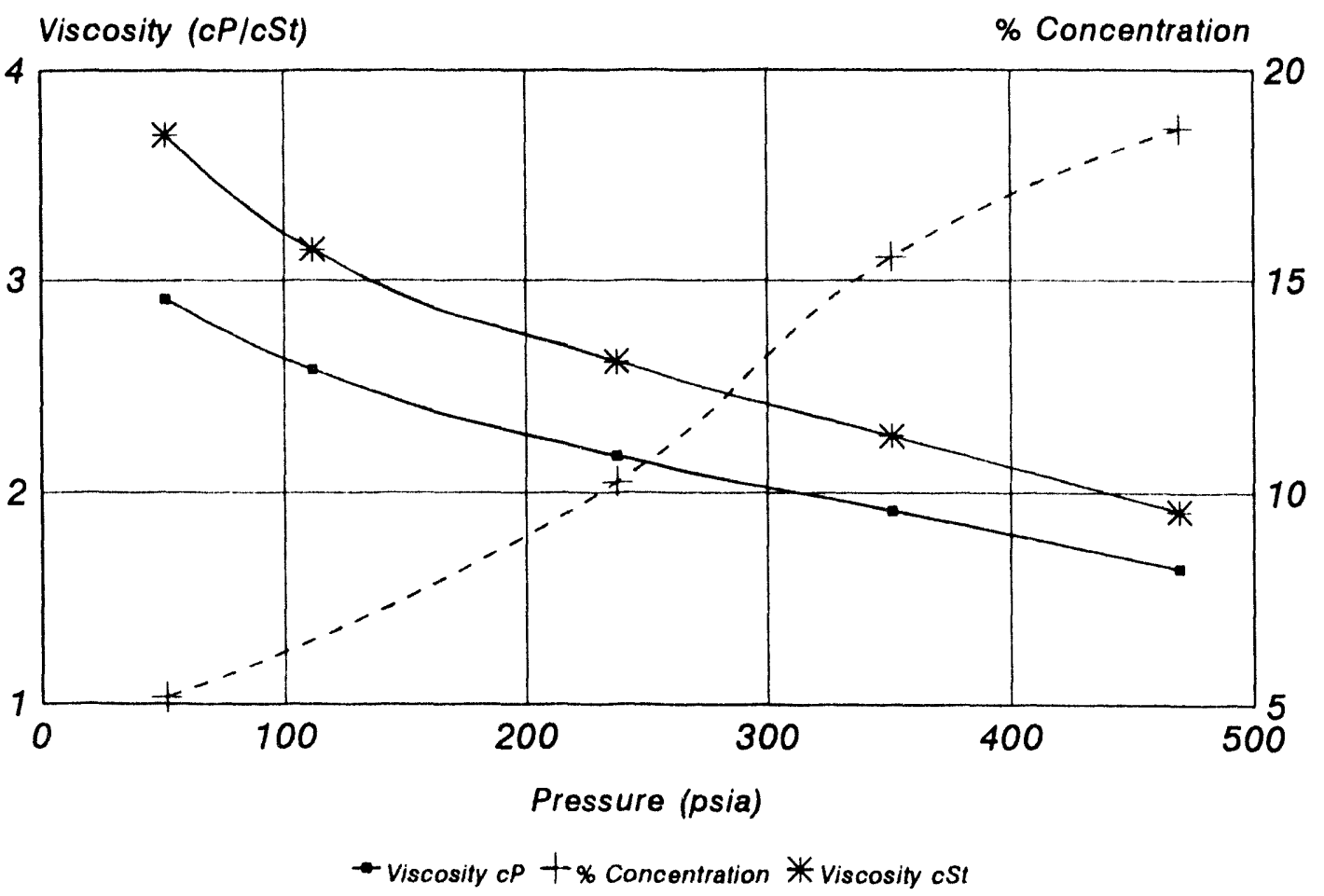

Viscosity via Gas Solubility Equilibrium Oil degassed to 20 Millitorr

\section{Viscosity and Gas Solubility}

32 ISO VG Mixed Acid Polyolester with R-134a at $100^{\circ} \mathrm{C}$

Figure $D .2$

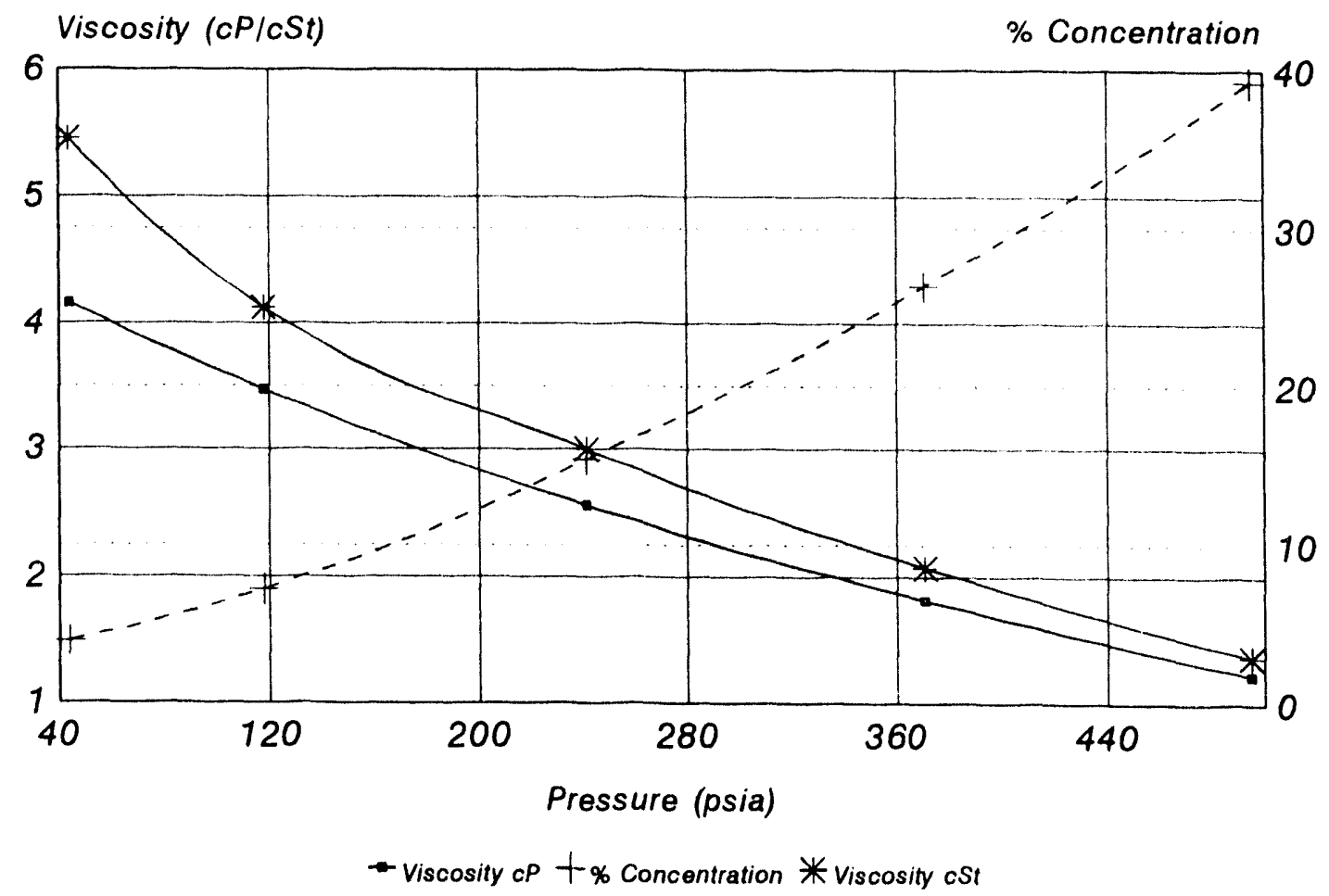




\section{Viscosity and Gas Solubility}

32 ISO VG Mixed Acid Polyolester with R-134a at $80^{\circ} \mathrm{C}$

Figure D.3

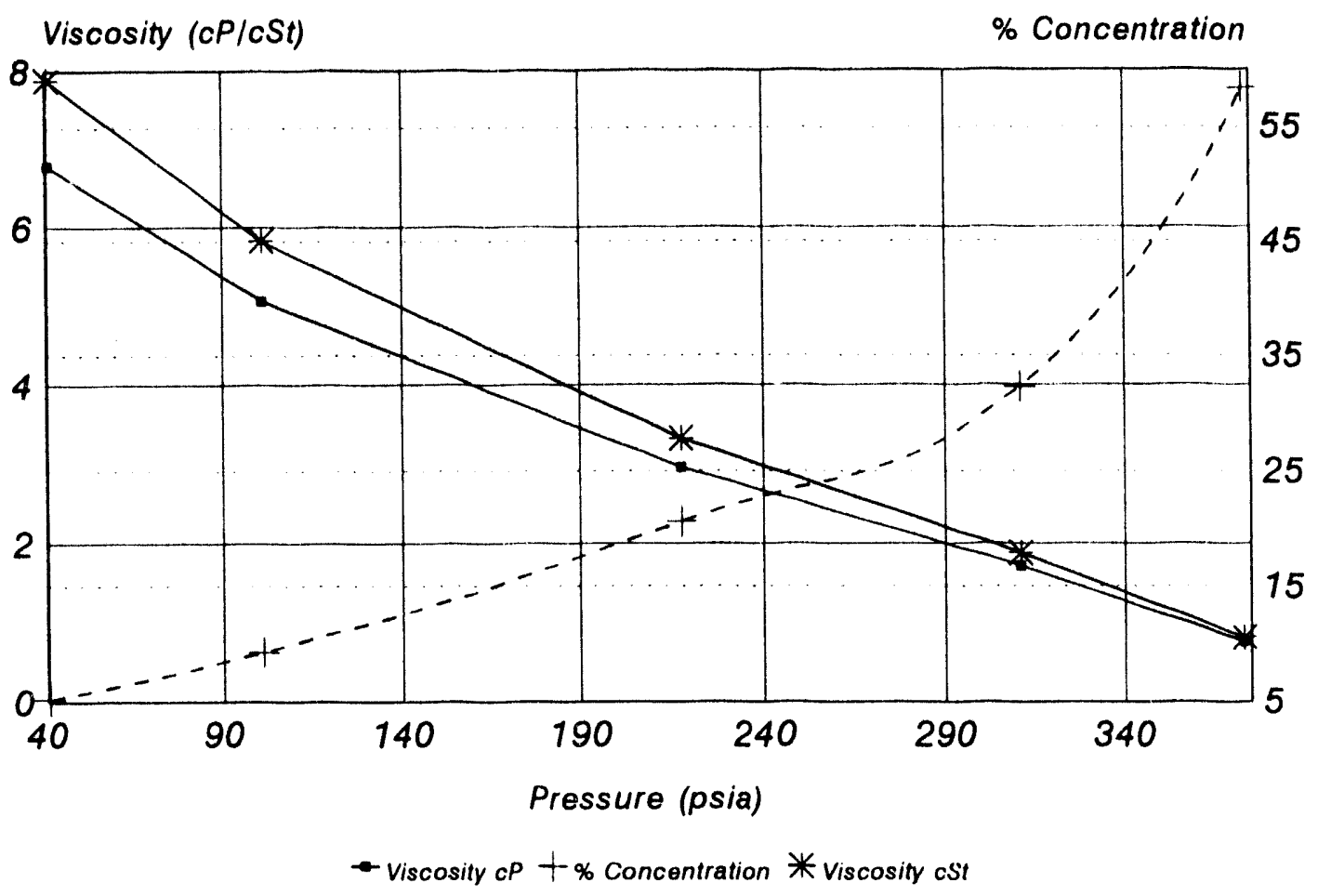

Viscosity via Gas Solubility Equilibrium

Oil degassed to 20 Millitorr

Viscosity and Gas Solubility

32 ISO VG Mixed Acid Polyolester with R-134a at $60^{\circ} \mathrm{C}$

Figure 0.4

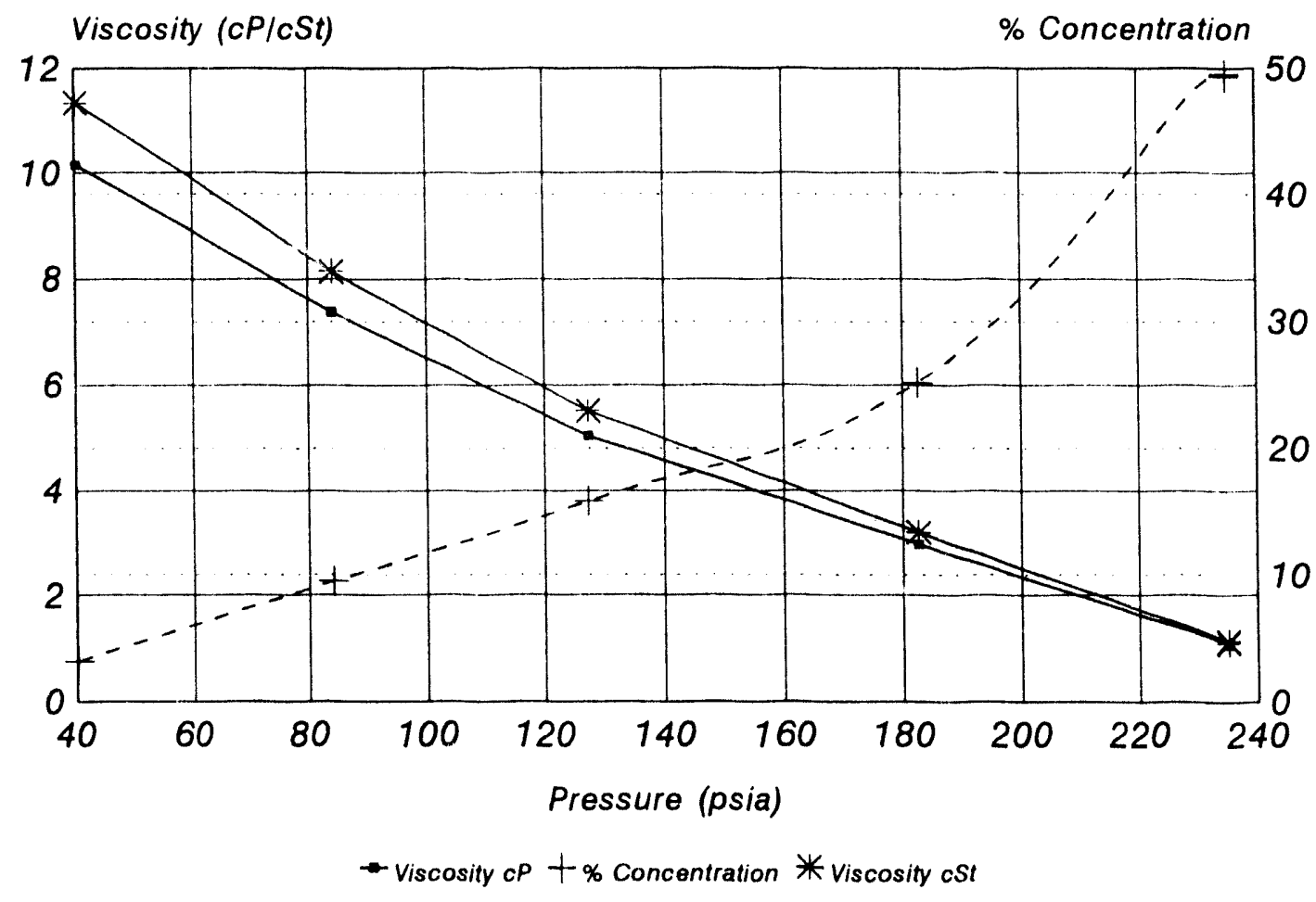




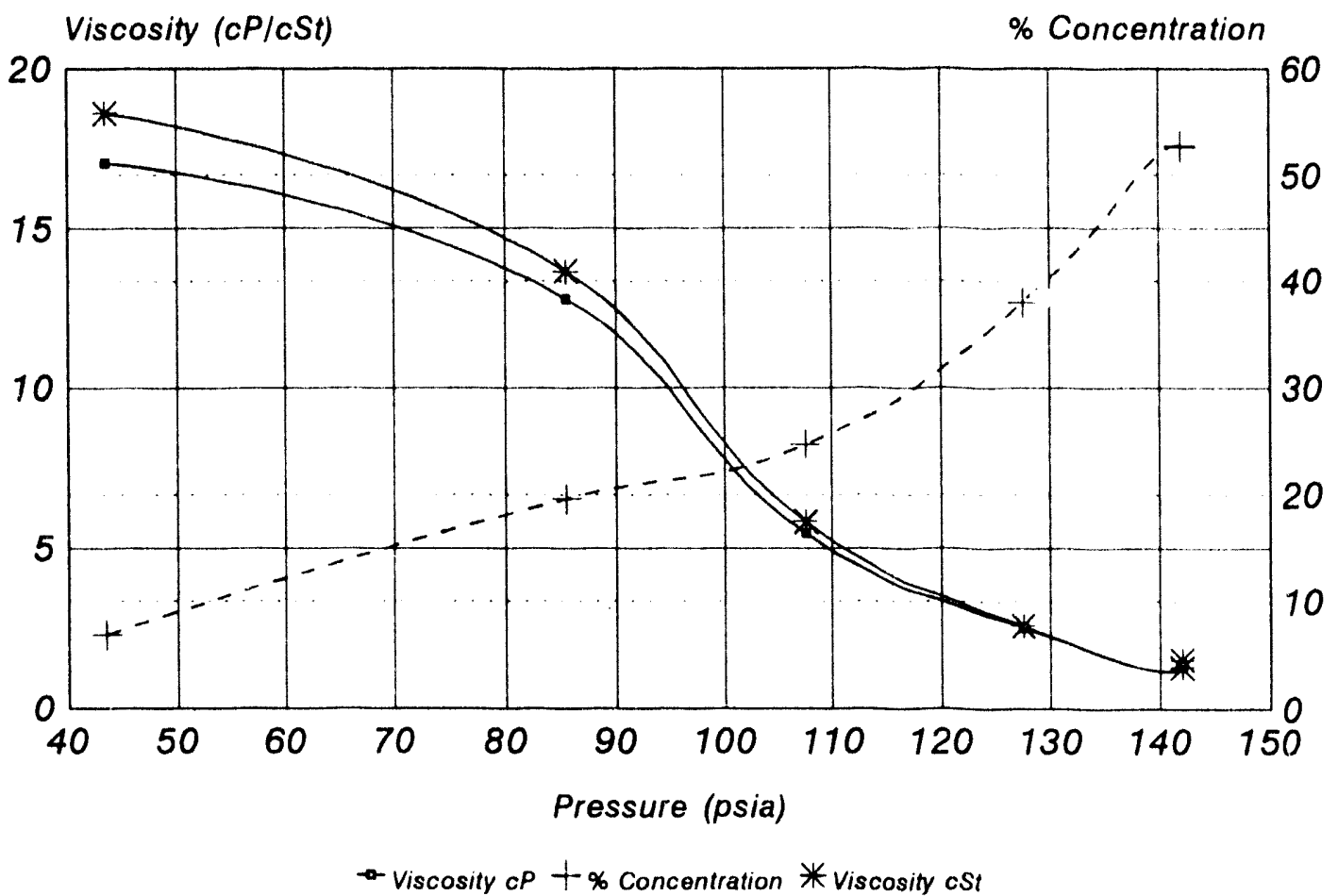

Viscosity via Gas Solubility Equilibrium Oil degassed to 20 Millitorr

Viscosity and Gas Solubility

32 ISO VG Mixed Acid Polyolester with R-134a at $20^{\circ} \mathrm{C}$

Figure D.6

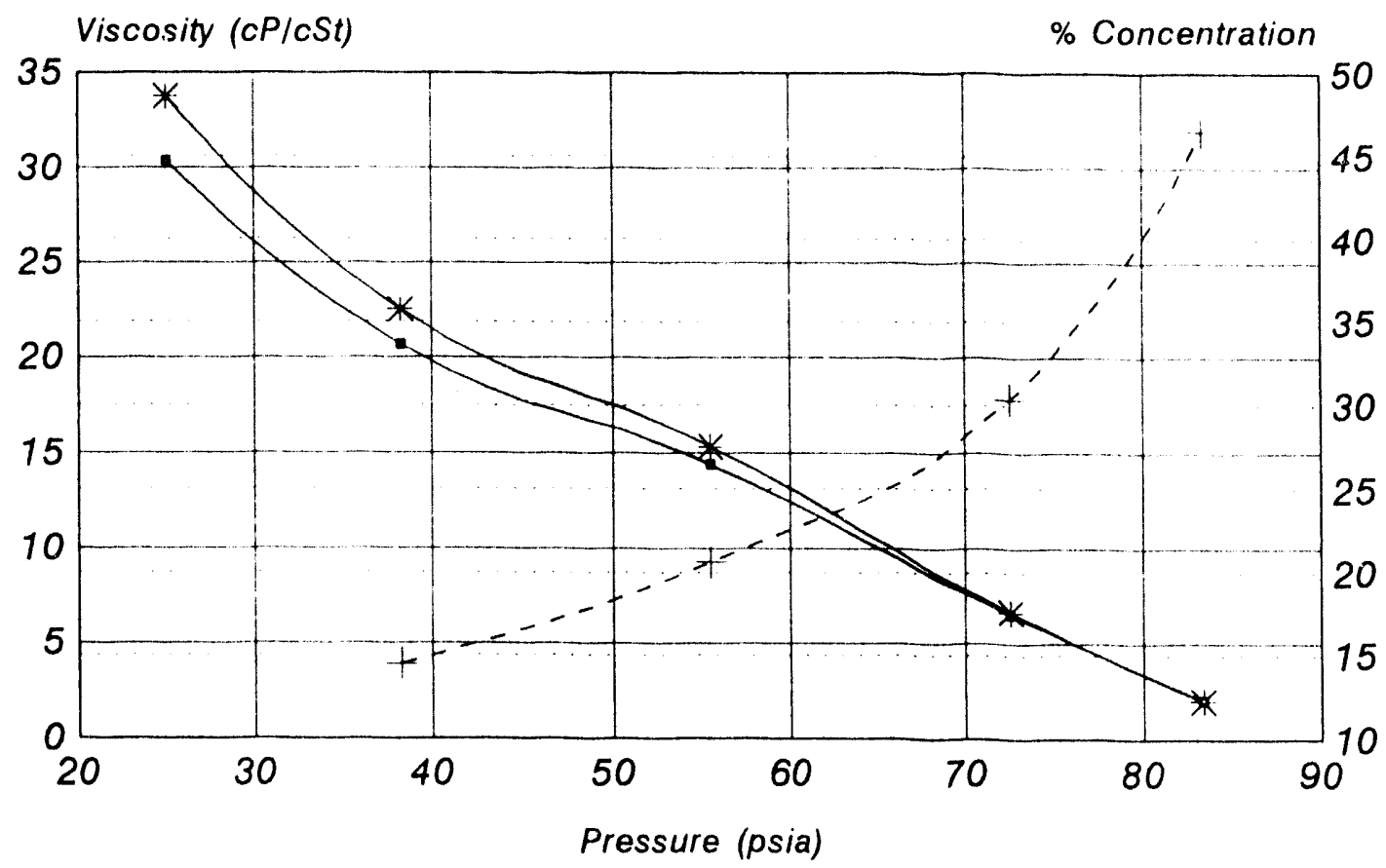

- Viscosity cP + \% Concentration * Viscosity cSt 


\section{Viscosity and Gas Solubility}

32 ISO VG Mixed Acid Polyolester with R-134a at $0^{\circ} \mathrm{C}$

Figure D.7

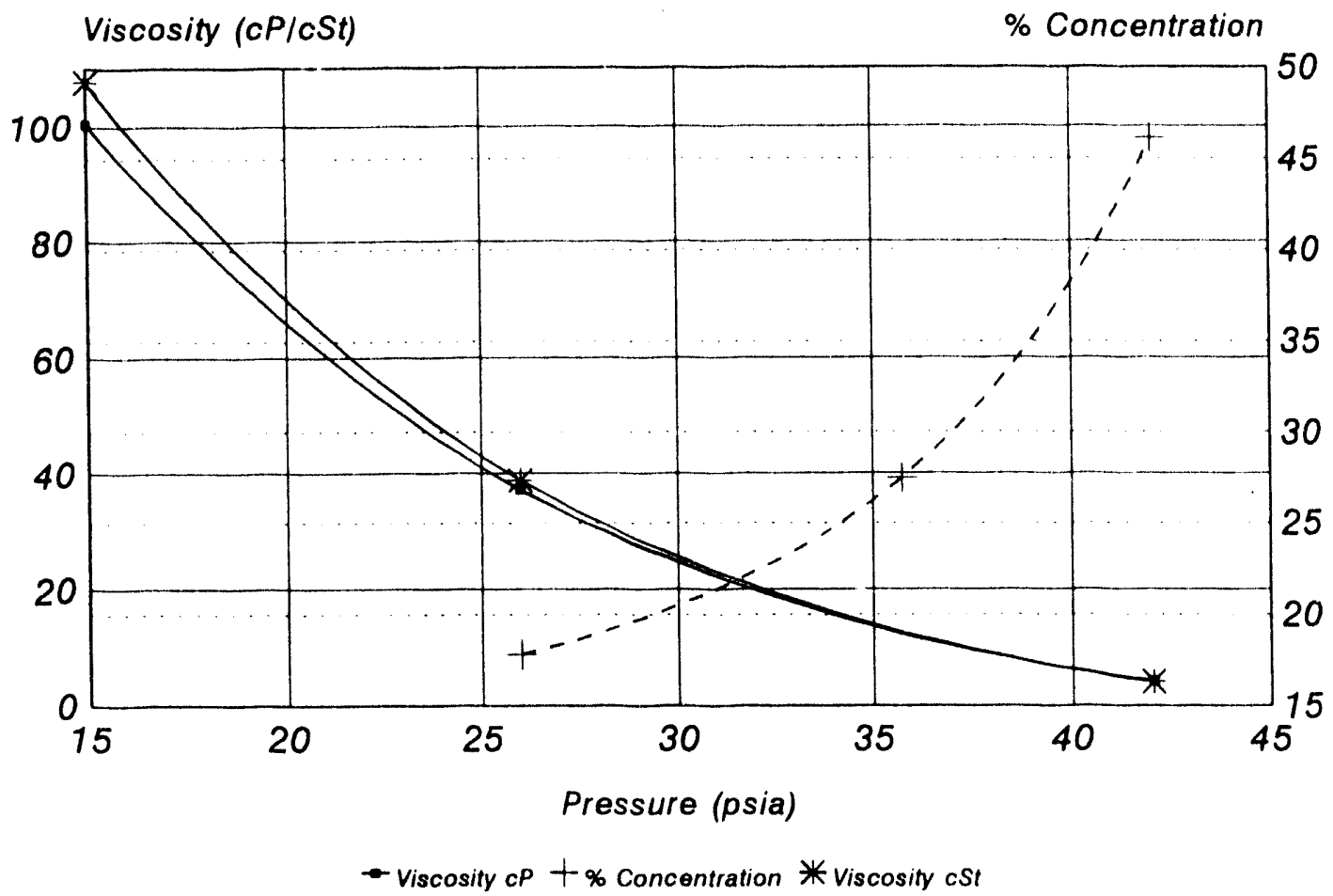

Viscosity via Gas Solubility Equilibrium

Oil degassed to 20 Millitorr

Viscosity and Gas Solubility

32 ISO VG Mixed Acid Polyolester with R-134a at $-15.0^{\circ} \mathrm{C}$

Figure $D .8$

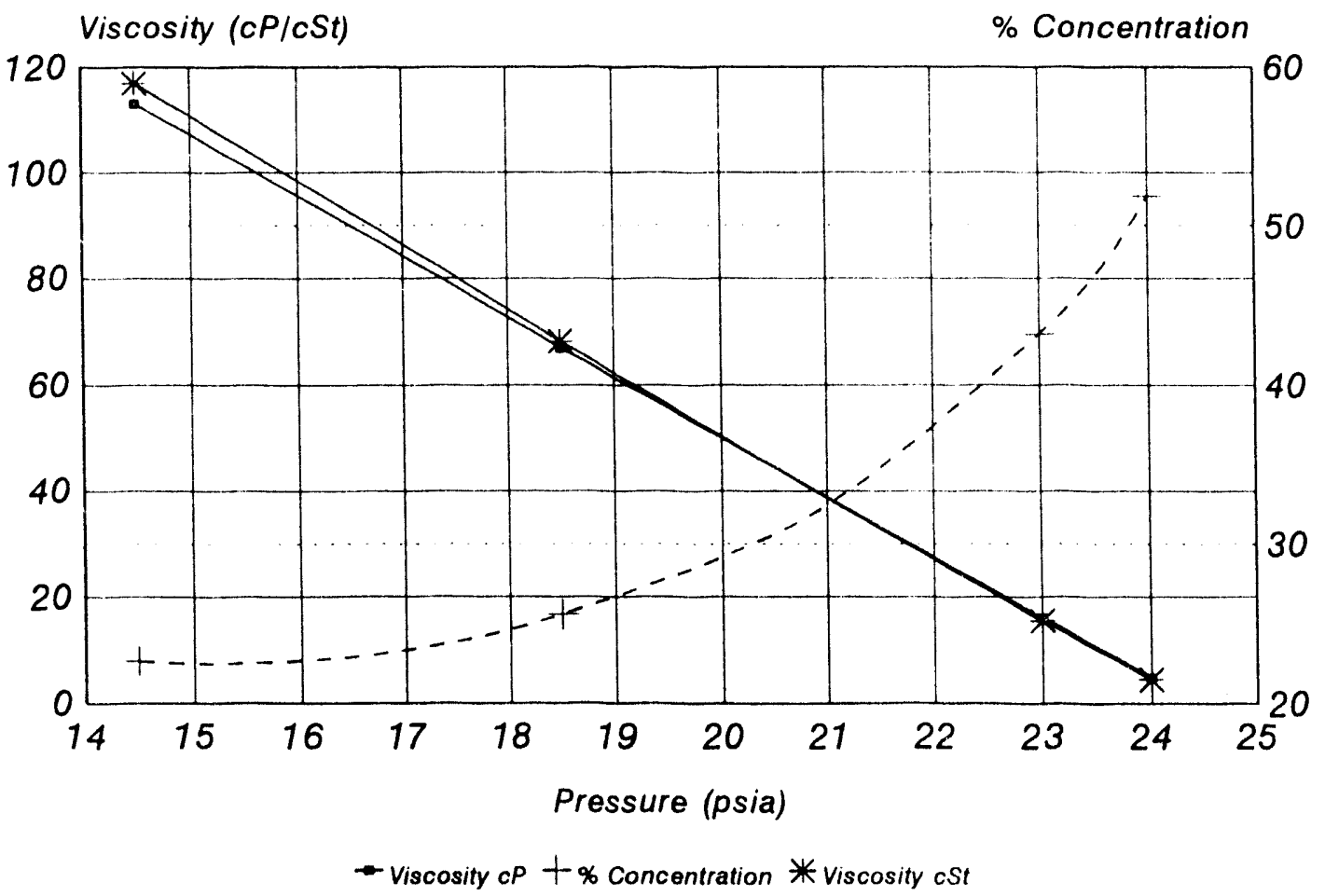




\section{Viscosity and Gas Solubility}

32 ISO VG Mixed Acid Polyolester with R-134a at $-30.0^{\circ} \mathrm{C}$

Figure D.9

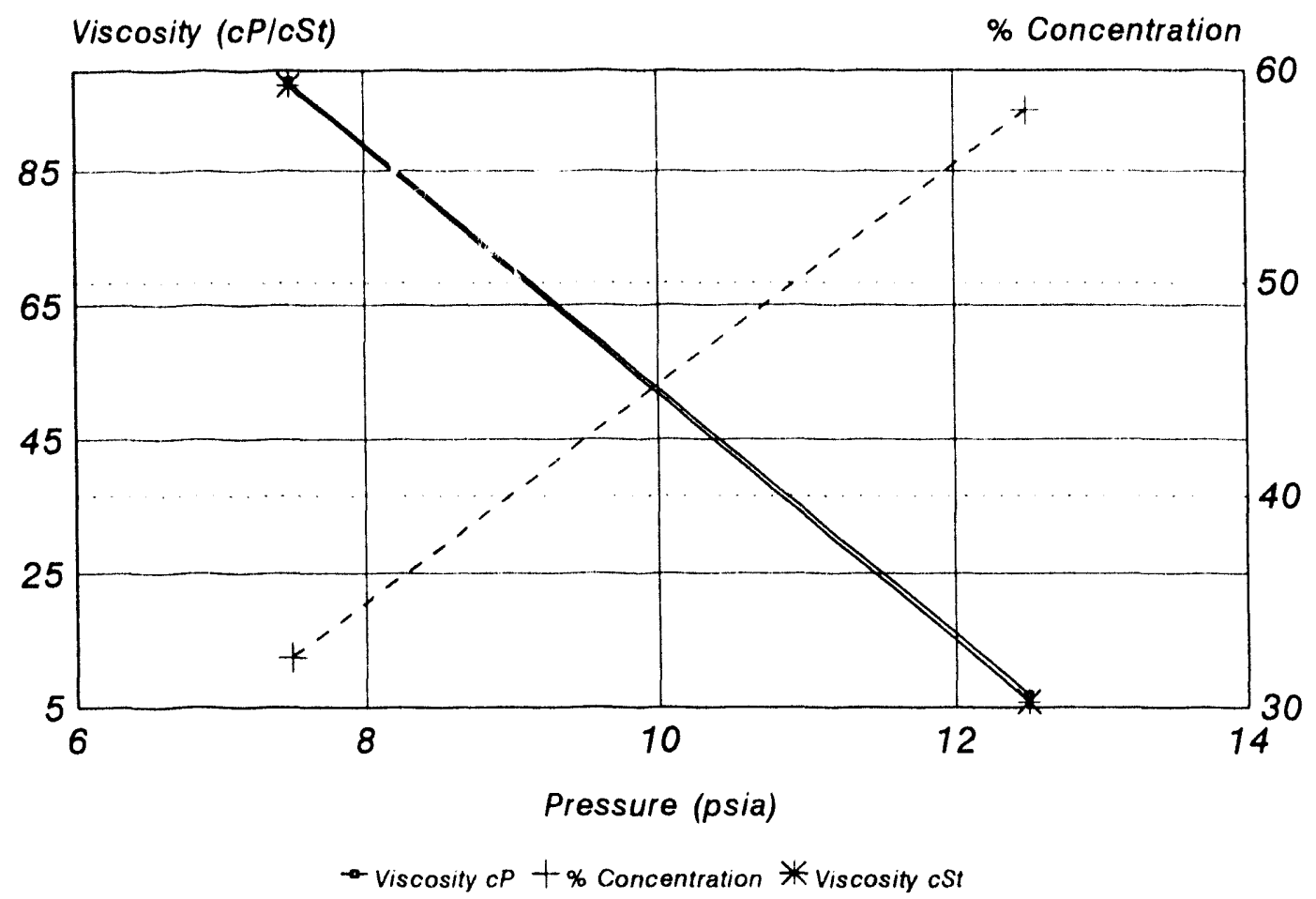

Viscosity via Gas Solubility Equilibrium

Oil degassed to 20 Millitorr 


\section{Raw Data: Viscosity, Density, and Gas Solubility 32 ISO VG Mixed Acid Polyolester with HFC-134a \\ Table D.1}

\begin{tabular}{|c|c|c|c|c|}
\hline \multicolumn{2}{|c|}{$\begin{array}{l}\text { Temperature: } 125.0^{\circ} \mathrm{C} \\
\text { Max. Pressure: } 500.0^{\circ}\end{array}$} & \multirow[b]{2}{*}{$\begin{array}{l}\text { \% Refrig. } \\
\text { Conc. }\end{array}$} & \multirow[b]{2}{*}{$\begin{array}{l}\text { Viscosity } \\
\text { cP }\end{array}$} & \multirow[b]{2}{*}{$\begin{array}{l}\text { Viscosity } \\
\text { cSt }\end{array}$} \\
\hline Density & Pressure & & & \\
\hline 0.7906 & 51.00 & 5.16 & 2.91 & 3.69 \\
\hline 0.8198 & 111.25 & 5.40 & 2.58 & 3.15 \\
\hline 0.8298 & 238.00 & 10.25 & 2.17 & 2.62 \\
\hline 0.8455 & 351.25 & 15.57 & 1.92 & 2.27 \\
\hline 0.8598 & 469.00 & 18.02 & 1.64 & 1.91 \\
\hline
\end{tabular}

\begin{tabular}{|c|c|c|c|c|}
\hline \multicolumn{2}{|c|}{$\begin{array}{l}\text { Temperature: } 20.0^{\circ} \mathrm{C} \\
\text { Sat. Pressure: } 83.38 \text { psia }\end{array}$} & & & \\
\hline Density & Pressure & $\begin{array}{l}\text { \% Refrig. } \\
\text { Conc. }\end{array}$ & $\begin{array}{c}\text { Viscosity } \\
\text { cP }\end{array}$ & $\begin{array}{l}\text { Viscosity } \\
\text { cSt }\end{array}$ \\
\hline 0.8997 & 25.00 & 19.82 & 30.36 & 33.75 \\
\hline 0.9183 & 38.25 & 14.47 & 20.65 & 22.49 \\
\hline 0.9397 & 55.50 & 20.61 & 14.41 & 15.33 \\
\hline 0.981 & 72.50 & 30.36 & 6.52 & 6.64 \\
\hline 1.0281 & 83.38 & 46.50 & 2.06 & 2.00 \\
\hline
\end{tabular}

\begin{tabular}{|c|c|c|c|c|}
\hline \multicolumn{2}{|c|}{$\begin{array}{l}\text { Temperature: } 100.0^{\circ} \mathrm{C} \\
\text { Max. Pressure: } 500.0^{\circ}\end{array}$} & \multirow[b]{2}{*}{$\begin{array}{l}\text { \% Refrig. } \\
\text { Conc. }\end{array}$} & \multirow[b]{2}{*}{$\begin{array}{c}\text { Viscosity } \\
\text { cP }\end{array}$} & \multirow[b]{2}{*}{$\begin{array}{c}\text { Viscosity } \\
\text { cSt }\end{array}$} \\
\hline Density & Pressure & & & \\
\hline 0.762 & 44.00 & 3.92 & 4.16 & 5.46 \\
\hline 0.8426 & 117.50 & 7.20 & 3.47 & 4.12 \\
\hline 0.8533 & 241.38 & 15.35 & 2.58 & 3.00 \\
\hline 0.8760 & 371.00 & 26.38 & 1.82 & 2.07 \\
\hline 0.894 & 495.00 & 39.29 & 1.22 & 1.37 \\
\hline
\end{tabular}

\begin{tabular}{|c|c|c|c|c|}
\hline \multicolumn{2}{|c|}{$\begin{array}{l}\text { Temperature } 0.0^{\circ} \mathrm{C} \\
\text { Sat. Pressure: } 41.98 \text { psia }\end{array}$} & & & \\
\hline Density & Pressure & $\begin{array}{l}\% \text { Refrig. } \\
\text { Conc. }\end{array}$ & $\begin{array}{l}\text { Viscosity } \\
\text { cP }\end{array}$ & $\begin{array}{c}\text { Viscosity } \\
\text { cSt }\end{array}$ \\
\hline 0.9325 & 15.00 & none & 100.42 & 107.69 \\
\hline 0.9568 & 26.00 & 17.81 & 37.17 & 38.85 \\
\hline 0.9753 & 35.75 & 27.49 & 19.17 & 19.66 \\
\hline 1.0388 & 42.00 & 46.15 & 4.27 & 4.11 \\
\hline
\end{tabular}

\begin{tabular}{|c|c|c|c|c|}
\hline \multicolumn{2}{|c|}{$\begin{array}{l}\text { Temperature: } 80^{\circ} \mathrm{C} \\
\text { Sat. Pressure } 382.61 \text { psia }\end{array}$} & \multirow[b]{2}{*}{$\begin{array}{l}\% \text { Refrig. } \\
\text { Conc. }\end{array}$} & \multirow[b]{2}{*}{$\begin{array}{c}\text { Viscosity } \\
\text { cP }\end{array}$} & \multirow[b]{2}{*}{$\begin{array}{l}\text { Viscosity } \\
\text { cSt }\end{array}$} \\
\hline Density & Pressure & & & \\
\hline 0.8605 & 40.50 & 5.20 & 6.78 & 7.88 \\
\hline 0.8683 & 101.00 & 9.28 & 5.06 & 5.83 \\
\hline 0.8811 & 217.50 & 20.64 & 2.96 & 3.32 \\
\hline 0.8911 & 217.50 & 21.74 & 2.96 & 3.32 \\
\hline 0.9125 & 311.00 & 32.32 & 1.71 & 1.88 \\
\hline 0.9404 & 373.00 & 58.41 & 0.76 & 0.81 \\
\hline 0.9404 & 373.00 & 57.70 & 0.76 & 0.81 \\
\hline
\end{tabular}

\begin{tabular}{|c|c|c|c|c|}
\hline \multicolumn{2}{|c|}{$\begin{array}{l}\text { Temperature: }-15.0^{\circ} \mathrm{C} \\
\text { Sat. Pressure: } 23.51 \mathrm{psia}\end{array}$} & \multirow[b]{2}{*}{$\begin{array}{l}\% \text { Refrig. } \\
\text { Conc. }\end{array}$} & \multirow[b]{2}{*}{$\begin{array}{c}\text { Viscosity } \\
c P\end{array}$} & \multirow[b]{2}{*}{$\begin{array}{l}\text { Viscosity } \\
\text { cSt }\end{array}$} \\
\hline Density & Pressure & & & \\
\hline 0.9668 & 14.50 & 22.64 & 113.07 & 116.95 \\
\hline 0.9825 & 18.50 & 25.61 & 67.08 & 68.27 \\
\hline 1.0402 & 23.00 & 43.20 & 16.19 & 15.56 \\
\hline 1.0802 & 23.70 & 51.86 & 4.83 & 4.47 \\
\hline
\end{tabular}

\begin{tabular}{|c|c|c|c|c|}
\hline \multicolumn{2}{|c|}{$\begin{array}{l}\text { Temperature: } 60.0^{\circ} \mathrm{C} \\
\text { Sat. Pressure: } 245.24 \mathrm{psia}\end{array}$} & \multirow[b]{2}{*}{$\begin{array}{l}\text { \% Refrig. } \\
\text { Conc. }\end{array}$} & \multirow[b]{2}{*}{$\begin{array}{c}\text { Viscosity } \\
\text { cP }\end{array}$} & \multirow[b]{2}{*}{$\begin{array}{l}\text { Viscosity } \\
\text { cSt }\end{array}$} \\
\hline Density & Pressure & & & \\
\hline 0.8954 & 40.25 & 3.15 & 10.15 & 11.34 \\
\hline 0.9054 & 84.00 & 9.46 & 7.38 & 8.15 \\
\hline 0.914 & 127.50 & 15.85 & 5.04 & 5.51 \\
\hline 0.9287 & 182.50 & 25.21 & 2.98 & 3.20 \\
\hline 0.9546 & 235.00 & 49.51 & 1.09 & 1.14 \\
\hline 0.9725 & 235.00 & 49.33 & 1.07 & 1.10 \\
\hline
\end{tabular}

\begin{tabular}{|c|c|c|c|c|}
\hline \multicolumn{2}{|c|}{$\begin{array}{l}\text { Temperature: }-30^{\circ} \mathrm{C} \\
\text { Sat. Pressure: } 12.20 \mathrm{psia}\end{array}$} & & & \\
\hline Density & Pressire & $\begin{array}{l}\text { \% Refrig. } \\
\text { Conc. }\end{array}$ & $\begin{array}{c}\text { Viscosity } \\
c P\end{array}$ & $\begin{array}{l}\text { Viscosity } \\
\text { cSt }\end{array}$ \\
\hline 1.0053 & 7.50 & 32.33 & 98.36 & 97.84 \\
\hline 1.1779 & 12.50 & 58.15 & 6.83 & 5.80 \\
\hline
\end{tabular}

\begin{tabular}{|c|c|c|c|c|}
\hline \multicolumn{2}{|c|}{$\begin{array}{l}\text { Temperature: } 40.0^{\circ} \mathrm{C} \\
\text { Sat. Pressure: } 147.47 \mathrm{psia}\end{array}$} & \multirow[b]{2}{*}{$\begin{array}{l}\text { \%Refrig. } \\
\text { Conc. }\end{array}$} & \multirow[b]{2}{*}{$\begin{array}{c}\text { Viscosity } \\
\text { cP }\end{array}$} & \multirow[b]{2}{*}{$\begin{array}{l}\text { Viscosity } \\
\text { cSt }\end{array}$} \\
\hline Density & Pressure & & & \\
\hline 0.8168 & 43.50 & 6.89 & 17.06 & 18.61 \\
\hline 0.9368 & 85.50 & 19.60 & 12.78 & $13 . \overline{64}$ \\
\hline 0.9382 & 107.50 & 24.69 & 5.47 & 5.83 \\
\hline 0.9775 & 127.50 & 38.00 & 2.53 & 2.59 \\
\hline 1.0081 & 142.00 & 52.76 & 1.31 & 1.30 \\
\hline 0.9268 & 142.00 & 52.66 & 1.42 & 1.54 \\
\hline
\end{tabular}


APPENDIX E:

Viscosity, Density and Gas Solubility of 32 ISO VG Branched Acid Polyolester at Various Temperatures with HFC-134a 
32 ISO VG Branched Acid Polyolester With HFC-134a at $125^{\circ} \mathrm{C}$

Figure E.1

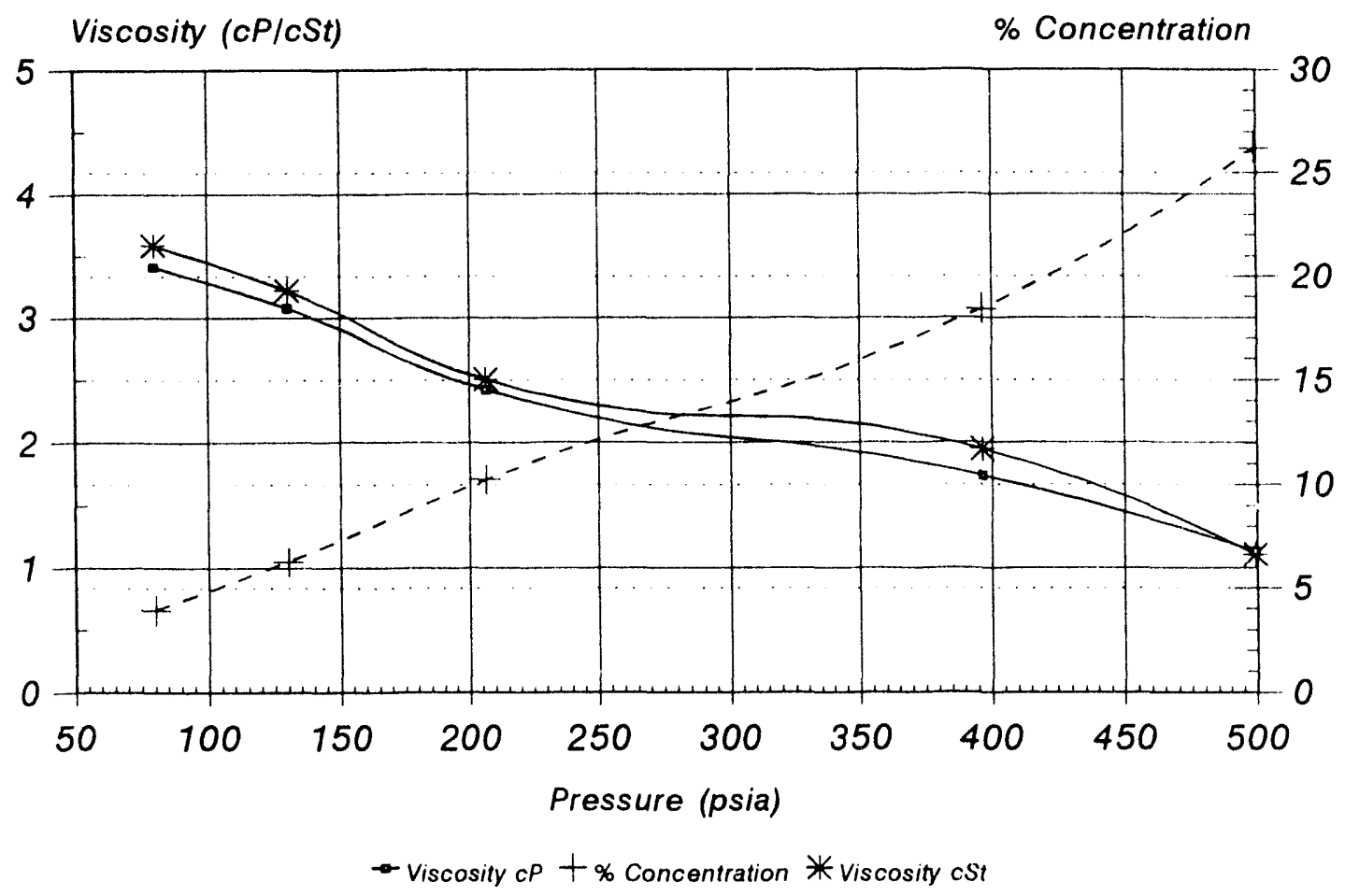

Viscosity via Gas Solubility Equilibrium

Oil degassed to 20 Millitorr

\section{Viscosity and Gas Solubility}

32 ISO VG Branched Acid Polyolester with HFC-134a at $80^{\circ} \mathrm{C}$

Figure E.2

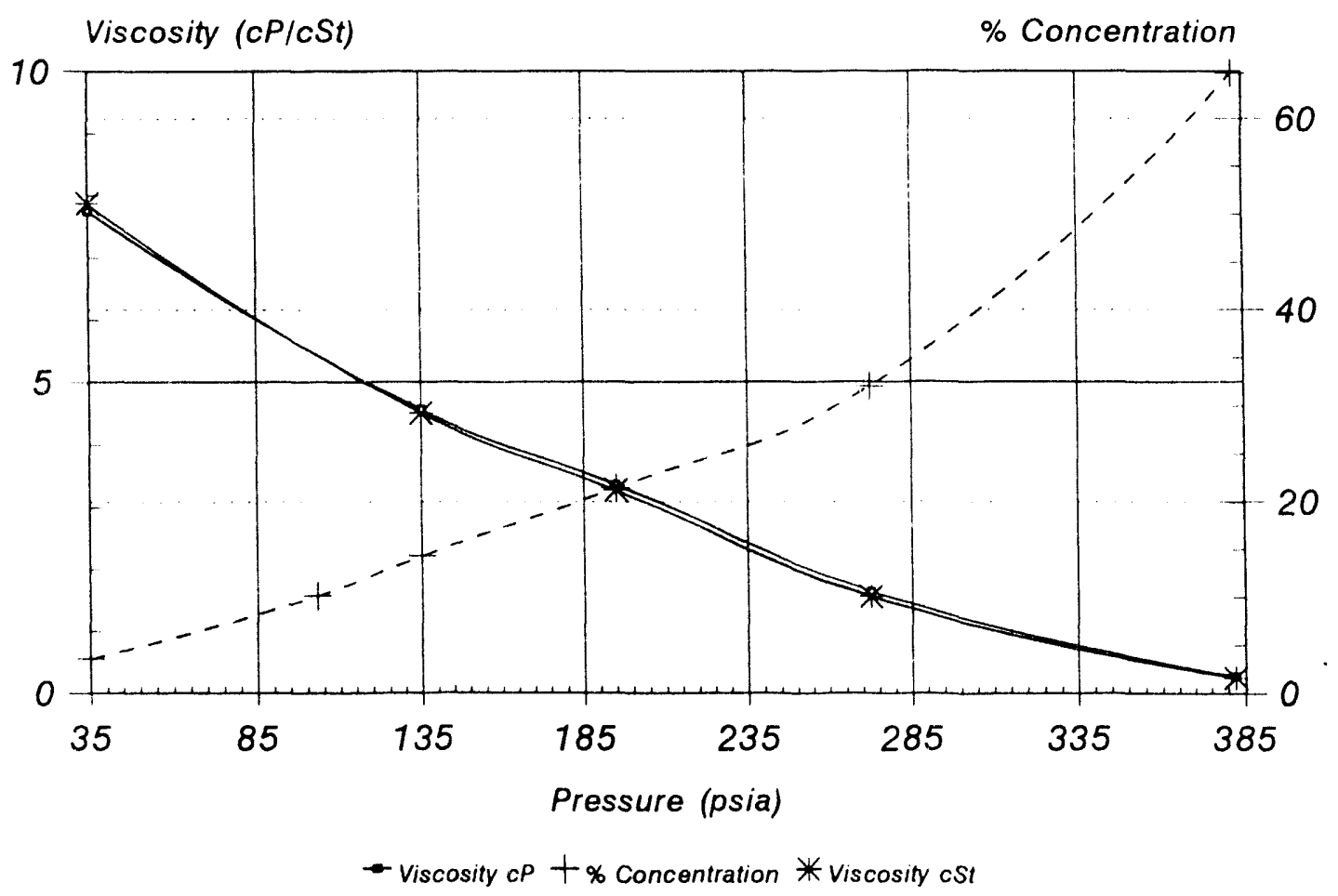




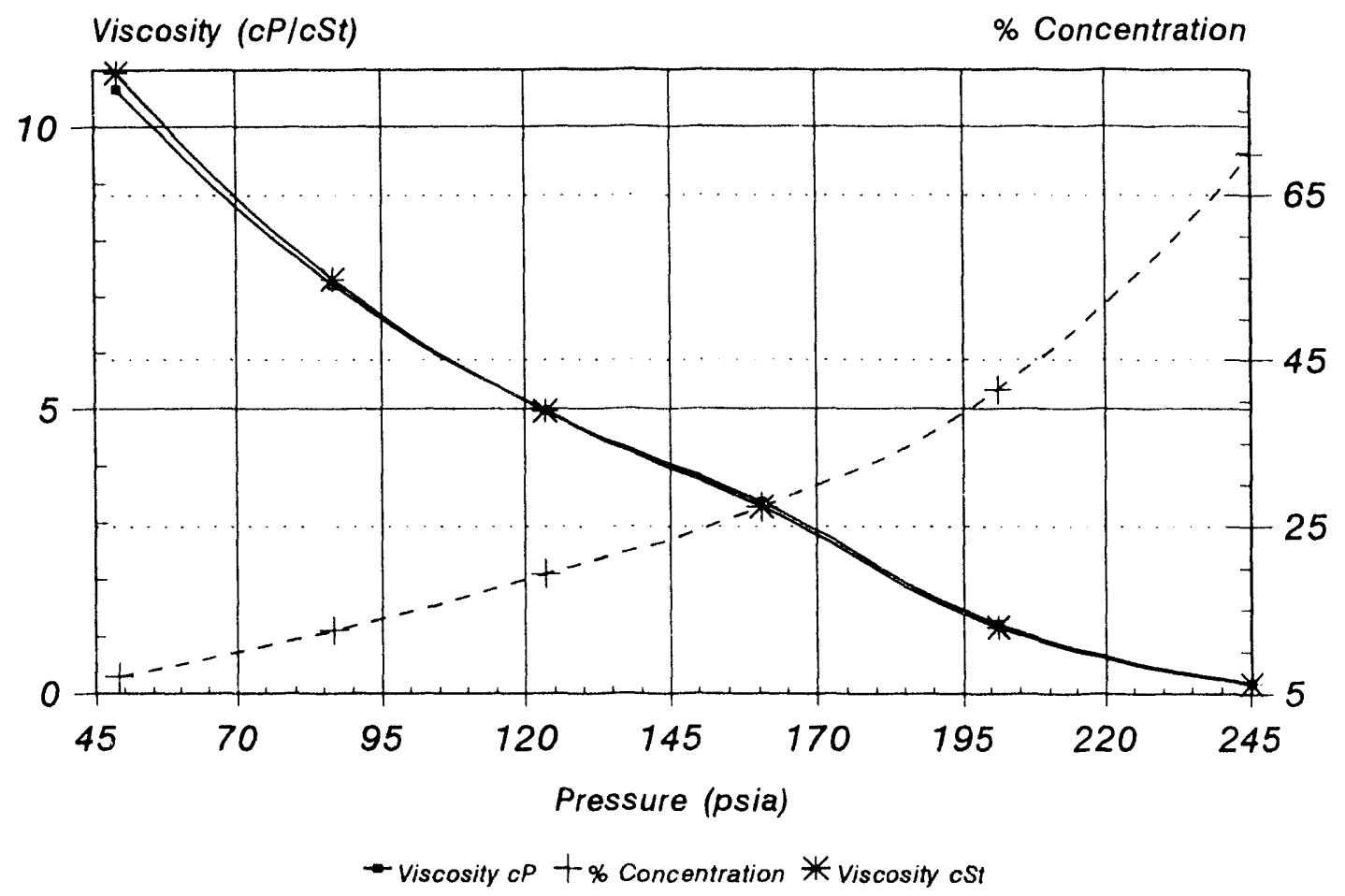

Viscosity via Gas Solubility Equilibrium Oil degassed to 20 Millitorr

Viscosity and Gas Solubility

32 ISO VG Branched Acid Polyolester with HFC-134a at $40^{\circ} \mathrm{C}$

Figure E.4

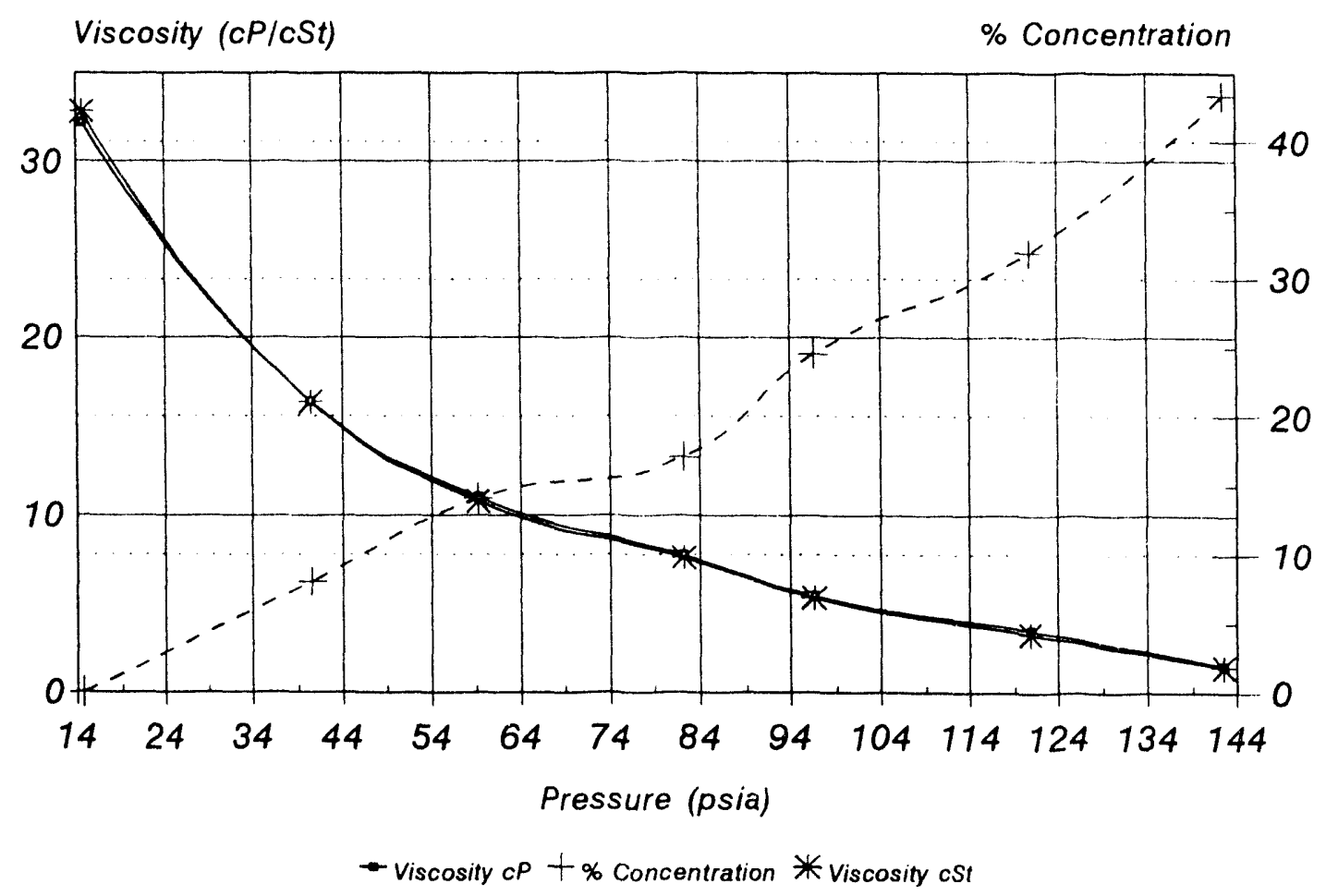




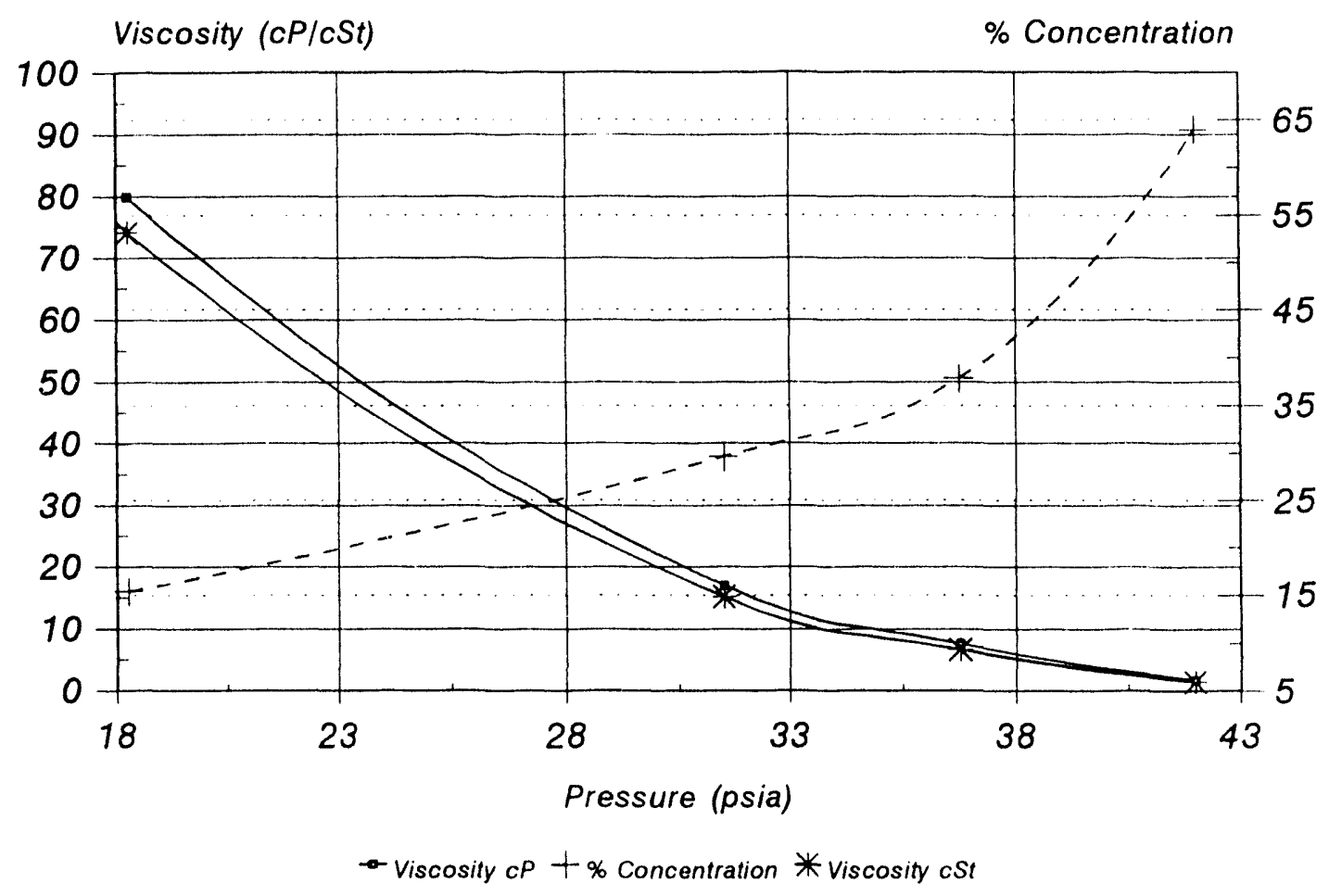

Viscosity via Gas Solubility Equilibrium

Oil degassed to 20 Millitorr 


\section{Raw Data: Viscosity, Density, and Solubility 32 ISO VG Branched Acid Polyolester with HFC-134a Table E.1}

\begin{tabular}{|c|c|c|c|c|}
\hline \multicolumn{5}{|c|}{$\begin{array}{ll}125^{\circ} \mathrm{C} & \text { Temperature } \\
500.0 \text { peia } & \text { Saturation Pressure }\end{array}$} \\
\hline Density & Preasure & $\begin{array}{l}\text { \% Refrig. } \\
\text { Conc. }\end{array}$ & $\begin{array}{l}\text { Viscosity } \\
\text { CP }\end{array}$ & $\begin{array}{l}\text { Viscosity } \\
\text { cSt }\end{array}$ \\
\hline 0.051 & 80.00 & 3.05 & 3.41 & 3.58 \\
\hline 0.056 & 130.00 & 6.30 & 3.08 & 3.22 \\
\hline 0.907 & 206.50 & 10.27 & 2.42 & 2.50 \\
\hline 1.003 & 396.50 & 18.42 & 1.74 & 1.95 \\
\hline 1.022 & 400.25 & 26.10 & 1.13 & 1.11 \\
\hline
\end{tabular}

\begin{tabular}{|l|r|r|r|r|}
\hline $\begin{array}{l}40^{\circ} \mathrm{C} \\
147.673 \text { psia Saturation Pressure }\end{array}$ & \multicolumn{2}{|c|}{} \\
\hline Density & Pressure & $\begin{array}{r}\text { \% Refrig. } \\
\text { Conc. }\end{array}$ & $\begin{array}{r}\text { Viscosity } \\
\text { cP }\end{array}$ & $\begin{array}{c}\text { Viscosity } \\
\text { cSt }\end{array}$ \\
\hline 1.000 & 40.50 & 8.00 & 16.40 & 16.41 \\
\hline 1.013 & 59.25 & 14.08 & 10.88 & 10.74 \\
\hline 1.025 & 82.25 & $\begin{array}{r}17.08 \\
\text { (not plotted) }\end{array}$ & 7.56 & 7.37 \\
\hline 1.035 & 96.50 & 24.54 & 5.20 & 5.22 \\
\hline 1.058 & 120.78 & 31.92 & 3.20 & 3.11 \\
\hline 1.066 & 142.50 & 43.30 & 1.47 & 1.38 \\
\hline
\end{tabular}

\begin{tabular}{|c|c|c|c|c|}
\hline \multirow{2}{*}{\begin{tabular}{|l|}
$80^{\circ} \mathrm{C}$ \\
382 psia \\
Density
\end{tabular}} & \multicolumn{2}{|c|}{$\begin{array}{l}\text { Temperature } \\
\text { Saturation Preasure }\end{array}$} & \multirow[b]{2}{*}{$\begin{array}{c}\text { Viscosity } \\
\text { CP }\end{array}$} & \multirow[b]{2}{*}{$\begin{array}{c}\text { Viscosity } \\
\text { cSt }\end{array}$} \\
\hline & Prossure & $\begin{array}{l}\text { \% Rofrig. } \\
\text { Conc. }\end{array}$ & & \\
\hline 0.085 & 35.00 & 3.50 & 7.75 & 7.86 \\
\hline 1.000 & 103.00 & 10.14 & 5.10 & 4.77 \\
\hline 1.013 & 135.00 & 14.35 & 4.56 & 4.50 \\
\hline 1.020 & 105.00 & 21.40 & 3.36 & 3.27 \\
\hline 1.054 & 272.50 & 32.07 & 1.64 & .1 .55 \\
\hline 1.086 & 382.00 & 64.83 & 0.28 & 0.25 \\
\hline
\end{tabular}

\begin{tabular}{|c|c|c|c|c|}
\hline $\begin{array}{l}0^{\circ} \mathrm{C} \\
41.98 \text { paia }\end{array}$ & $\begin{array}{l}\text { Temperatur } \\
\text { Seturation P }\end{array}$ & essure & & \\
\hline Density & Pressure & $\begin{array}{l}\text { \% Rofrig. } \\
\text { Conc. }\end{array}$ & $\begin{array}{c}\text { Viscosity } \\
\text { cP }\end{array}$ & $\begin{array}{c}\text { Viscosity } \\
\text { cSt }\end{array}$ \\
\hline 1.079 & 18.25 & 15.38 & 78.83 & 73.90 \\
\hline 1.122 & 31.50 & 29.65 & 16.93 & 15.08 \\
\hline 1.145 & 36.75 & 37.85 & 7.60 & 6.63 \\
\hline 1.206 & 41.98 & 63.96 & 1.70 & 1.41 \\
\hline
\end{tabular}

\begin{tabular}{|c|c|c|c|c|}
\hline \multicolumn{3}{|c|}{$\begin{array}{ll}60^{\circ} \mathrm{C} & \text { Temperature } \\
245.2 \text { psia } & \text { Saturation Pressure }\end{array}$} & \multirow[b]{2}{*}{$\begin{array}{c}\text { Viscosity } \\
\text { cP }\end{array}$} & \multirow[b]{2}{*}{$\begin{array}{l}\text { Viscosity } \\
\text { cSt }\end{array}$} \\
\hline Density & Pressure & $\begin{array}{l}\text { \% Rofrig. } \\
\text { Conc. }\end{array}$ & & \\
\hline 0.073 & 40.00 & 7.01 & 10.66 & 10.95 \\
\hline 0.086 & 86.75 & 12.51 & 7.21 & 7.31 \\
\hline 1.004 & 123.50 & 19.30 & 4.98 & 4.06 \\
\hline 1.025 & 160.50 & 27.35 & 3.36 & 3.28 \\
\hline 1.050 & 201.25 & 41.45 & 1.22 & 1.10 \\
\hline 1.088 & 245.20 & 69.78 & 0.19 & 0.18 \\
\hline
\end{tabular}




\section{APPENDIX F:}

Viscosity, Density and Gas Solubility of 32 ISO VG Branched Acid Polyolester at Various Temperatures with HFC-143a 


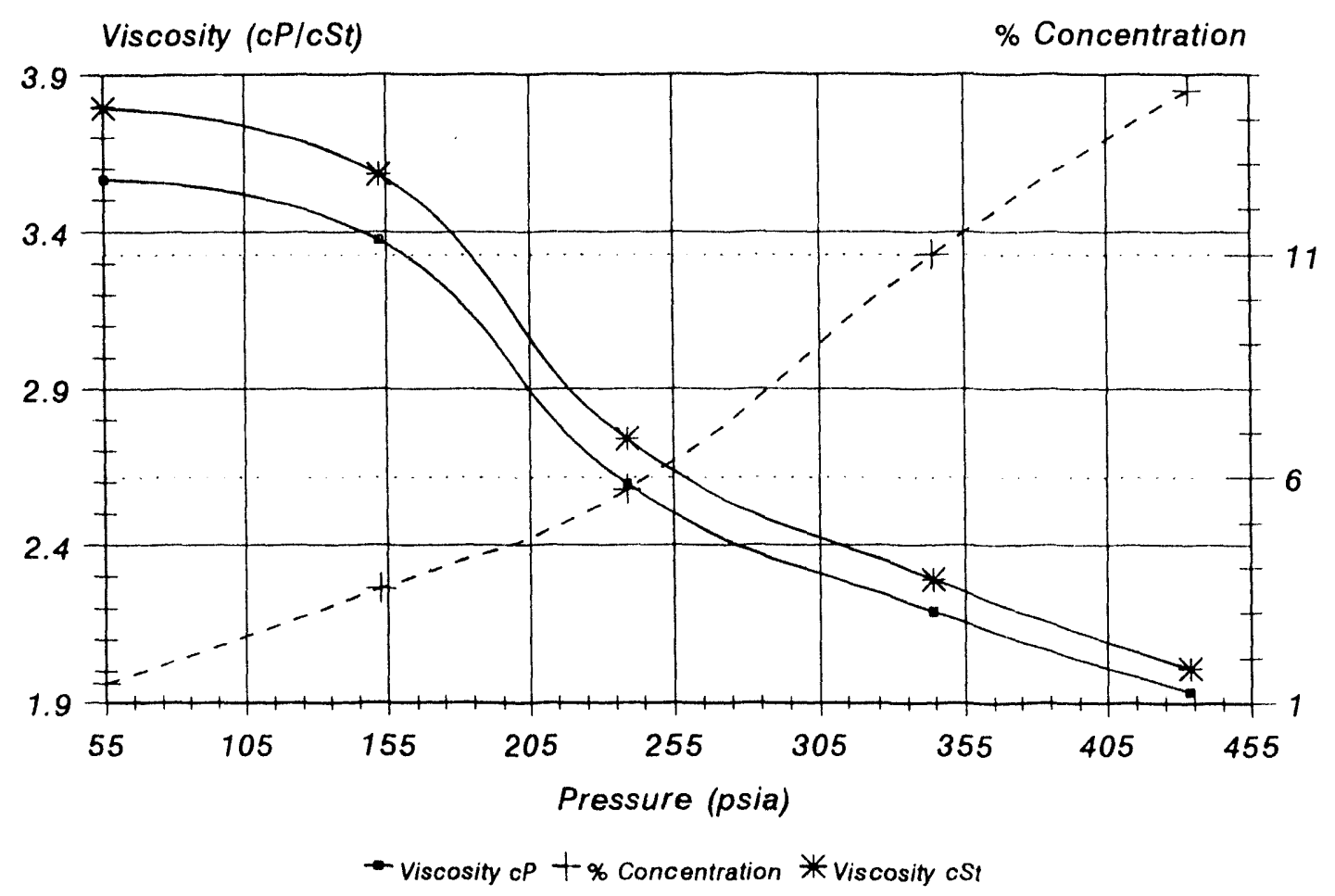

Viscosity via Gas Solubility Equilibrium

Oil degassed to 20 Millitorr

Viscosity and Gas Solubility

32 ISO VG Branched Acid Polyolester with HFC-143a at $80^{\circ} \mathrm{C}$

Figure F.2

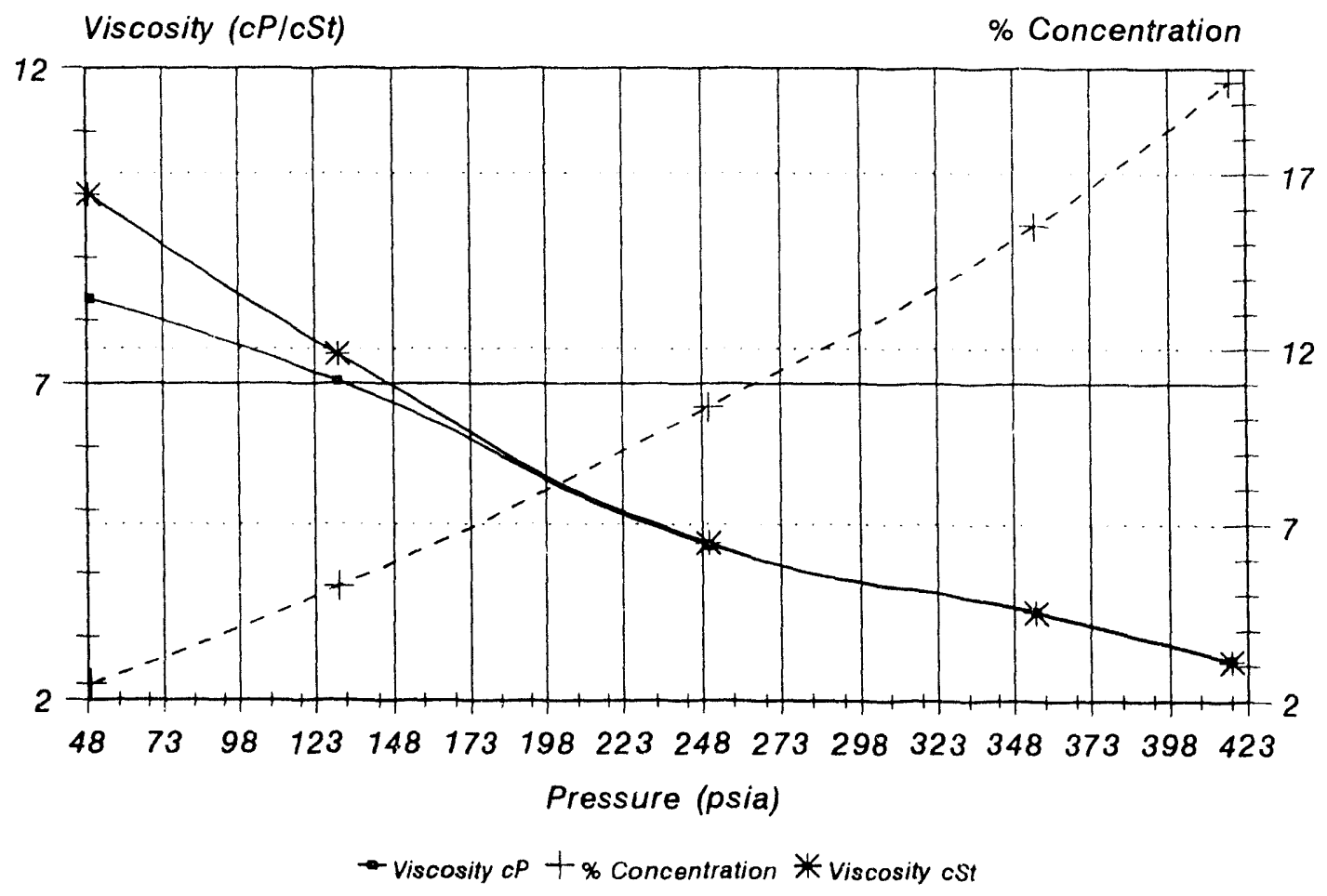




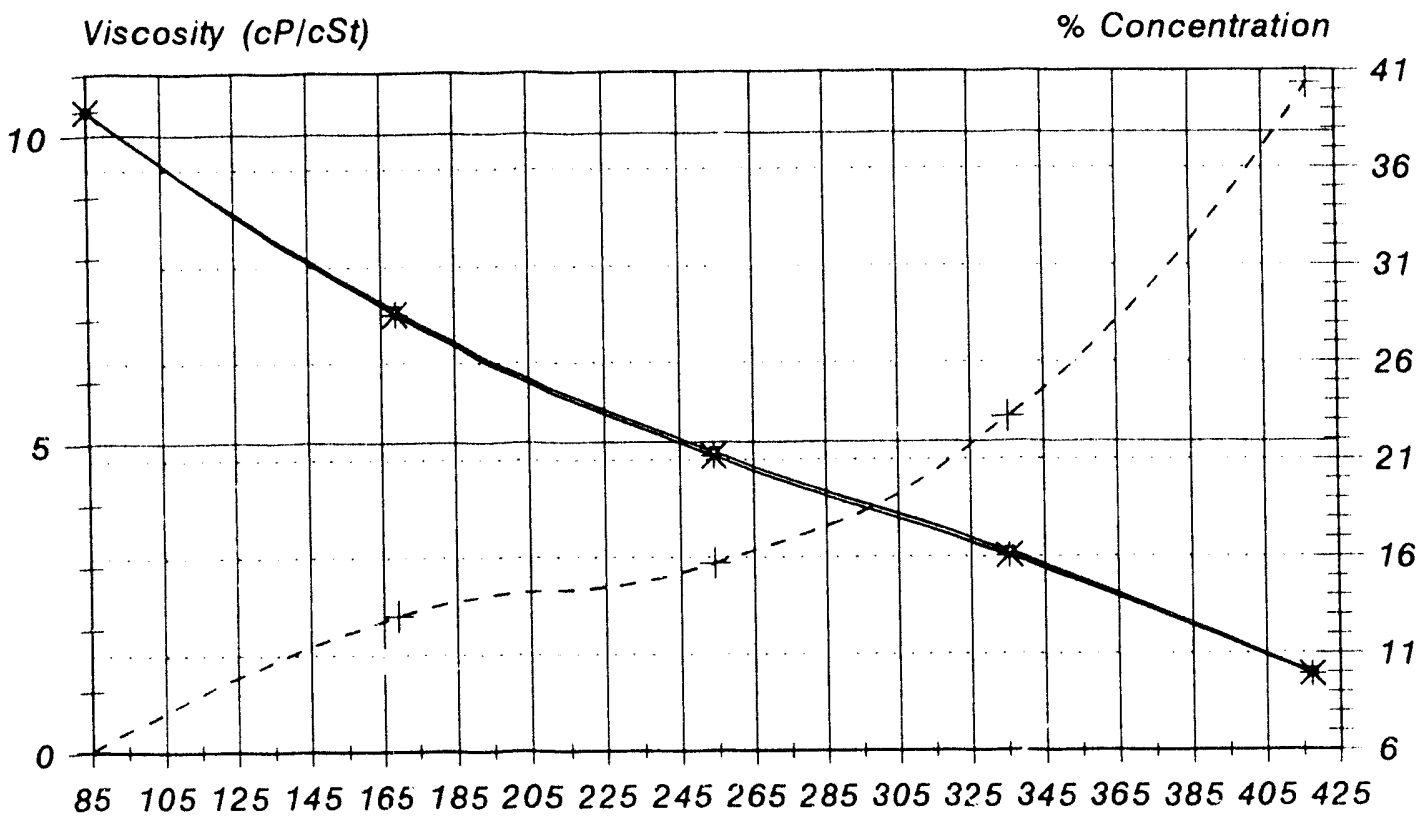

Pressure (psia)

- Viscosity cP $+\%$ Concentration $*$ Viscosity cSt

Viscosity via Gas Solubility Equilibrium

Oil degassed to 20 Millitorr

\section{Viscosity and Gas Solubility}

32 ISO Branched Acid Polyolester with HFC-143a at $40^{\circ} \mathrm{C}$

Figure F.4

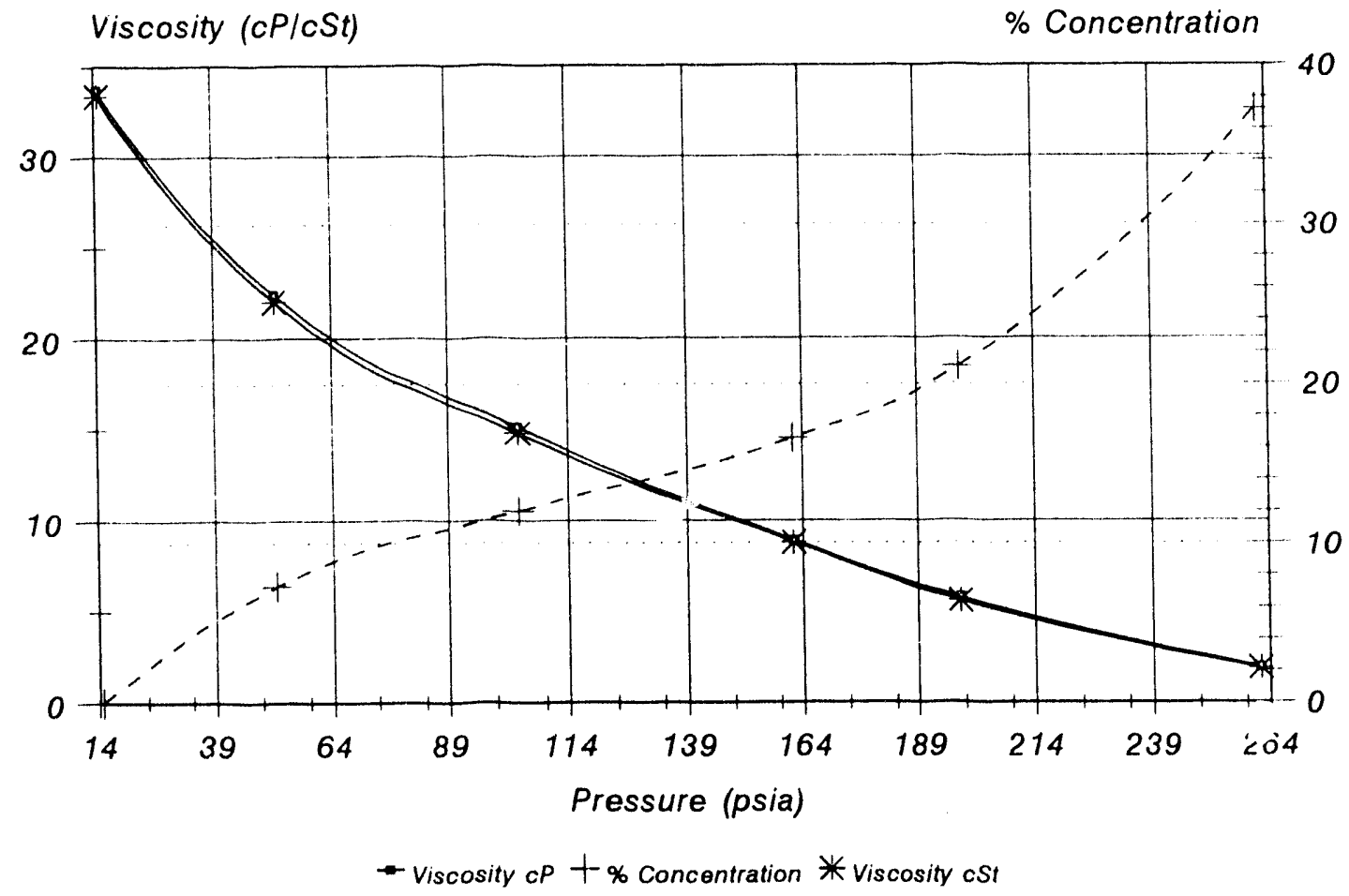




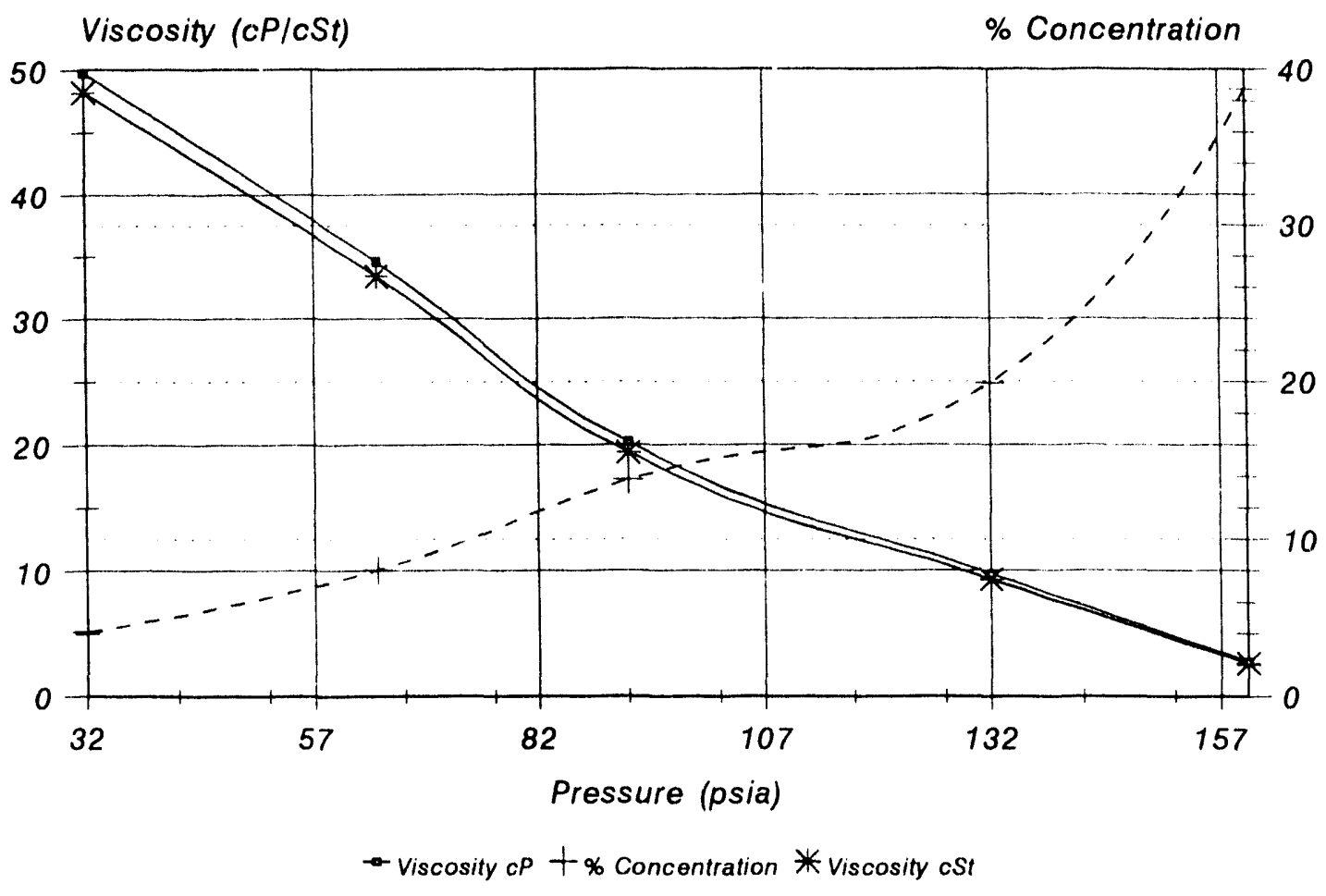

Viscosity via Gas Solubility Equilibrium Oil degassed to 20 Millitorr

Viscosity and Gas Solubility 32 ISO VG Branched Acid Polyolester with HFC-143a at $0^{\circ} \mathrm{C}$ Figure F.6

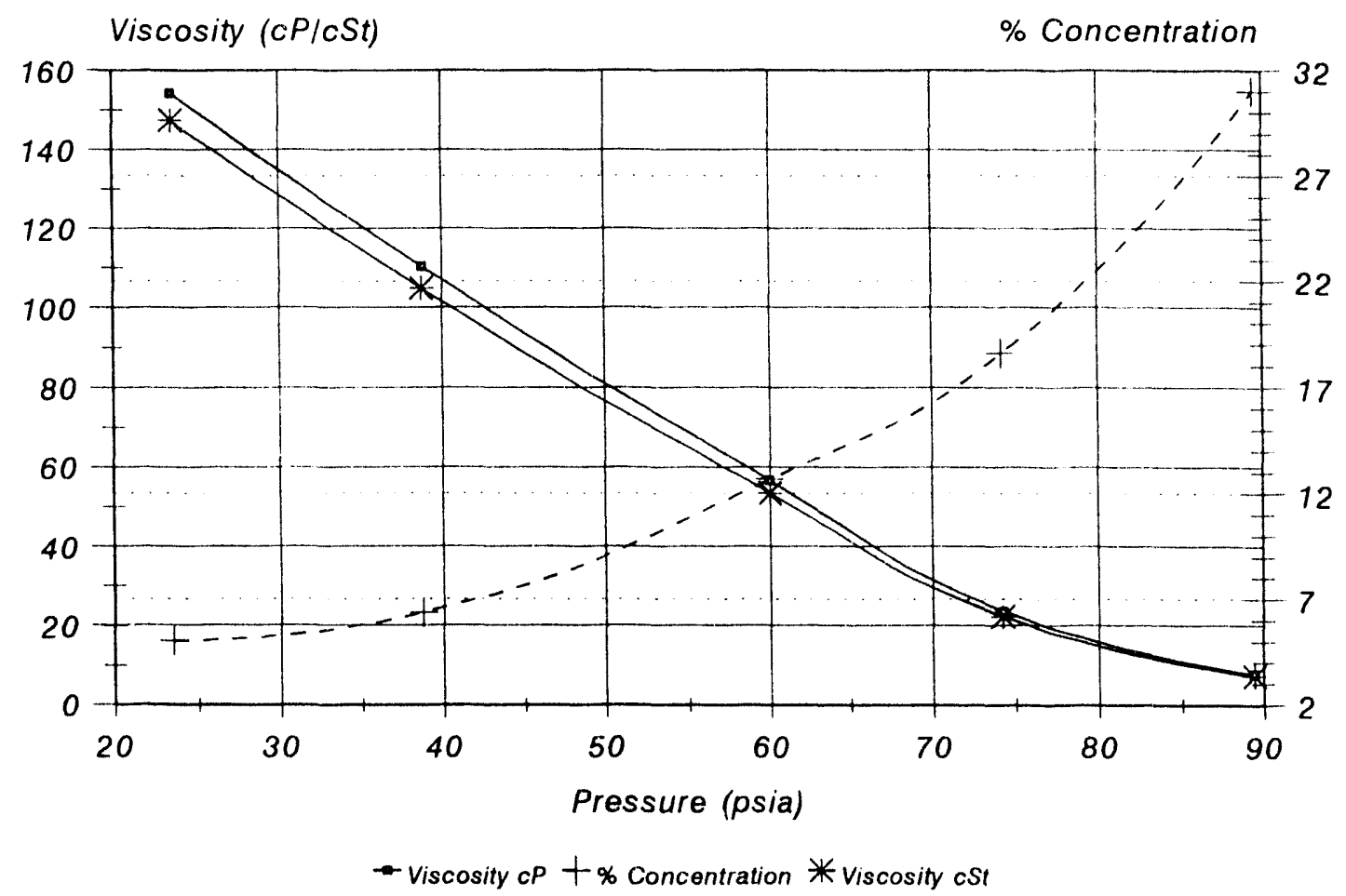




\section{Raw Data: Viscosity, Density, and Solubility 32 ISO Branched Acid Polyolester with HFC-143a \\ Table F.1}

\begin{tabular}{|c|c|c|c|c|}
\hline \multicolumn{3}{|c|}{$\begin{array}{l}125.0^{\circ} \mathrm{C} \quad \text { Temperature } \\
>500.0 \text { paia Saturation Pressure }\end{array}$} & \multirow[b]{2}{*}{$\begin{array}{c}\text { Viscosity } \\
\text { cP }\end{array}$} & \multirow[b]{2}{*}{$\begin{array}{l}\text { Viscosity } \\
\text { cSt }\end{array}$} \\
\hline Density & Preseure & $\begin{array}{l}\text { \% Rofrig. } \\
\text { Conc. }\end{array}$ & & \\
\hline 0.930 & 58.00 & 1.41 & 3.56 & 3.78 \\
\hline 0.042 & 152.50 & 3.54 & 3.38 & 3.58 \\
\hline 0.048 & 230.00 & 5.74 & 2.60 & 2.74 \\
\hline 0.050 & 344.00 & 11.01 & 2.10 & 2.28 \\
\hline 0.063 & 433.50 & 14.04 & 1.04 & 2.01 \\
\hline
\end{tabular}

\begin{tabular}{|c|c|c|c|c|}
\hline \multicolumn{3}{|c|}{$\begin{array}{ll}40^{\circ} \mathrm{C} & \text { Temperature } \\
268.60 \text { psia } & \text { Saturation Pressure }\end{array}$} & \multirow[b]{2}{*}{$\begin{array}{c}\text { Viacosity } \\
\text { cP }\end{array}$} & \multirow[b]{2}{*}{$\begin{array}{c}\text { Viscosity } \\
\text { cSt }\end{array}$} \\
\hline Density & Pressure & $\begin{array}{l}\text { \% Refilg. } \\
\text { Conc. }\end{array}$ & & \\
\hline 1.010 & 14.70 & 0.00 & 33.71 & 33.38 \\
\hline 1.017 & 52.00 & 7.32 & 22.30 & 22.01 \\
\hline 1.023 & 103.50 & 12.01 & 15.12 & 14.78 \\
\hline 1.020 & 102.00 & 10.60 & 8.90 & 8.04 \\
\hline 1.033 & 198.00 & 21.07 & 5.77 & 5.58 \\
\hline 1.033 & 202.00 & 37.25 & 1.94 & 1.88 \\
\hline
\end{tabular}

\begin{tabular}{|c|c|c|c|c|}
\hline $\begin{array}{l}80^{\circ} \mathrm{C} \\
>500 \text { paia }\end{array}$ & $\begin{array}{l}\text { Tomperatur } \\
\text { Saturation } P\end{array}$ & ressure & & \\
\hline Density & Preasure & $\begin{array}{l}\text { \% Rofrig. } \\
\text { Conc. }\end{array}$ & $\begin{array}{c}\text { Viscosity } \\
\text { cP }\end{array}$ & $\begin{array}{c}\text { Viscosity } \\
\text { cst }\end{array}$ \\
\hline 0.835 & 40.00 & 2.41 & 8.35 & 10.00 \\
\hline 0.944 & 130.50 & 5.23 & 7.08 & 7.47 \\
\hline 0.092 & 250.00 & 10.33 & 4.45 & 4.48 \\
\hline 1.004 & 355.00 & 15.51 & 3.40 & 3.30 \\
\hline 1.008 & 418.00 & 10.63 & 2.04 & 2.02 \\
\hline
\end{tabular}

\begin{tabular}{|c|c|c|c|c|}
\hline \multicolumn{3}{|c|}{$\begin{array}{ll}20^{\circ} \mathrm{C} & \text { Temperature } \\
160.30 \text { psia } & \text { Saturation Pressure }\end{array}$} & \multirow[b]{2}{*}{$\begin{array}{c}\text { Viscosity } \\
\text { CP }\end{array}$} & \multirow[b]{2}{*}{$\begin{array}{c}\text { Viscosity } \\
\text { cst }\end{array}$} \\
\hline Density & Pressure & $\begin{array}{l}\text { \% Retrig. } \\
\text { Conc. }\end{array}$ & & \\
\hline 1.032 & 32.00 & 4.11 & 49.73 & 48.10 \\
\hline 1.035 & 04.00 & 8.07 & 34.59 & 33.43 \\
\hline 1.042 & 92.00 & 13.70 & 20.20 & 19.38 \\
\hline 1.048 & 132.00 & 10.88 & 9.72 & 0.28 \\
\hline 1.054 & 160.00 & 38.75 & 2.73 & 2.59 \\
\hline
\end{tabular}

\begin{tabular}{|c|c|c|c|c|}
\hline \multicolumn{3}{|c|}{$\begin{array}{ll}60^{\circ} \mathrm{C} & \text { Temperature } \\
417.37 \text { psia } & \text { Saturation Pressure }\end{array}$} & \multirow[b]{2}{*}{$\begin{array}{c}\text { Viscosity } \\
\text { cP }\end{array}$} & \multirow[b]{2}{*}{$\begin{array}{c}\text { Viscosity } \\
\text { cSt }\end{array}$} \\
\hline Density & Prossure & $\begin{array}{l}\text { \% Rotrig. } \\
\text { Conc. }\end{array}$ & & \\
\hline 1.000 & 85.00 & 6.09 & 10.40 & 10.40 \\
\hline 1.008 & 169.00 & 13.02 & 7.14 & 7.08 \\
\hline 1.014 & 254.25 & 15.68 & 4.85 & 4.78 \\
\hline 1.022 & 335.50 & 23.16 & 3.22 & 3.15 \\
\hline 1.022 & 417.37 & 40.34 & 1.20 & 1.23 \\
\hline
\end{tabular}

\begin{tabular}{|l|r|r|r|r|}
\hline $\begin{array}{l}0^{\circ} \mathrm{C} \\
89.43 \text { psia }\end{array}$ & \multicolumn{3}{|c|}{$\begin{array}{l}\text { Temperature } \\
\text { Saturation Pressure }\end{array}$} \\
\hline Density & Pressure & $\begin{array}{c}\text { \% Refrig. } \\
\text { Conc. }\end{array}$ & $\begin{array}{c}\text { Viscosity } \\
\text { cP }\end{array}$ & $\begin{array}{c}\text { Viscosity } \\
\text { cSt }\end{array}$ \\
\hline 1.047 & 23.50 & 5.02 & 154.26 & 147.28 \\
\hline 1.053 & 38.75 & 6.37 & 110.34 & 104.83 \\
\hline 1.061 & 60.00 & 12.08 & 56.72 & 53.44 \\
\hline 1.064 & 74.25 & 18.59 & 23.73 & 22.30 \\
\hline 1.072 & 89.43 & 31.01 & 7.82 & 7.30 \\
\hline
\end{tabular}




\section{APPENDIX G:}

Viscosity, Density and Gas Solubility of 32 ISO VG Mixed Acid Polyolester at Various Temperatures with HFC-143a 


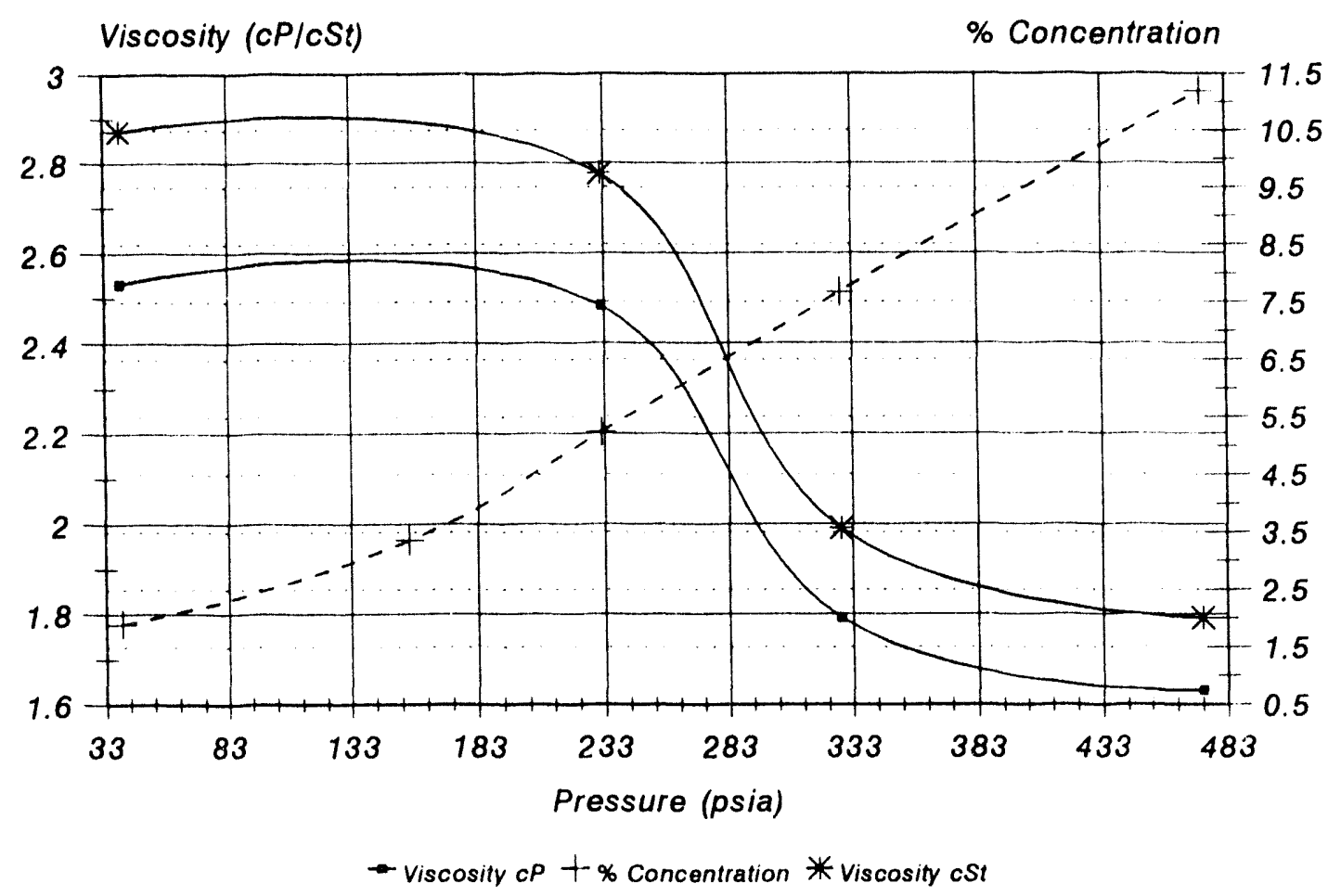

VIscosity via Gas Solubility Equilibrium

Oil degassed to 20 Millitorr

Viscosity and Gas Solubility

32 ISO VG Mixed Acid Polyolester with HFC-143a at $80^{\circ} \mathrm{C}$

Figure $\mathrm{G} .2$

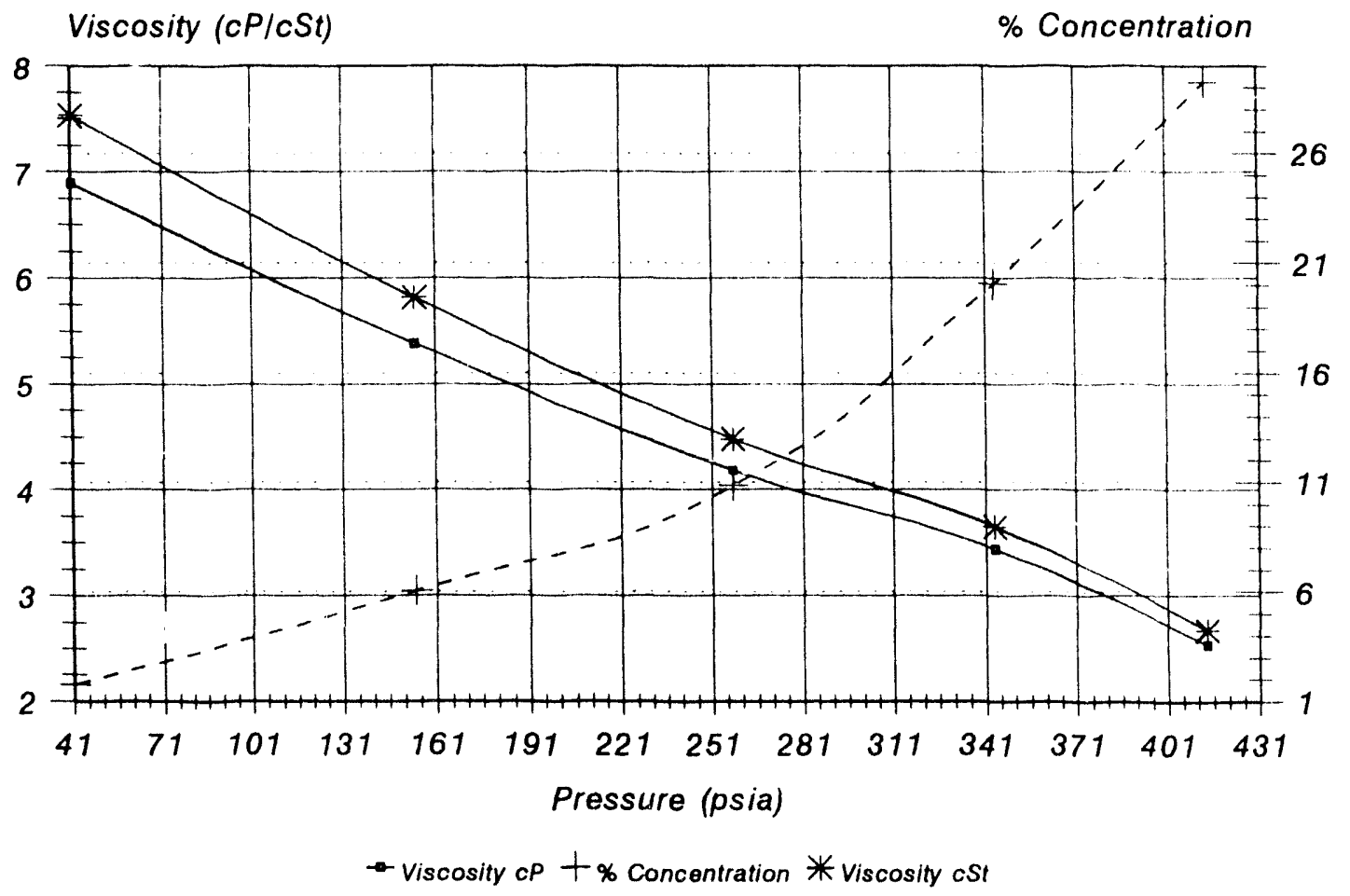




\section{Viscosity and Gas Solubility}

32 ISO VG Mixed Acid Polyolester with HFC-143a at $60^{\circ} \mathrm{C}$

Figure G.3

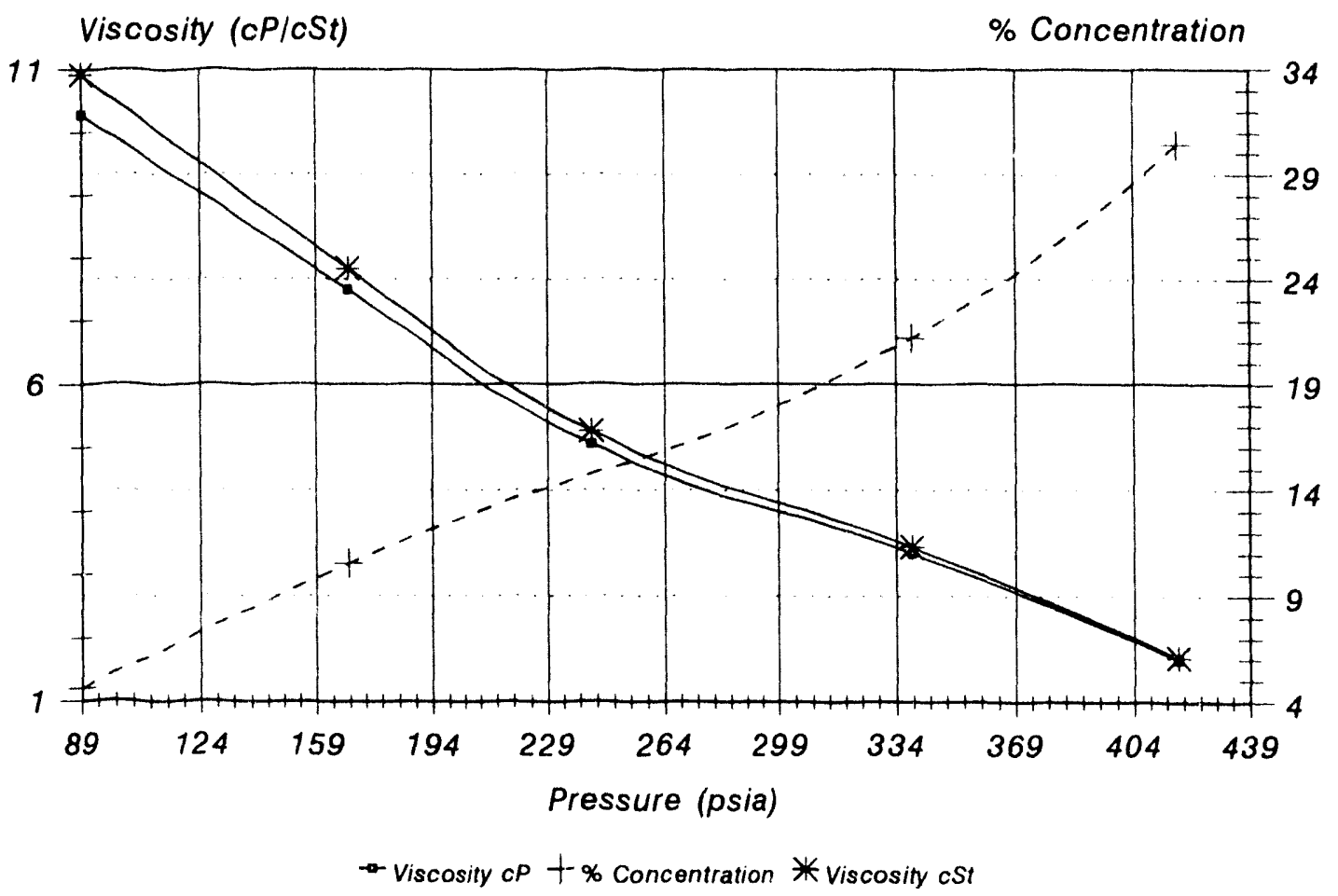

Viscosity via Gas Solubility Equilibrium

Oil degassed to 20 Millitorr

Viscosity and Gas Solubility

32 ISO VG Mixed Acid Polyolester with HFC-143a at $40^{\circ} \mathrm{C}$

Figure G.4

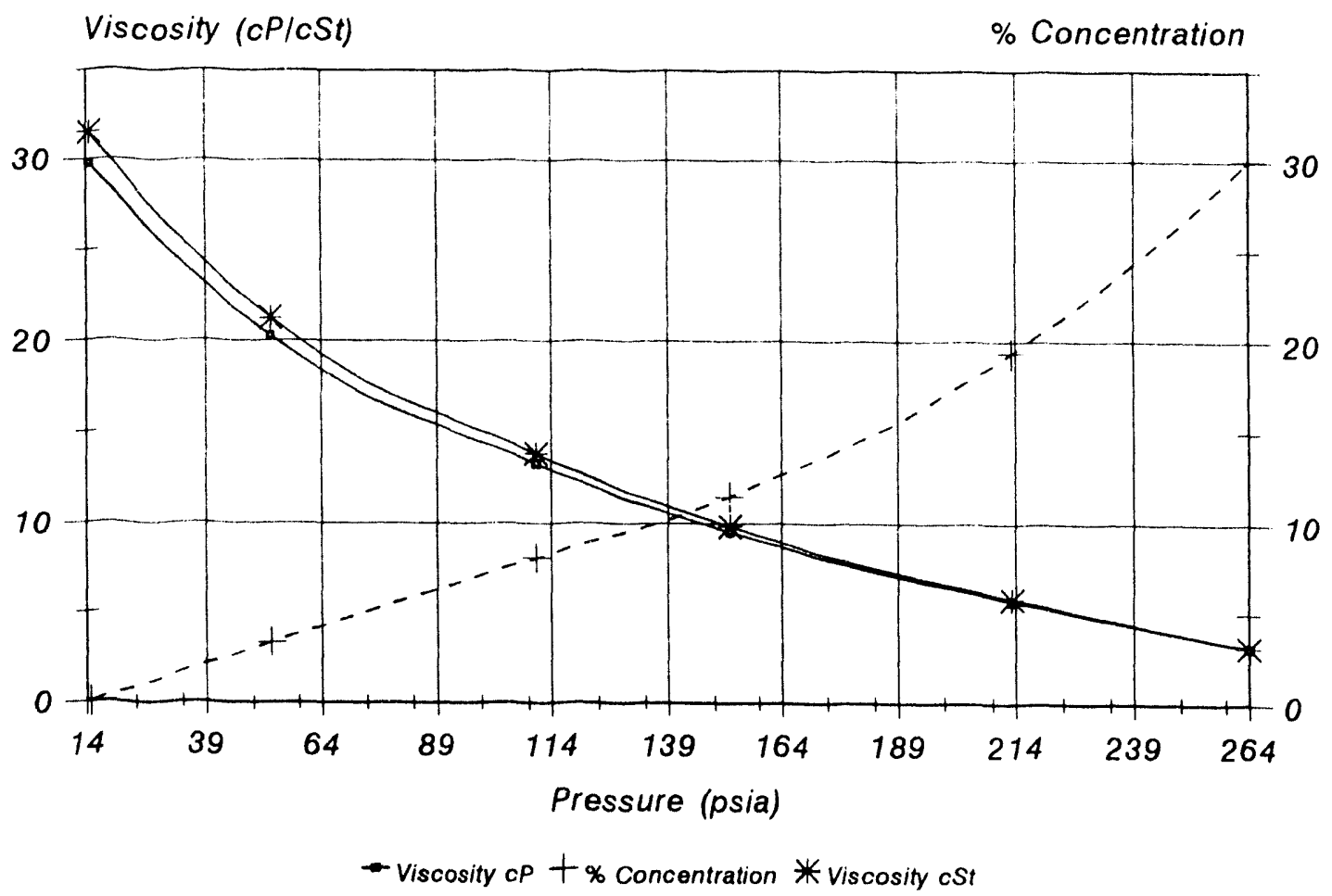


32 ISO VG Mixed Acid Polyolester with HFC-143a at $20^{\circ} \mathrm{C}$

Figure G.5

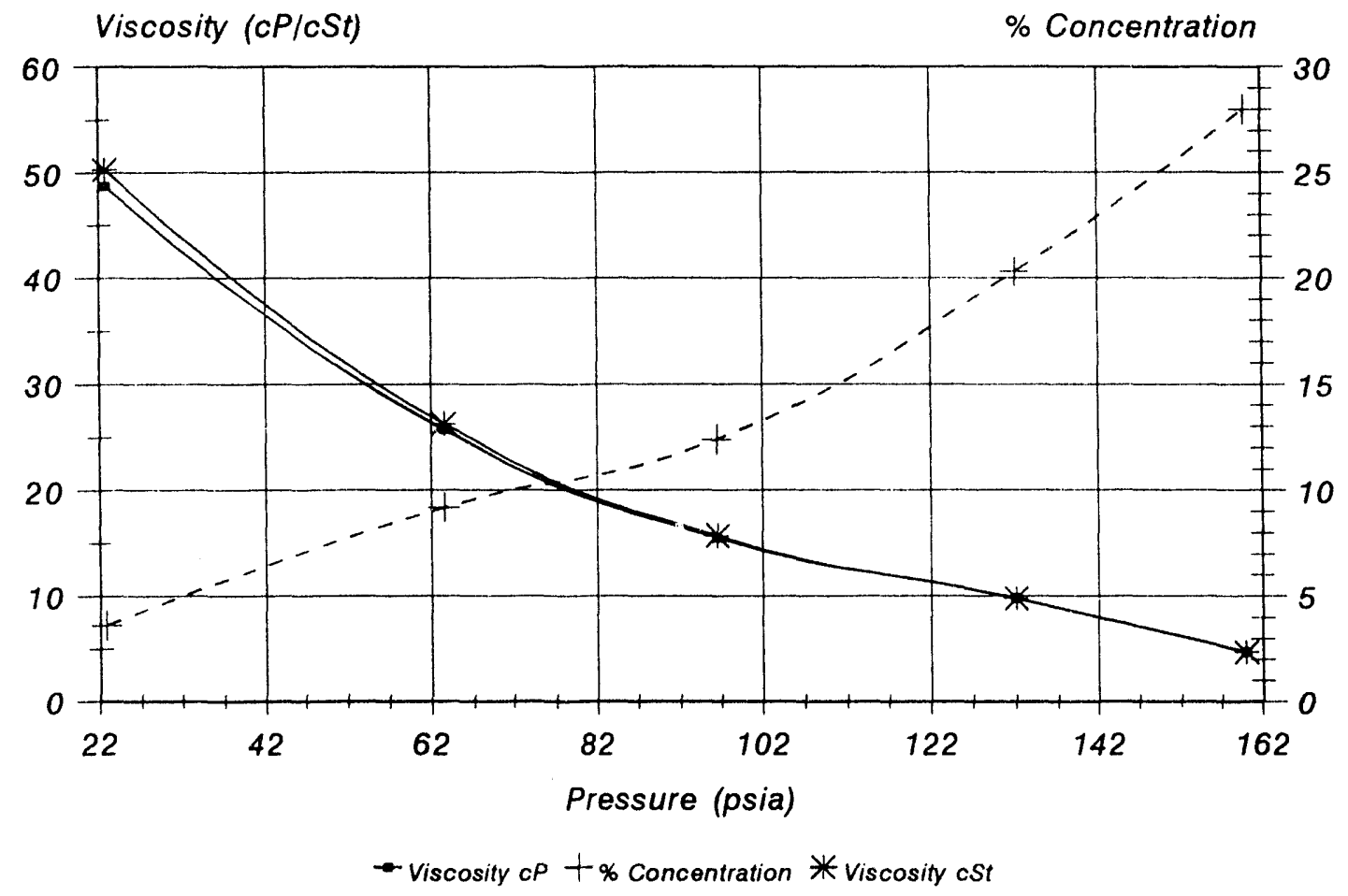

Viscosity via Gas Solubility Equilibrium

Oil degassed to 20 Millitorr

\section{Visce nd Gas Solubility \\ 32 ISO VG Mixe $\quad$ olyolester with HFC-143a at $0^{\circ} \mathrm{C}$ rigure G.6}

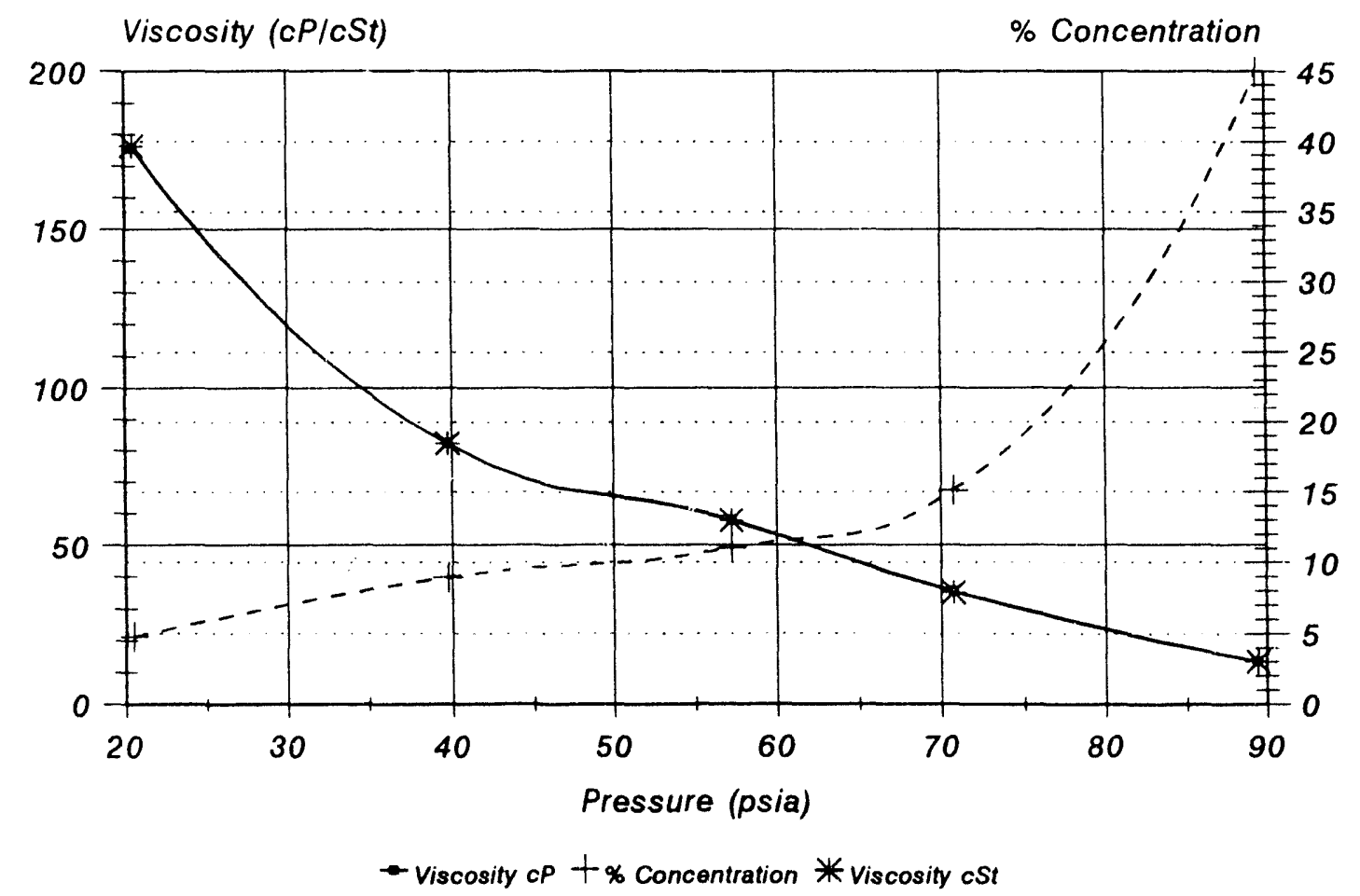




\section{Raw Data: Viscosity, Density, and Solubility 32 ISO Mixed Acid Polyolester with HFC-143a \\ Table G.1}

\begin{tabular}{|r|r|r|r|r|}
\hline $\begin{array}{l}125.0^{\circ} \mathrm{C} \\
>500.0 \text { psia Saturation Pressure }\end{array}$ & \multicolumn{3}{|c|}{} \\
\hline Density & Pressure & $\begin{array}{c}\text { \% Rofrig. } \\
\text { Conc. }\end{array}$ & $\begin{array}{c}\text { Viscosity } \\
\text { cP }\end{array}$ & $\begin{array}{c}\text { Viscosity } \\
\text { cSt }\end{array}$ \\
\hline 0.881 & 39.25 & 1.90 & 2.53 & 2.87 \\
\hline 0.889 & 156.00 & 3.36 & 2.58 & 2.91 \\
\hline 0.894 & 231.75 & 5.24 & 2.48 & 2.78 \\
\hline 0.901 & 328.00 & 7.67 & 1.79 & 1.99 \\
\hline 0.910 & 473.00 & 11.20 & 1.63 & 1.79 \\
\hline
\end{tabular}

\begin{tabular}{|c|c|c|c|c|}
\hline \multicolumn{3}{|c|}{$\begin{array}{ll}40^{\circ} \mathrm{C} & \text { Temperature } \\
266.69 \text { psia } & \text { Saturation Pressure }\end{array}$} & \multirow[b]{2}{*}{$\begin{array}{l}\text { Viscosity } \\
\text { cP }\end{array}$} & \multirow[b]{2}{*}{$\begin{array}{l}\text { Viscosity } \\
\text { cSt }\end{array}$} \\
\hline Density & Pressure & $\begin{array}{l}\text { \% Refrig. } \\
\text { Conc. }\end{array}$ & & \\
\hline 0.945 & 14.70 & 0.00 & 29.79 & 31.51 \\
\hline 0.954 & 53.00 & 3.32 & 20.28 & 21.25 \\
\hline 0.961 & 110.75 & 8.05 & 13.28 & 13.81 \\
\hline 0.969 & 152.50 & 11.49 & 9.53 & 9.84 \\
\hline 0.982 & 213.25 & 19.39 & 5.69 & 5.79 \\
\hline 0.989 & 264.00 & 30.04 & 3.11 & 3.14 \\
\hline
\end{tabular}

\begin{tabular}{|c|c|c|c|c|}
\hline $\begin{array}{l}80^{\circ} \mathrm{C} \\
>500 \text { psia }\end{array}$ & $\begin{array}{l}\text { Temperature } \\
\text { Saturation } P\end{array}$ & essure & & \\
\hline Density & Pressure & $\begin{array}{l}\text { \% Refrig. } \\
\text { Conc. }\end{array}$ & $\begin{array}{c}\text { Viscosity } \\
\text { cP }\end{array}$ & $\begin{array}{c}\text { Viscosity } \\
\text { cSt }\end{array}$ \\
\hline 0.915 & 41.25 & 1.76 & 6.89 & 7.53 \\
\hline 0.925 & 154.50 & 6.06 & 5.38 & 5.82 \\
\hline 0.934 & 258.00 & 10.86 & 4.18 & 4.48 \\
\hline 0.942 & 344.00 & 20.06 & 3.44 & 3.65 \\
\hline 0.948 & 414.00 & 29.26 & 2.53 & 2.67 \\
\hline
\end{tabular}

\begin{tabular}{|c|c|c|c|c|}
\hline \multicolumn{3}{|c|}{$\begin{array}{ll}20^{\circ} \mathrm{C} & \text { Tamperature } \\
160.30 \text { psia } & \text { Saturation Pressure }\end{array}$} & \multirow[b]{2}{*}{$\begin{array}{l}\text { Viscosity } \\
\text { cP }\end{array}$} & \multirow[b]{2}{*}{$\begin{array}{l}\text { Viscosity } \\
\text { cSt }\end{array}$} \\
\hline Density & Pressure & $\begin{array}{l}\text { \% Refrig. } \\
\text { Conc. }\end{array}$ & & \\
\hline 0.969 & 22.75 & 3.64 & 48.75 & 50.32 \\
\hline 0.979 & 63.50 & 9.20 & 25.71 & 26.25 \\
\hline 0.989 & 96.50 & 12.39 & 15.55 & 15.72 \\
\hline 1.003 & 132.00 & 20.29 & 9.81 & 9.79 \\
\hline 1.011 & 160.00 & 28.01 & 4.75 & 4.70 \\
\hline
\end{tabular}

\begin{tabular}{|c|c|c|c|c|}
\hline \multicolumn{3}{|c|}{$\begin{array}{ll}60^{\circ} \mathrm{C} & \text { Temperature } \\
417.37 \text { psia } & \text { Saturation Pressure }\end{array}$} & \multirow[b]{2}{*}{$\begin{array}{l}\text { Viscosity } \\
\text { cP }\end{array}$} & \multirow[b]{2}{*}{$\begin{array}{l}\text { Viscosity } \\
\text { cSt }\end{array}$} \\
\hline Density & Pressure & $\begin{array}{l}\text { \% Refrig. } \\
\text { Conc. }\end{array}$ & & \\
\hline 0.941 & 89.00 & 4.58 & 10.28 & 10.92 \\
\hline 0.957 & 168.50 & 10.53 & 7.50 & 7.83 \\
\hline 0.961 & 242.50 & 17.00 & 5.06 & 5.26 \\
\hline 0.972 & 338.50 & 21.19 & 3.35 & 3.45 \\
\hline 0.981 & 417.37 & 30.43 & 1.67 & 1.70 \\
\hline
\end{tabular}

\begin{tabular}{|c|c|c|c|c|}
\hline $\begin{array}{l}0{ }^{\circ} \mathrm{C} \\
89.43 \text { psia }\end{array}$ & $\begin{array}{l}\text { Temperatur } \\
\text { Saturation }\end{array}$ & essure & & \\
\hline Density & Pressure & $\begin{array}{l}\text { * Refrig. } \\
\text { Conc. }\end{array}$ & $\begin{array}{c}\text { Viscosity } \\
c P\end{array}$ & $\begin{array}{c}\text { Viscosity } \\
\text { cSt }\end{array}$ \\
\hline 0.996 & 20.50 & 4.75 & 175.55 & 176.31 \\
\hline 1.001 & 39.75 & 8.97 & 82.31 & 82.22 \\
\hline 1.006 & 57.25 & 11.06 & 58.02 & 57.70 \\
\hline 1.010 & 70.75 & 15.14 & 35.53 & 35.18 \\
\hline 1.015 & 89.43 & 44.98 & 13.62 & 13.41 \\
\hline
\end{tabular}




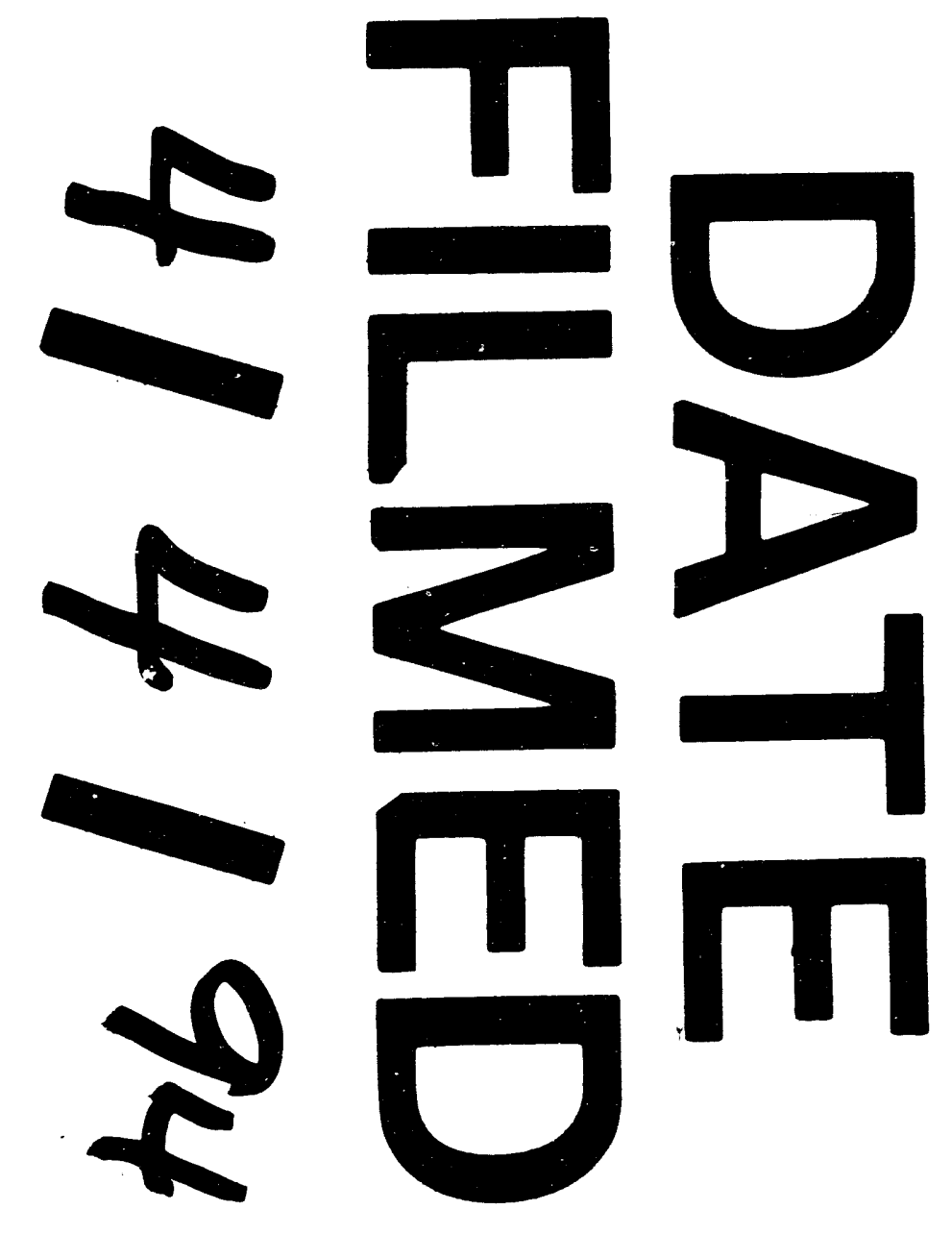




\section{$+\ldots$}

